\title{
Isolation of Industrial Important Bioactive Compounds from Microalgae
}

\author{
Vimala Balasubramaniam ${ }^{1, *} \mathbb{(}$, Rathi Devi-Nair Gunasegavan ${ }^{1} \oplus$, Suraiami Mustar ${ }^{1} \oplus$, June Chelyn Lee ${ }^{2}$ \\ and Mohd Fairulnizal Mohd Noh ${ }^{1}$
}

Citation: Balasubramaniam, V.; Gunasegavan, R.D.; Mustar, S.; Lee, J.C.; Mohd Noh, M.F. Isolation of Industrial Important Bioactive Compounds from Microalgae. Molecules 2021, 26, 943. https: / / doi.org/10.3390/ molecules26040943

Academic Editors:

\section{Ana R. Díaz-Marrero and}

José Javier Fernández Castro

Received: 21 October 2020

Accepted: 5 January 2021

Published: 10 February 2021

Publisher's Note: MDPI stays neutral with regard to jurisdictional clai$\mathrm{ms}$ in published maps and institutional affiliations.

Copyright: () 2021 by the authors. Licensee MDPI, Basel, Switzerland. This article is an open access article distributed under the terms and conditions of the Creative Commons Attribution (CC BY) license (https:// creativecommons.org/licenses/by/ $4.0 /)$.
1 Nutrition, Metabolism \& Cardiovascular Research Centre, Institute for Medical Research, NIH, Level 3, Block C7, No. 1, Jalan Setia Murni U13, Setia Alam, Shah Alam 40170, Malaysia; rathidevinair@moh.gov.my (R.D.-N.G.); suraiami@moh.gov.my (S.M.); fairulnizal@moh.gov.my (M.F.M.N.)

2 Herbal Medicine Research Centre, Institute for Medical Research, NIH, Level 3, Block C7, No. 1, Jalan Setia Murni U13, Setia Alam, Shah Alam 40170, Malaysia; june_lee@moh.gov.my

* Correspondence: vimala.rmt@moh.gov.my

\begin{abstract}
Microalgae are known as a rich source of bioactive compounds which exhibit different biological activities. Increased demand for sustainable biomass for production of important bioactive components with various potential especially therapeutic applications has resulted in noticeable interest in algae. Utilisation of microalgae in multiple scopes has been growing in various industries ranging from harnessing renewable energy to exploitation of high-value products. The focuses of this review are on production and the use of value-added components obtained from microalgae with current and potential application in the pharmaceutical, nutraceutical, cosmeceutical, energy and agrifood industries, as well as for bioremediation. Moreover, this work discusses the advantage, potential new beneficial strains, applications, limitations, research gaps and future prospect of microalgae in industry.
\end{abstract}

Keywords: microalgae; industry; isolation; bioactive compounds; nutraceuticals; pharmaceutical; cosmeceutical

\section{Introduction}

Microalgae are in the form of unicellular, multicellular, filamentous or siphonaceous, known as photosynthetic microorganisms that can be categorized as eukaryotic and prokaryotic [1]. Microalgae are also the largest global primary producers that consist of approximately 200,000 species [2] with distinctive nutrient contents as well as bioactive compounds which have a wide spectrum of commercial applications in various facets of industries including pharmaceuticals, nutraceuticals, cosmeceuticals, biofuels, biofertilisers, wastewater treatments, feed, and proteomics (Figure 1). Production of microalgae involves mass cultivation, recovery of biomass and downstream processes for sustainable yield to cater for food, chemical, feed, biofuel, and high value products. Intrinsic factors such as temperature, salinity, light, and the availability of nutrients affect the chemical composition of the biomasses. Figure 2 illustrates a few of the cultivation processes of microalgae. 


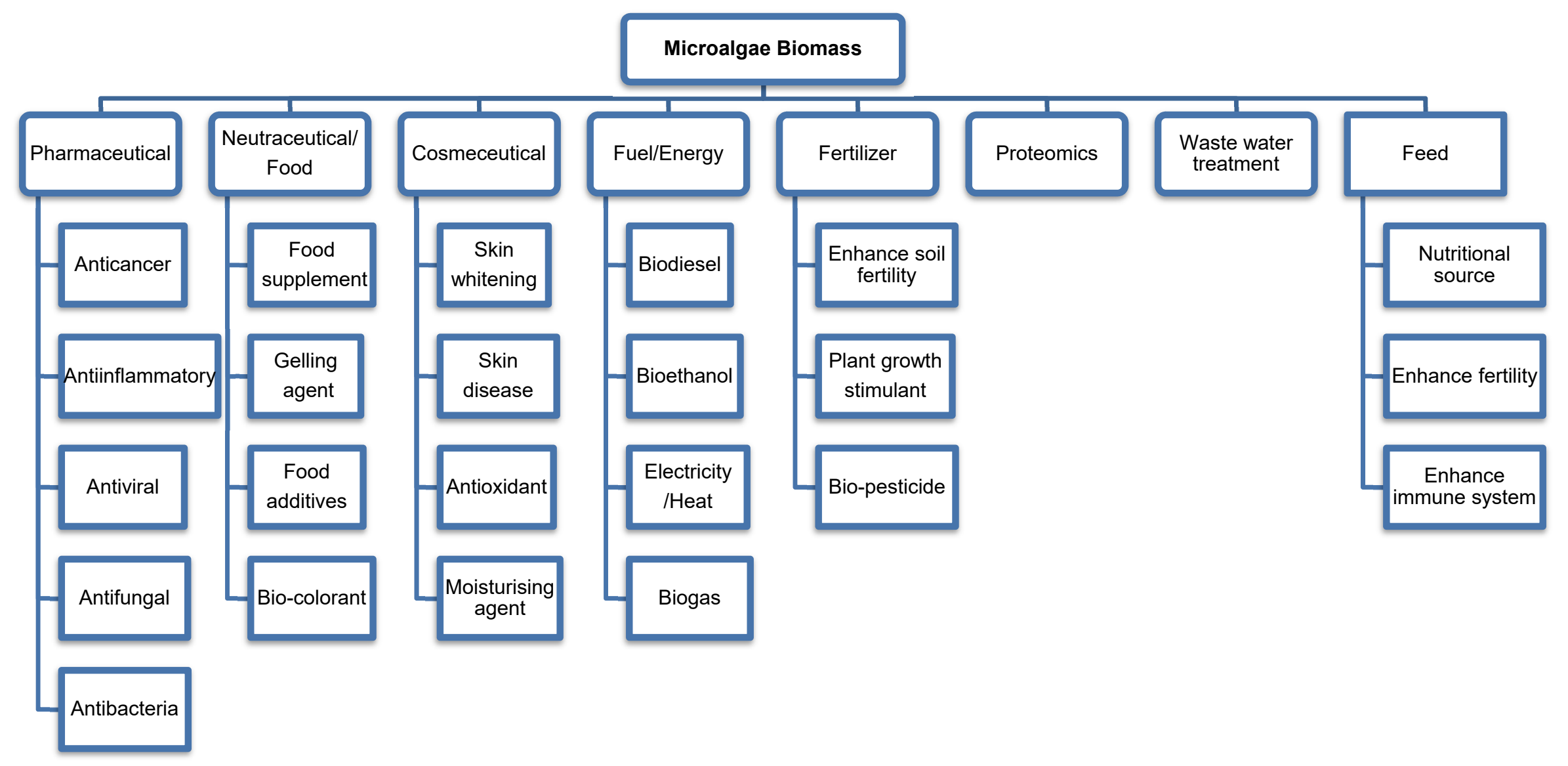

Figure 1. Potential uses of microalgae in various industries. 


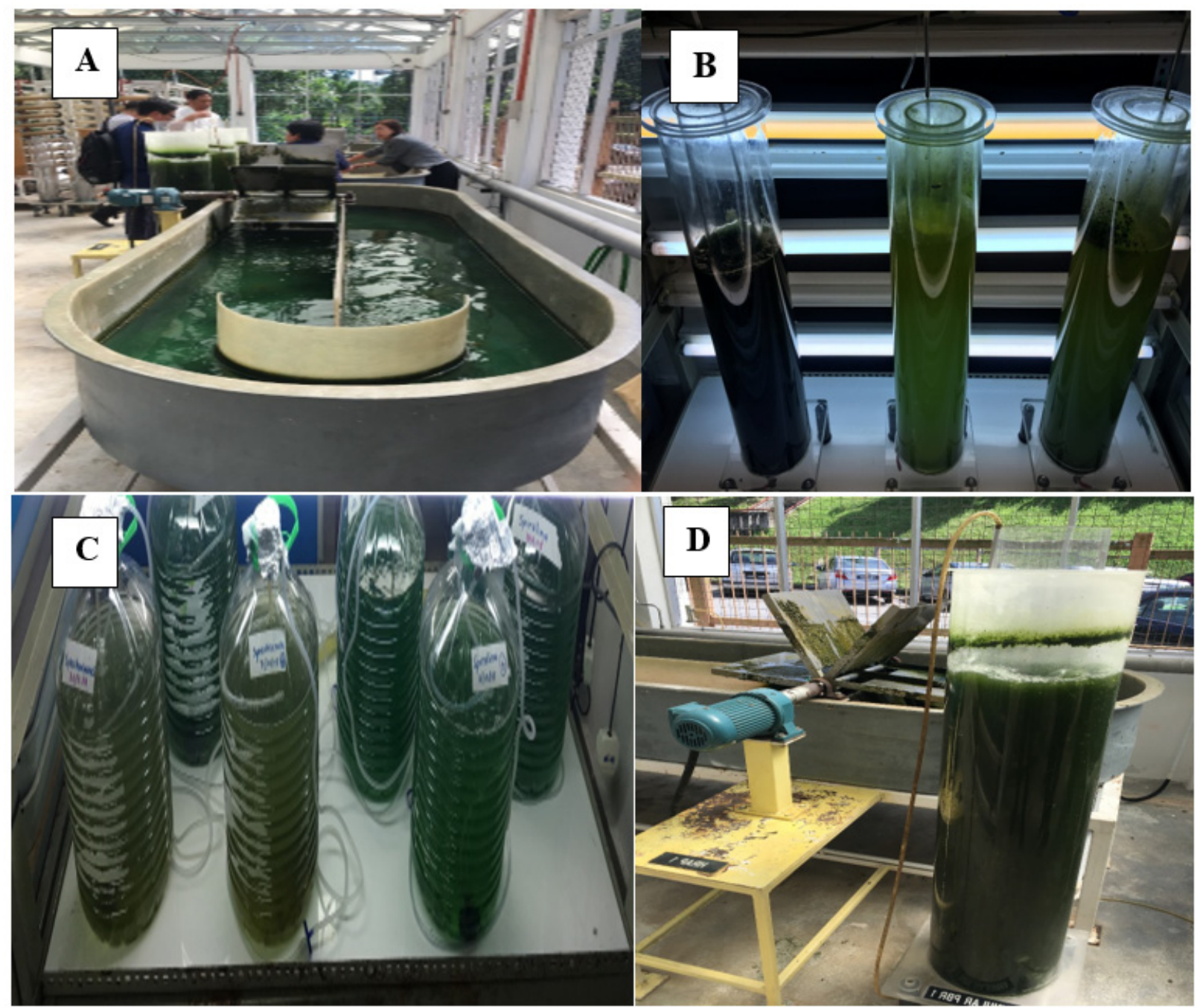

Figure 2. Lab scale microalgae cultivation types. (A) raceway photobioreactor; (B) indoor annular column photobioreactor; (C) microalgae culture in bottles with light and oxygen in Scientific laboratory; (D) open annular photobioreactor (Courtesy: Dr. Adibi Rahiman Md Nor, University Malaya).

The applications of microalgae in industries are concentrated in a few specific species that has high economic value. The highly-sought genera in the global algae market were dominated by Spirulina and Chlorella in the form of dried biomass due to various beneficial health effects [3]. Among the myriad components which were exploited for commercial purpose are fatty acids, carotenoids, vitamin, minerals, polysaccharides, and bioactive compounds. According to the latest analysis, the global market for microalgae is forecasted to reach USD 3318 million by 2022 driven mainly by the demand from pharmaceutical and nutraceutical industries [4] owing to customers' increasing health concern, interest on natural alternatives as well as escalating chronic diseases. Likewise, various microalgae derived compounds were reported to exert various skin benefits which are currently gaining attention in many aspects of cosmeceuticals. Advances of new application areas of microalgae in aquaculture and biofuel production have provided a significant rise of algae demand in the global market. Microalgae are constituted of a high level of lipids. Various research has highlighted the potential of microalgae biomass as a source of renewable energy, namely biofuel which is imperative to reduce the dependency on fossil fuel [5]. Microalgae have an upper hand in the biofuel production compared to other bioenergy sources (corn, sugar cane, palm oil, etc.) as they do not require arable land for cultivation, 
thus eliminating competition for space and resources with food crops. Some of the key players in the algae industries were Algae Tec, Pond Biofuels Incorporated, Cyanotech, Kai BioEnergy, Algae Systems and others [4].

The review aims to summarise the value-added components from microalgae with potential application in the pharmaceutical, nutraceutical, cosmeceutical, energy and agrifood industries, as well as for bioremediation along with commercial applications and examples of microalgal manufacturers as well as commercialized products.

\section{Microalgae Biomass}

The mass production of algae biomass is important for various industries [6]. Numerous methods have been established for microalgae-based products development and down-stream processes with the advancement in the technologies in this area.

\subsection{Biomass Production}

The process of biomass production of microalgae encloses several steps such as cultivation, harvesting and biomass dehydration as shown in Figure 3.

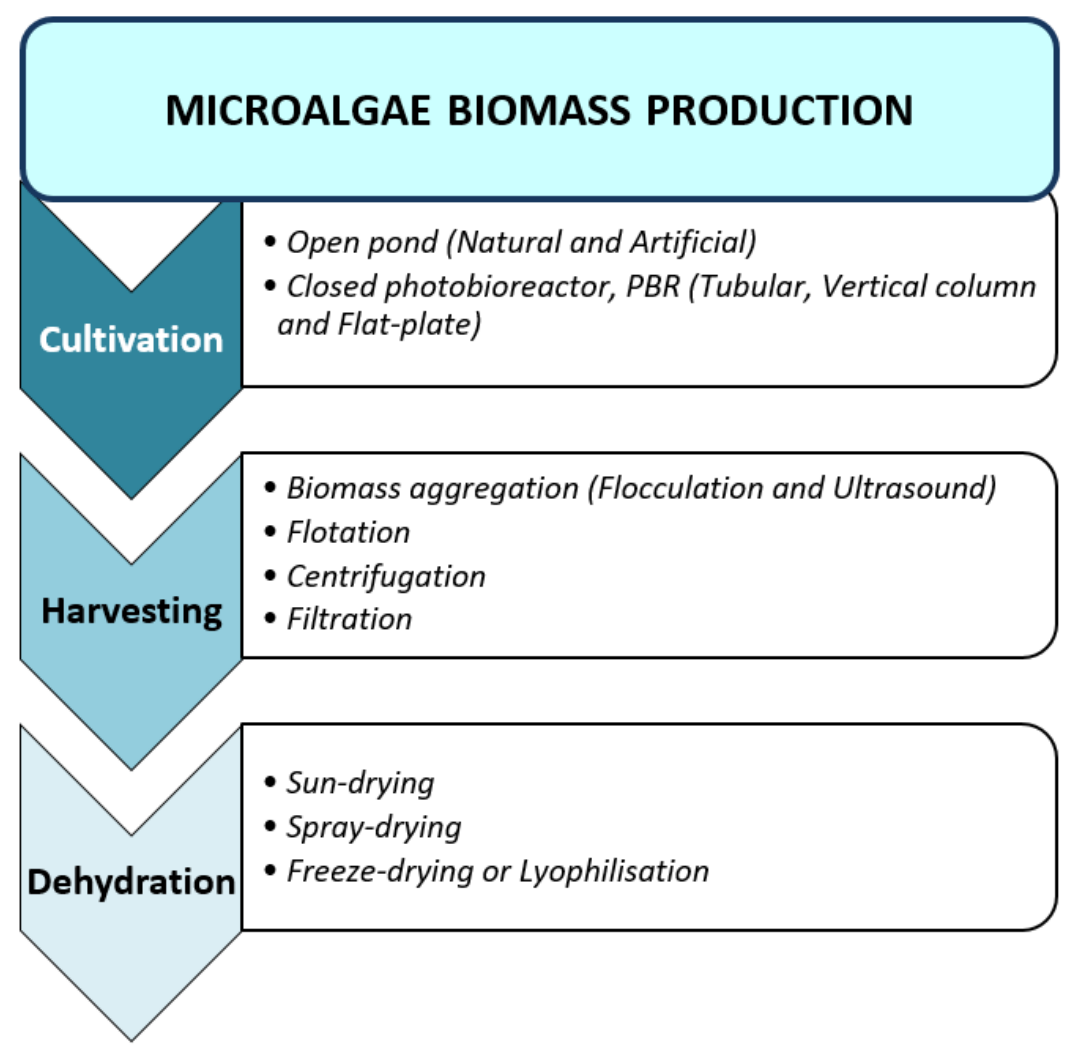

Figure 3. The production of microalgae biomass $[5,6]$.

\subsubsection{Cultivation}

There are two systems developed for the production or culturing of algal biomass: the open pond and closed photobioreactor (PBR) technologies. Open pond production is categorised into two systems: natural waters (ponds, lakes and lagoons) [7] and artificial ponds (circular and raceway) [7,8]. The open pond is a cheaper method of large-scale algal biomass production compared to the PBR. The PBR, however, provide an excellent and controlled closed culture system for cultivation, preventing hazard or contamination from moulds, bacteria, protozoa and competition by other microalgae [9]. It is usually placed outdoors to exploit the free sources of energy from sunlight. There are three types of PBR categorised into tubular (TPBR), vertical column (VCPBR) and flat-plate (FP-PBR) [10]. 


\subsubsection{Harvesting}

The microalga biomass can be separated from the culture medium or harvested by four means: biomass aggregation (flocculation and ultrasound), flotation, centrifugation and filtration. In some cases, combinations of two or more techniques are used to increase effectiveness. The harvesting method selection depends on several criteria of the microalgae such as the density, size and the desired final products [11].

(a) Biomass aggregation: In the flocculation technique, microalgae cells are aggregated together to form a larger particle known as floc, with the addition of flocculants such as multivalent cations and cationic polymers to the media which helped to neutralise the cells surface charge [12]. There are two types of flocculating agents: chemical and bio-flocculants. The cheaper and easily available chemical flocculants that are widely used in industry are iron and aluminium salts [13]. Meanwhile, the common biopolymer bio-flocculants used include acrylic acid and chitosan [14]. In the ultrasound technique, aggregation is initiated followed by increased sedimentation to facilitate harvesting of the algal biomass [15]. The benefit of using this method is that the valuable metabolites are preserved because ultrasonic harvesting does not produce shear stress on the biomass although used continuously [16].

(b) Flotation: It is a technique intended to float algal cells on the surface of the water, using a micro-air bubbles disperser without the addition of chemicals [17]. This technique is economically advantageous due to the low operational costs with an easy operating procedure and high harvesting of biomass [18].

(c) Centrifugation: It is the recovery of algal biomass from the culture media using a centrifuge by gravitational force [19]. This technique is rapid, easy and efficient, but the cost can escalate due to the high energy input and maintenance required [20]. Another disadvantage of this technique is the internal damage of cells, causing a loss of delicate nutrients if a high gravitational force is used [21].

(d) Filtration: It is a process to isolate alga biomass from the liquid culture medium by using a porous membrane with various particle size ranges [22]. It can be implemented through three different ways: conventional, microfiltration and ultrafiltration (isolation of metabolites). The conventional filtration is used to harvest large size microalgae ( $>70$ $\mu \mathrm{m})$ such as Coelastrum and Spirulina. Microfiltration and ultrafiltration are used to harvest smaller size microalgae, equal to the size of the bacteria [23].

\subsubsection{Biomass Dehydration}

Algae biomass is immediately processed to the following stage after being separated from the culture medium to prevent spoilage or to extend their shelf-life [22]. Three different types of drying or dehydration process that are normally used include sun-drying, spray-drying and freeze-drying. The method chosen is entirely dependent on the desired final products:

(a) Sun-drying: It is the cheapest method available compared to the other two techniques. This technique is solely based on the solar energy which causes limitations in terms of weather condition, long drying period and the large drying area needed [24]. Since drying using sunlight is an uncontrollable process, the problem of overheating may occur, change of texture, colour and taste of the microalgae [22].

(b) Spray-drying: This technique is to produce dry powder from a fine spray of suspension droplets which is in continuous contact with hot air in a large vessel. This method has many advantages such as can be operated continuously, the powder produced is very fine and the rapid drying can maintain a good quality product $[25,26]$. This method is usually opted for high-value operations due to its efficiency, but some algal components such as pigments can be significantly deteriorate and the operation cost is expensive [22].

(c) Freeze-drying or Lyophilisation: It is widely used at laboratory-scale only to dry microalgae since large scale production can be very expensive [20]. Freeze-drying is a direct dehydration process of frozen products using sublimation mechanism. The microalgae are frozen to solidify the material within before freeze-drying. The moisture content of the 
microalgae is decreased slowly at low-temperature, maintaining the solid structure and the quality of the product [27].

\subsection{Extraction of Bioactive Compound}

The microalgae are composed of carbohydrates, lipids, proteins, minerals and many other compounds. To utilise the compounds for different application such as for biofuels/energy and agricultural use, the algal biomass will be pre-treated to release the stored bioactive compound in the cells [28]. The cell walls will be lysed to enable all the desired components to be extracted, and this may be accomplished by various ways, such as physical, mechanical (bead milling, homogenisation, microwave, ultrasonic and pulsed electric field), chemical (solvent, acid and alkali) and biological (enzymes) methods. The method chosen for the pre-treatment process is based on the desired final products $[29,30]$.

\section{Microalgae in Pharmaceuticals}

Microalgae are a potential source for bioactive components with pharmaceutical applications. Several important microalgae-derived components with their pharmaceutical applications are highlighted in Table 1. 
Table 1. Important micro-algae derived components in pharmaceutical applications.

\begin{tabular}{|c|c|c|c|c|c|}
\hline Compound & Microalgae Species & Isolation/Extraction Method & $\begin{array}{c}\text { Cell/Virus/Animal Model/Clinical } \\
\text { Patient }\end{array}$ & Effect & References \\
\hline \multicolumn{6}{|c|}{ Anticancer Agents } \\
\hline Lutein & Chlorella vulgaris & $\begin{array}{l}\text { Ethanol extraction and } \\
\text { partitioned with hexane }\end{array}$ & Colon cancer (HCT116) cells & $\begin{array}{c}\text { Antiproliferative effect } \mathrm{IC}_{50}= \\
40.31 \pm 4.43 \mu \mathrm{g} / \mathrm{mL}\end{array}$ & {$[31]$} \\
\hline Violaxanthin & Dunaliella tertiolecta & Dichloromethane extract & $\begin{array}{l}\text { Human mammary carcinoma cell } \\
\text { lines (MCF-7) and human prostatic } \\
\text { carcinoma (LNCaP) cells }\end{array}$ & $\begin{array}{l}\text { Potent inhibition of MCF-7 and LNCaP cells at } \\
\text { growth inhibition }\left(\mathrm{GI}_{50}\right) \text { of } 56.1 \text { and } \\
60.9 \mu \mathrm{g} / \mathrm{mL} \text {, respectively }\end{array}$ & {$[32]$} \\
\hline Fucoxanthin & $\begin{array}{l}\text { Phaeodactylum tricornutum } \\
\text { UTEX } 640\end{array}$ & ressurized liquid extraction & $\begin{array}{l}\text { Human liver cancer cell lines } \\
\text { (Hep-G2), Human colon cancer } \\
\text { (Caco-2) cells and HeLa cell line }\end{array}$ & $\begin{array}{c}\text { An inhibitory effect of up to } 58 \% \text { was } \\
\text { measured in Hep-G2 cells. In HeLa and } \\
\text { Caco- } 2 \text { cells, the effect was stronger than that } \\
\text { of the positive control with a final } \\
\text { concentration of } 5 \% \text { DMSO. }\end{array}$ & [33] \\
\hline Phycocyanin & Spirulina platensis & $\begin{array}{l}\text { Freeze-thawing followed by } \\
\text { solvent extraction }\end{array}$ & $\begin{array}{l}\text { Liver cancer (Hep-G2) cancer cells, } \\
\text { Non-small cell lung cancer (NSCLC) }\end{array}$ & $\begin{array}{c}\text { Inhibited liver cancer cells and leukemia cells. } \\
\text { Induce apoptosis in H460 cells reaching } \\
3.72 \pm 0.98 \% \text { and suppress growth of } \\
\text { NSCLC cells }\end{array}$ & [34-37] \\
\hline Phycocyanin & Spirulina platensis & Supercritical fluid extraction & Human lung cancer cells (A549) & $\mathrm{IC}_{50}=26.82 \mu \mathrm{g} / \mathrm{mL}$ & {$[38]$} \\
\hline Phycocyanin & $\begin{array}{l}\text { Limnothrix sp. } \\
\quad 37-2-1\end{array}$ & $\begin{array}{l}\text { Fractional precipitation and } \\
\text { purification with activated } \\
\text { charcoal and chitosan }\end{array}$ & Prostate Cell Line LNCaP & $\begin{array}{l}\text { C-PC alone }(250 \text { and } 500 \mu \mathrm{g} / \mathrm{mL}) \text { killed } 65 \% \\
\text { and } 70 \% \text { of cells while C-PC }(500 \mu \mathrm{g} / \mathrm{mL}) \\
\text { combined with Topetencan (TPT) }(1 \mu \mathrm{M}) \\
\text { killed } 80 \% \text { of cells due to additive effect }\end{array}$ & [39] \\
\hline Phycocyanin & $\begin{array}{l}\text { Limnothrix sp. } \\
\quad \text { NS01 }\end{array}$ & $\begin{array}{l}\text { Four-step purification } \\
\text { procedure including the } \\
\text { adsorption of impurities with } \\
\text { chitosan, activated charcoal, } \\
\text { ammonium sulfate } \\
\text { precipitation, and } \\
\text { ion-exchange } \\
\text { chromatography }\end{array}$ & $\begin{array}{l}\text { Human breast cancer cell line } \\
\text { (MCF-7) }\end{array}$ & $\begin{array}{c}\mathrm{IC}_{50} \text { for } 24,48 \text { and } 72 \mathrm{~h} \text { exposure to C-PC were } \\
5.92,5.66 \text { and } 4.52 \mu \mathrm{g} / \mu \mathrm{L}\end{array}$ & [40] \\
\hline \multicolumn{6}{|c|}{ Cardioprotective agents } \\
\hline cis $\beta$-carotene & $\begin{array}{l}\text { Dunaliella bardawil } \\
\text { (containing a mixture of cis } \\
\text { and trans-isomers) }\end{array}$ & Enriched extract & Mice fed a high-fat diet & $\begin{array}{l}\text { In old mice with established atherosclerotic } \\
\text { lesion, Dunaliella inhibited significantly } \\
\text { plasma cholesterol elevation and } \\
\text { atherosclerosis progression }\end{array}$ & {$[41]$} \\
\hline $\begin{array}{l}\text { Eicosapentanoic acid } \\
\text { (EPA) }\end{array}$ & Nannochloropsis & Enriched EPA oil & Healthy subjects & Lower cholesterol levels & [42] \\
\hline
\end{tabular}


Table 1. Cont.

\begin{tabular}{|c|c|c|c|c|c|}
\hline Compound & Microalgae Species & Isolation/Extraction Method & $\begin{array}{c}\text { Cell/Virus/Animal Model/Clinical } \\
\text { Patient }\end{array}$ & Effect & References \\
\hline \multicolumn{6}{|c|}{ Antiviral agent } \\
\hline Cyanovirin & Nostoc ellpsosporum & Aqueous extraction & $\begin{array}{c}\text { HIV-1 laboratory strains; } \\
\text { HIV-1 primary isolates; } \\
\text { HIV-2; } \\
\text { SIV; }\end{array}$ & $\begin{array}{l}\text { HIV-1 laboratory strains }\left(\mathrm{EC}_{50} 0.1-5.8 \mathrm{nM}\right) \\
\text { HIV-1 primary isolates }\left(\mathrm{EC}_{50} 1.5-36.8 \mathrm{nM}\right) \\
\text { HIV-2 }\left(\mathrm{EC}_{50} 2.3-7.6 \mathrm{nM}\right), \text { SIV }\left(\mathrm{EC}_{50} 11 \mathrm{nM}\right)\end{array}$ & {$[43]$} \\
\hline Scytovirin & Scytonema varium & Aqueous extraction & $\begin{array}{l}\text { HIV-1 laboratory strain }\left(\mathrm{HIV}-1_{\mathrm{RF}}\right) \\
\text { HIV-1 primary isolates (ROJO) in } \\
\text { peripheral blood mononuclear cell } \\
\text { (PBMC); } \\
\text { HIV-1 primary isolates (Ba-L and } \\
\text { ADA) in macrophages }\end{array}$ & $\begin{array}{c}\text { HIV-1 } 1_{\mathrm{RF}}\left(\mathrm{EC}_{50} 0.3 \mathrm{nM}\right) \\
\text { HIV-1 primary isolates }(\mathrm{ROJO}) \text { in PBMC }\left(\mathrm{EC}_{50}\right. \\
7 \mathrm{nM}), \mathrm{HIV}-1 \text { primary isolates (Ba-L) }\left(\mathrm{EC}_{50}\right. \\
22 \mathrm{nM}), \mathrm{HIV}-1 \text { primary isolates (ADA) }\left(\mathrm{EC}_{50}\right. \\
17 \mathrm{nM})\end{array}$ & {$[44]$} \\
\hline $\begin{array}{l}\text { Mixture of } \\
\text { Icthypeptins A and } \\
\text { Icthypeptins }\end{array}$ & Microcystic ichthyoblabe & Methanol extract & Influenza A & $\mathrm{IC}_{50} 12.5 \mu \mathrm{g} / \mathrm{mL}$ & {$[45]$} \\
\hline Calcium spirulan & Spirulina platensis & Aqueous extraction & $\begin{array}{c}\text { HIV-1; } \\
\text { Herpes simplex virus type } 1 \text { (HSV-1) }\end{array}$ & $\begin{array}{c}\text { HIV-1 }\left(\mathrm{IC}_{50} 9.3 \mu \mathrm{g} / \mathrm{mL}\right) \\
\text { Herpes simplex virus type } 1(\mathrm{HSV}-1)\left(\mathrm{IC}_{50}\right. \\
9.0 \mu \mathrm{g} / \mathrm{mL})\end{array}$ & {$[46]$} \\
\hline
\end{tabular}


Many studies have documented the health benefits of microalgae compounds for prevention and improvement of diseases such as diabetes, obesity, cardiovascular disease, cancer, inflammation, Alzheimer's diseases, depression as well as bacterial, fungal, and viral infections $[38,48,49]$. Despite this, only a limited number of microalgae with pharmaceutical applications are currently available as listed in Table 2. Low extraction yield and high production cost are some of the factors in delaying commercialization of some microalgae-derived bioactives [50]. In addition, there is a potential risk of severe side effects, allergic reactions, and accumulation of heavy metals and toxins in some species of microalgae [51]. Consequently, strong emphasis on the good manufacturing practices in cultivation, harvesting, extracting and purification and controls to limit toxin and impurities are required to ensure safety, efficacy, and quality of microalgae-derived purified compounds and enriched extracts for approval and commercialization [52].

Table 2. Examples of bioactive components from microalgae that are produced on a commercial scale.

\begin{tabular}{|c|c|c|c|c|}
\hline Microalgae & $\begin{array}{l}\text { Bioactive } \\
\text { Component }\end{array}$ & Product & $\begin{array}{l}\text { Pharmaceutical } \\
\text { Applications }\end{array}$ & References \\
\hline $\begin{array}{l}\text { Haematococcus } \\
\text { pluvialis }\end{array}$ & Astaxanthin & $\begin{array}{c}\text { Spirulina (Earth } \\
\text { Spirulina Group, ES } \\
\text { Co, Seoul, Korea) }\end{array}$ & Lipid lowering & [53] \\
\hline $\begin{array}{l}\text { Schizochytrium } \\
\text { limacinum }\end{array}$ & $\begin{array}{l}\text { Docosahexaenoic } \\
\text { acid (DHA) }\end{array}$ & $\begin{array}{c}\text { Maris DHA oil (IOI, } \\
\text { Hamburg, } \\
\text { Germany) }\end{array}$ & $\begin{array}{l}\text { Rheumatoid } \\
\text { arthritis }\end{array}$ & [54] \\
\hline Nannochloropsis & $\begin{array}{l}\text { Eicosapentaenoic } \\
\text { acid (EPA) }\end{array}$ & $\begin{array}{c}\text { Almega }{ }^{\circledR} \mathrm{PL}(\mathrm{iWi} \\
\text { Life) (Qualitas } \\
\text { Health, Houston, } \\
\text { US) }\end{array}$ & $\begin{array}{l}\text { Cholesterol } \\
\text { lowering }\end{array}$ & [42] \\
\hline $\begin{array}{l}\text { Arthrospira } \\
\text { FEM-101 }\end{array}$ & Allophycocyanin & $\begin{array}{c}\text { ApoX surface } \\
\text { antiviral spray } \\
\text { (FEBICO, Taiwan) }\end{array}$ & Antiviral & [55] \\
\hline
\end{tabular}

\subsection{Compounds with Anti-Cancer Properties}

Microalgae-derived bioactives with anti-cancer properties are extensively studied in recent years [52]. Among the compounds, the microalgae pigments such as astaxanthin, $\beta$-carotene, lutein, violaxanthin, and fucoxanthin have the most potential to be commercialized as pharmaceuticals because of their established applications as nutraceuticals and cosmetics and the rising demand as dietary supplements. In fact, astaxanthin and $\beta$ carotene are currently produced commercially from microalgae Dunaliella salina (D. salina) and Hamatococcus pluvialis, respectively, while commercial production of other carotenoids such as lutein and fucoxanthin are gaining momentum [56]. Fucoxanthin, for instance, have been isolated from diatom microalgae Phaeodactylum tricornutum, which is cultivated in a pilot-scale photobioreactor and can be considered as a commercially viable source for fucoxanthin [48]. The anti-cancer properties of some of these carotenoids are summarized in Table 1. Extraction of carotenoid is achieved using ultra-sound extraction and freezethawing methods; however, organic solvent extraction at high temperature and pressure is a more widely used method in commercial-scale production [56].

Another promising anticancer agent is phycocyanin, a protein pigment from the phycobiliprotein group. Phycocyanins are isolated from the commercially grown microalgae Spirulina platensis, but isolation from other cyanobacteria such as Limnothrix sp. has also been reported (Table 1) [38,40]. C-phycocyanin showed inhibitory activity in liver cancer cell lines (HepG2) [34], human leukemia cells (K562) [35] and against lung cancer cell lines (A549 and NSCLC) [36-38]. In another study, the phycocyanin from Limnothrix sp. enhanced the anticancer properties of the anticancer drug Topetecan against the prostate cancer cell line (LNCap) [39]. Meanwhile, phycocyanin isolated from as Limnothrix sp. NS01 with two subunits $\alpha$ and $\beta$ (17 and $20 \mathrm{kDa}$ ) showed antiproliferative activity in human breast cancer cell lines (MCF-7) [40]. Isolation of C-phycocyanin from Spirulina 
platensis was accomplished using buffer ammonium sulfate solution (i.e., salting-out technique) as well as by using supercritical fluid extraction using ethanol as a modifier which resulted in higher yield compared to conventional solvent extraction $[34,38]$. In the studies, impurities were removed using chitosan and activated charcoal however further purified the compound by ion-exchange chromatography was also carried out [40].

\subsection{Compounds with Cardioprotective Properties}

Several microalgae-derived compounds have also been studied for its cardioprotective effect and briefly summarized in Table 1 . Carotenoids are shown to possess antioxidant properties that are important for preventing cell damage caused by free radicals associated with chronic cardiovascular diseases and stroke [57]. In this regard, some microalgae producing a high amount of carotenoids have been investigated for their cardioprotective properties. For instance, D. salina microalgae can produce up to $10-13 \%$ of $\beta$-carotene have been shown to have protective effects against atherosclerosis in both mice and humans. Furthermore, a mixture of tran-isomers $(\sim 40 \%)$ and cis $\beta$-carotene isomers $(\sim 60 \%)$ from $D$. salina was found to be more potent in decreasing total lipid, cholesterol and triglyceride (TG) levels compared to all trans- $\beta$-carotene found in synthetic $\beta$-carotene [58]. Harari et al. [41] also showed that cis $\beta$-carotene isomers $(\sim 50 \%)$ from Dunaliella bardawil powder inhibited atherosclerosis progression in older mice with a high-fat diet. Although cis $\beta$-carotene is still not produced commercially due to its high production costs, a high density inoculum enriched with cis $\beta$-carotene strain from $D$. salina are currently being developed to deliver reproducible, low-cost $D$. salina biomass containing a high content of 9-cis $\beta$-carotene [50].

Another group of bioactive with cardioprotective properties are the polyunsaturated fatty acids (PUFAs), especially the omega- 3 fatty acids such as DHA, EPA and $\alpha$-linoleic acid (ALA) which have been shown to reduce blood cholesterol and improve hypertension. Of these fatty acids, DHA is the only PUFA currently commercially available. Purified EPA sourced from various microalgae including Porphyridium purpureum and Isochrysis galbana are still not economically competitive to be produced commercially. However, a proprietary strain of microalgae Nannochloropsis cultivated in an open pond with high solar radiation was shown to produce high EPA content $(>65 \%)$ oil marketed as A2 EPA Pure ${ }^{\mathrm{TM}}$ for supplement and pharmaceutical applications have been reported [59]. PUFAs are commercially extracted using a hexane solvent followed by mechanical pressing. However, extracted PUFAs are prone to oxidation and therefore all materials that can initiate oxidation such as copper are eliminated from the extraction and storage area [59].

\subsection{Compounds with Antiviral Properties}

Microalgae are also potential sources for bioactives with antiviral properties (Table 2). For example, lectin protein with antiviral properties such as cyanovirin (CV-N) and scytovirin (SVN) have been reported [43,44]. CV-N is a $11 \mathrm{kDa}$ protein consisting of 101 -amino acid in single chain with two disulfide linkages and was isolated from the aqueous extract of Nostoc ellpsosporum and purified by ethanol precipitation followed by fractionation and purification by column chromatography [60]. CV-N showed a broad spectrum of antiviral activity against human immunodeficiency virus-1 (HIV type-1) laboratory and clinical strains with effective concentrations $\left(\mathrm{EC}_{50}\right)$ range $0.1-5.8 \mathrm{nM}$ and $1.5-36.8 \mathrm{nM}$, respectively [43]. In the same study, CV-N was also active against human immunodeficiency virus-2 (HIV-2) and simian immunodeficiency virus with $\mathrm{EC}_{50} 2.3-7.6 \mathrm{nM}$ and $11 \mathrm{nM}$, respectively [43]. Although CV-N showed promising antiviral activity including in an animal HIV transmission model the clinical application of this molecule is currently limited due to its reported mitogenic activity [61]. Meanwhile, another lectin protein SVN has been isolated from the aqueous extracts of cultured cyanobacterium Scytonema varium. SVN is a 9.71 kDa protein consisting of 95-amino acid chains with 5-disulfide linkage which also showed potent antiviral activity against HIV type-1 laboratory strains and clinical isolates with $\mathrm{EC}_{50}$ between 0.3-22 nM [44]. 
Another group of compounds with antiviral activities are the cyclic peptides. The fractions containing a mixture of Icthypeptins A and Icthypeptins B, cyclic depsipeptides isolated from Microcystic ichthyoblabe showed antiviral activity against influenza A virus with inhibitory concentration $\left(\mathrm{IC}_{50}\right)$ of $12.5 \mu \mathrm{g} / \mathrm{mL}$ comparable to the control amantadine $\mathrm{IC}_{50}$ of $15 \mu \mathrm{g} / \mathrm{mL}$ [45]. Besides that, sulfated polysaccharides with antiviral properties have also been described. For example, calcium spirulan isolated from Spirulina platensis showed antiviral activity against $\mathrm{HIV}-1$ with $\mathrm{IC}_{50}$ of $9.3 \mu \mathrm{g} / \mathrm{mL}$ comparable to the dextran sulfate control when assessed by the P24 antigen assay [46]. The sulfated exopolysaccharide $(1 \mu \mathrm{g} / \mathrm{mL})$ from the Spanish strain of Porphyridium cruentum showed a strong inhibitory effect on the cytopathic effect on Herpes simplex virus-1 (HSV-1), Herpes simplex virus-2 (HSV-2) and Vericella virus (VZV) with $\mathrm{CPE}_{50}$ protection of $0.7-5 \mu \mathrm{g} / \mathrm{mL}$ [47].

\section{Microalgae in Nutraceuticals/Food}

A number of microalgae have been classified as Generally Regarded as Safe (GRAS) and approved by the US Food and Drug Administration (FDA). For the guaranteed safety and valuable source of nutrients, algae are used widely in industries especially for food and nutraceutical applications. According to Watanabe [62], microalgae species of cyanobacteria eg. Spirulina, Aphanizomenon and Nostoc are hugely harvested for the food industry. Dried Aphanizomenon contributes approximately 500 tons annually, which is dominantly produced in North America at Upper Klamath Lake, Klamath Falls, Oregon for the food supplement industry, while Spirulina is widely cultured and produced in countries like United States, Taiwan, China, India, and others with an estimated output of 3000 tons annually [63]. The Myanmar Spirulina factory in Yangon produces tablets, chips, pasta, and liquid extract [3]. Other species like Chlorella sp., Haematococcus sp., and Dunaliella sp. cultivated commercially by various countries for nutraceuticals and food application. The list of commercialized strain, industry application, companies, and the countries involved are provided in Table 3. 
Table 3. List of commercialized strain, industry application, companies, and the countries involved.

\begin{tabular}{|c|c|c|c|c|c|}
\hline Biomass & $\begin{array}{c}\text { Extracted } \\
\text { Component }\end{array}$ & Isolation/Extraction Method & Application in Industry & Company & References \\
\hline Spirulina platensis & Algae protein; Biomass & $\begin{array}{l}\text { Enzymatic hydrolysis, Physical } \\
\text { processes, Chemical extraction, } \\
\text { Ultrasound-assisted extraction, } \\
\text { Pulsed electric field, and } \\
\text { Microwave-assisted extraction }\end{array}$ & $\begin{array}{l}\text { Health supplement, } \\
\text { Health food, Infant } \\
\quad \text { formula }\end{array}$ & $\begin{array}{l}\text { Saxony-Anhalt (Germany); } \\
\text { Parry Nutraceuticals (India); } \\
\text { Japan Spirulina Co., Ltd. (Japan); } \\
\text { Siam Alga Co., Ltd. (Thailand) }\end{array}$ & {$[3,64,65]$} \\
\hline Spirulina platensis & Vitamin 12 & Water extraction method & Health supplement & Myanmar Spirulina Factory (Myanmar) & {$[65,66]$} \\
\hline $\begin{array}{l}\text { Chlorella vulgaris } \\
\text { Chorella sp. }\end{array}$ & Biomass, pigments & Microwave-assisted extraction & $\begin{array}{l}\text { Health food, food } \\
\text { supplement }\end{array}$ & $\begin{array}{l}\text { Nikken Sohonsha Corp. (Japan); } \\
\text { Chlorella manufacturing and Co. (Taiwan); } \\
\text { Klötze (Germany); Ocean Nutrition (Canada) }\end{array}$ & {$[3,65]$} \\
\hline Haematococcus pluvialis & Astaxanthin & $\begin{array}{l}\text { Mechanical treatments, chemical } \\
\text { treatments using solvents, } \\
\text { pressurized extraction, ultrasounds } \\
\text { and microwaves }\end{array}$ & $\begin{array}{l}\text { Food supplement, } \\
\text { bio-colorant }\end{array}$ & $\begin{array}{c}\text { Algae Health Science (China); } \\
\text { Cyanotech Corporation (USA); } \\
\text { Aquasearch } \\
\text { Algatechnologies (Israel) }\end{array}$ & {$[65,67-70]$} \\
\hline Dunaliella salina & Beta-carotene & $\begin{array}{l}\text { Solvent extraction; Microwave- } \\
\text { assisted extraction }\end{array}$ & $\begin{array}{l}\text { Health food, Dietary } \\
\text { supplement, bio-colourant }\end{array}$ & $\begin{array}{c}\text { Cyanotech (USA); } \\
\text { Earthrise Nutritionals (USA); } \\
\text { Nature Beta Technologies Cognis (Israel); } \\
\text { Betadene (Australia); } \\
\text { Nature Beta Technologies Cognis (Australia) }\end{array}$ & {$[65,71]$} \\
\hline Ulkenia sp. & DHA & Solvent extraction and microwave & Dietary supplement; & Nutrinova (Germany) & {$[3]$} \\
\hline Schizochytrium sp. & DHA & Cellular hydrolysis & $\begin{array}{l}\text { Dietary supplement; } \\
\text { Health food }\end{array}$ & OmegaTech (USA) & [3] \\
\hline Crypthecodinium cohnii & DHA & Microwave & Infant formula & Martek (USA) & [72] \\
\hline Nannochloropsis oculata & Omega-3 PUFA & $\begin{array}{l}\text { Solvent extraction; } \\
\text { Microwave }\end{array}$ & Omega-3 supplements & $\begin{array}{l}\text { Qualitas (USA); } \\
\text { Cleanalgae SL (Spain); } \\
\text { Astaxa (Germany) }\end{array}$ & {$[73,74]$} \\
\hline Porphyridium spp. & Polysaccharides & Ultrafiltration & $\begin{array}{l}\text { Food additives, } \\
\text { Nutrition }\end{array}$ & InnovalG (France) & {$[65,75,76]$} \\
\hline Euglena gracilis & Biomass & Flocculation & Health food & Euglena (Japan) & [77] \\
\hline Odontella aurita & Fatty acids & & Health supplement & InnovalG (France) & {$[65]$} \\
\hline
\end{tabular}




\subsection{Algal Protein}

Demand for plant-based nutrient especially protein sources has augmented over the years owing to growing health concerns and a shift of millennial preference across the world to nutraceutical products which are convenient and offers a high value of nutrition. This, in turn, has the manufacturers and industries of food and beverages as well as nutraceuticals to search for lucrative sources of protein. Among all, microalgae showed as a promising source of protein combined with diverse bioactive compounds and essential nutrients. The demand for global algae protein exceeded USD 700 million in 2019 and projected to expand over the years in view of changing lifestyle of consumers and preference [78].

Among the myriad of algae, Chlorella and Spirulina species are most sought-after in the global microalgae market owing to its high protein content $(50-70 \%$ protein of its dry weight) and broad spectrum of other nutrients viz. minerals, vitamins, lipids, carbohydrates, pigments and other trace elements [79]. Tavelmout Corp., a biotech company based in Japan developed a closed flat panel photobioreactor system which enhances protein productivity in Spirulina about 20 times higher than that of soybeans [80]. While, Siva Kiran et al. [81] reported that the protein content in Spirulina is higher compared to other foods such as milk, chicken, beef, and some plants. In food application, Spirulina and Chlorella or its protein were incorporated in various types of food, such as milk-based products, bread, biscuits, instant noodles and pasta to produce protein-enriched functional food [82-85].

The extraction of protein from microalgae comprised steps including cell disruption, extraction and product purification; cell disruption techniques involve mechanical action (high-pressure homogenisers, bead mills), ultrasounds, enzymatic or chemical treatments, thermal or osmotic shocks (repeated freezing/thawing) [86]. For efficient protein recovery (76\%) from Chlorella sp., Ursu et al. [87] suggested an alkaline treatment followed by isoelectric precipitation. Meanwhile, Chia et al. [88] proposed an effective approach using ultrasound-assisted three phase partitioning method for efficient protein extraction and an optimised conditions for high protein recovery which is applicable for the future integrated bio-separation technique for biomolecules extraction from microalgae as well as to improve the current downstream bioprocessing techniques.

Chlorella and Spirulina are known for its high-quality protein attributed by the wellbalanced amino acid composition according to FAO/WHO recommendation [89], digestibility coefficient, as well as by its biological value of the amino acids absorbed from the food [90]. Nevertheless, interest to acquire good quality protein for human nutrition continues with exploration on different strains of microalgae, as such, a study on Australian microalgae species in James Cook University/MBD Energy Research facility using Scenedesmus sp., Nannochloropsis sp., Dunaliella sp., and a designed freshwater chlorophytic polyculture (CPC; consisting of Schroederiella apiculata, Scenedesmus pectinatus, Tetraedrom minimum, Mesotaenium sp. and Desmodesmus sp.) exhibited high quality protein in all studied microalgae. The protein was suitable for human consumption which was determined and supported by Essential amino acid index (EAAI) and was comparable to the commercial Spirulina and Chlorella products. The Australian strains earned higher score for EAAI due to presence of higher essential amino acids such as histidine, phenylalanine, threonine and lysine. In addition, the selected strains also displayed a comparable nutrient strength and taste as the Spirulina and Chlorella species respectively, thus, suggesting the potential of these microalgae for future commercialization in human nutrition area [91].

\subsection{Vitamins and Minerals}

Microalgae constitute important source of almost all vitamin and essential minerals. Spirulina was reported as rich source of vitamins $\mathrm{B}_{1}, \mathrm{~B}_{2}, \mathrm{~B}_{12}$ and high content of amino acid up to $62 \%$, [92], all of which have facilitated its claim as superior to other microalgae [93]. Seghiri et al. [92] also suggested that Spirulina benefits may be attributed by the presence of macro-minerals as well as the trace elements. Various studies have shown that Spirulina as a good source of pro-Vitamin A, in term of beta-carotene and exhibited better effects than the synthetic Vitamin A due to its good bioavailability [94,95]. This species also was 
reported for high content of Vitamin $B_{12}$, in the range of 120-244 $\mu$ g per g dry weight, however, studies suggested that most of it were pseudo $B_{12}$, an analogue which has a similar structure and bound to specific $B_{12}$ transporter but does not exert any health benefit $[62,96]$. In contrast, the latest study by Madhubalaji et al. [97], provided a scientific validation for the use of Spirulina as Vitamin $B_{12}$ source. However, more studies needed to substantiate Spirulina as a viable source of Vitamin $B_{12}$ in human. In view of high bioavailability of iron from Spirulina, Puyfoulhoux et al. [98] concluded that Spirulina constitute adequate source of iron for human consumption.

Chlorella is another commercial species with a rich source of proteins, essential amino acids, vitamins (B-complex, ascorbic acid), minerals (potassium, sodium, magnesium, iron, and calcium). Chlorella sp. is suggested to be the best candidate for vegan source of Vitamin $B_{12}$ and used in food supplement [99]. According to Kumudha et al. [66], Vitamin $B_{12}$ detected in the Chlorella vulgaris present as methylcobalamin, a biologically active form suitable for human consumption while Merchant et al. [100] reported that participant supplemented with $9 \mathrm{~g}$ Chlorella pyrenoidosa daily mitigated vitamin $\mathrm{B}_{12}$ deficiency in vegetarian and vegan participants. A study by Nakano et al. [101], suggested $6 \mathrm{~g}$ Chlorella supplementation significantly reduced the risk of pregnancy-associated anaemia, proteinuria and oedema. All of these, suggest microalgae enriched food as a good source of nutritional supplements especially for strict vegetarians owing to its rich high-value nutrients as well as Vitamin $B_{12}$. Chronopoulou et al. [102] proposed an improved approach to extract fat-soluble vitamins by using supercritical $\mathrm{CO}_{2}$ while a previous study compared six extraction methods for Vitamin $B_{12}$ from Spirulina and found the aqueous extraction suits best for this studied compound [103].

\subsection{Fatty Acids}

Microalgae contain distinctive profile of lipids especially the fatty acids, for example, EPA or DHA with feasible commercial value. The ability to produce and accumulate high amount of PUFAs, makes microalgae even more valuable as nutraceutical. Omega-3 fatty acids known as a good source of dietary supplements which highly recognised and recommended for its health benefits specifically in disease prevention [104] and human nutrition. The algal oil often used in liquid or capsule form and benefits in particular, vegetarians as well as populations with low seafood diets. Application of algal oils in food achieved popularity after advancement in the microencapsulation and refining technology which prevents any off-flavour towards the food when combined together with the oils. The algal oils are enriched or fortified in myriad of foods such as dairy products, nutritional bars, bakery products and etc. [105] to further increase product nutritional value.

Microalgae produce total lipid up to $30-70 \%$ of dry weight depending on the species; which plays a critical role as energy stockpile during adverse condition and cell division. Fatty acids are component of complex lipids and the structural variation attributes to their multitudinous benefits. Based on the polarity of the molecular head, fatty acids can be categorised into two groups; (i) neutral lipids and (ii) polar lipids. Fatty acids production can be increased in the microalgae by manipulating various environmental factors such as oxygen level, temperature, light exposure, $\mathrm{pH}$ as well as limiting the nutrient supplementation [106]. A number of studies have suggested nitrogen starvation to increase the neutral lipid and triacylglycerides (TAG) synthesis in microalgae $[107,108]$. Meanwhile, exposure to low light intensity and therefore low temperature was reported to enhance PUFAs production [109,110]. Chlorella sp. culture in low $\mathrm{CO}_{2}$ showed to promote high contents alpha-linolenate fatty acid, in contrast Chlamydomonas reinhardtii mutant cia-3 exhibited higher content of PUFAs in culture condition with high $\mathrm{CO}_{2}$ concentration [111,112].

Methods of harvesting lipid from microalgae include mechanical pressing, homogenization, milling and solvent extraction. The solvent extraction is imperative to the polarity or/and solubility of the lipid of interest. Other techniques such as enzymatic extraction, supercritical extraction, ultrasonic-assisted extraction, microwaves are used to facilitate lipid extraction by solvent [113]. Nevertheless, only a few cell disruption techniques feasi- 
ble for commercial application, namely, steam explosion [114], enzymatic hydrolysis, bead milling and horn sonication [113]. Purification of algal oil (PUFAs) is an essential step as the crude form of these oils are inedible due to its impurities, odour, taste and unattractive for consumption as its turbid appearance. Speed of operation and process condition are critical factors in the oil purification techniques as the oil is sensitive to oxidation. Manufacturer such as Martek Bioscience Corporation has described the oil recovery and purification steps of DHA from algae oil. For instance, protease enzyme was used to break the protein in the cells of Schizochytrium sp. to release the oil into the culture broth forming an emulsion, thereafter isoprophyl alcohol was added to separate the oil. While for Crypthecodinium cohnii, hexane solvent extraction method was applied since the enzyme method is incapable to hydrolyse the algae cellulosic layer. Following the solvent extraction, the cell walls are removed by centrifugation and the oil was recovered after solvent evaporation [115].

Several studies and reviews have been published on the different algae strains, namely, Nannochloropis oculata [73,74], C. cohnii, Schizochytrium sp., Ulkenia sp. which are associated with the presence of high concentration of PUFAs in its lipid [116] and manifested to have better bioavailability compared to other fish oils [74]. These strains have been commercially used to develop high purity marine oils by companies such as Qualitas Health, DSM-NP, Lonza and GCI Nutrients. DHA oil from C. cohnii (40-50\%) are fortified in infant formula milk by company such as Martek, USA, thus, the cultivation and manufacturing processes follow a strict regulation of FDA and current Good Manufacturing Practice (cGMP). This fortified formula sold in more than 60 countries [3]. Recently, two more strains with potential commercial values namely, Phaeodactylum tricornutum and Porphyridium purpureum for EPA and other compounds were suggested [117,118].

\subsection{Natural Pigments}

Microalgae are also a rich source of pigments which are used as bio-colourant or food additives in various products. Natural pigments are highly coveted by food industries as an alternative to synthetic sources which has various health implication [119]. One of the key players in this natural pigment industry is a Chinese astaxanthin supplier, Algae Health Science who operates one of the biggest facilities in the world, using glass tubes to cultivate Haematococcus pluvialis microalgae for astaxanthin extraction in Yunnan, China (Figure 4) [120].
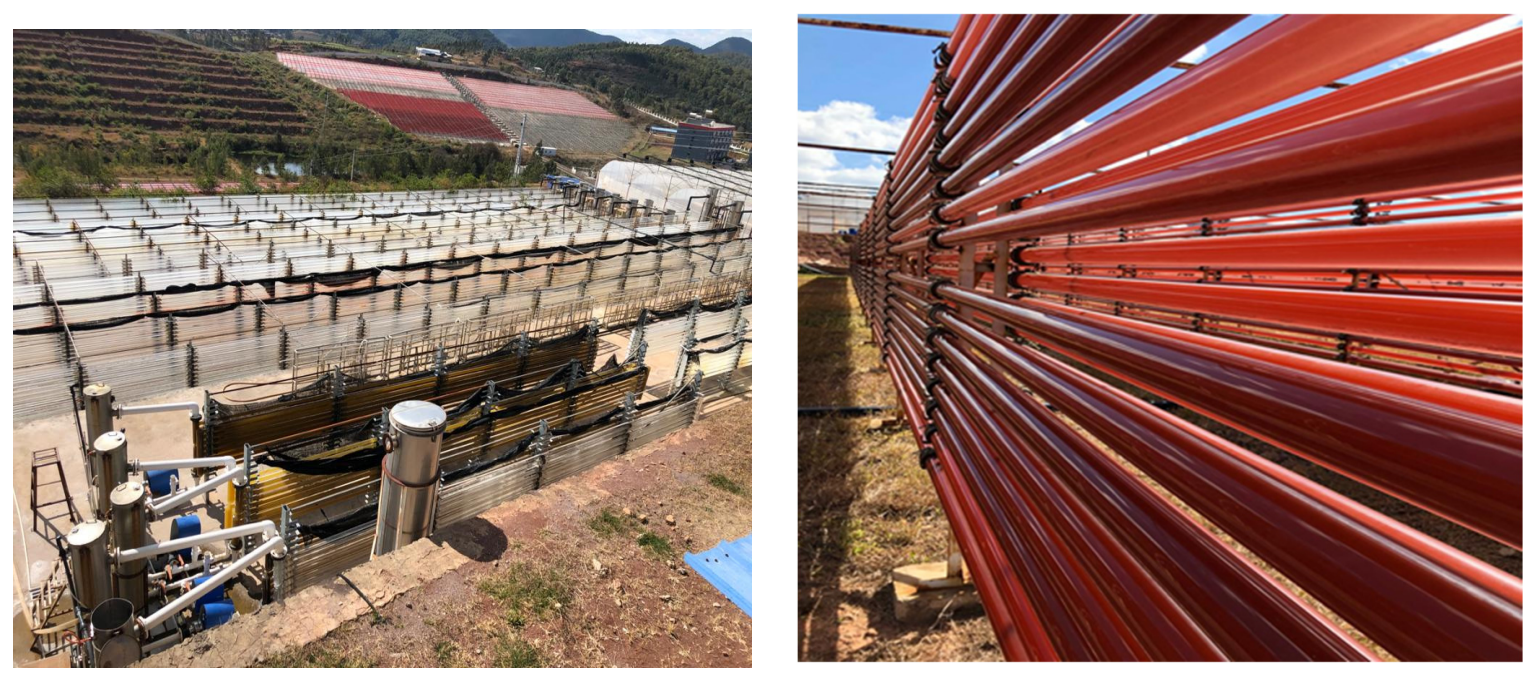

Figure 4. Closed tube bioreactor algae production facility in Yunnan Province, China (Courtesy: Nicholas Cheong, Nova Laboratories Sdn. Bhd.). 
Closed system cultivation was favoured by this company as it provides better purity and prevents contamination, independent of local weather as well as providing consistent production. Astaxanthin from Haematococcus has been marketed under various name and companies, as such Cyanotech Corp. from the US commercialized astaxanthin under the name of BioAstin [121], AstaReal by Fuji Chemical Industry, Japan, Astaxanthin Gold $^{\mathrm{TM}}$ by Nutrigold as well as various patent applications for dietary supplements, health supplements, as antioxidanst, beverage colourants and other functions [122,123].

Chlorophylls, a photosynthetic green pigment present in microalgae as chlorophyll $a$ (blue-green colour), $b$ (brilliant green), $c$ (yellow-green), $d$ (brilliant/forest green) and $\mathrm{f}$ (emerald green) dependent on types of algae [124]. Chlorophyll $a$, which is abundantly found in cyanobacteria such as Chlorella, has been extensively used as colouring agent due to its stability [125]. Another prominent colourant from the microalgae with commercial applications is phycobiliproteins, a water-soluble fluorescent pigment commonly present in cyanobacteria which can be classified as four major groups according to their colours and light absorption characteristics, namely, phycoerythrin, phycocyanin, allophycocyanin and phycoerythrocyanin $[126,127]$. The phycobiliproteins were shown as a strong antioxidant which contributes to high-value nutraceutical product and its application in food mainly in dairy products, chewing gums, candy, beverage mixes and ready-to-eat cereals [128,129]. Besides being a functional ingredient and safe food colourant, this protein (eg. deep blue colour protein C-phycocyanin) are used as dietary supplement coating and functional food additives [85].

Since the global demand of natural colourant especially astaxanthin is growing at an unprecedented rate mainly for food supplements, thus, their average prices in the market are in the range of 2,500 USD per kilograms and its annual worldwide worth of 200 million USD [130]. Species like Dunaliella ascribed to its high beta-carotene contents, contributes a total turnover of about 75 million USD where 60 million from it contributed by food supplements [64].

Many reviews and research papers offer detailed steps on how to improve and enhance related algae cultivation and extraction methods. Development of spiral-tube photobioreactor to cultivate $D$. salina contributes to an enhanced and continuous cultivation for high output of $\beta$-carotene [131]. Additionally, factors such as high light intensity, temperatures, nutrient limitation and high salt concentrations increase the $\beta$-carotene production [132]. A recent study by Xu and Harvey [133], suggested the use of high-intensity red light with sufficient nutrient content for high carotenoid production by up-regulating the whole biosynthesis pathway of carotenoids. Besides its applications as a food colourant, betacarotene is used as an additive in multivitamin supplement and tablets [3].

Harvesting and extraction of certain algal strain can be challenging due to its nature, as such $D$. salina harvesting deemed to be most difficult and costly compared to other commercial strains attributed to its lacking of cell walls, low concentration and small size. Many approved techniques have been developed to tackle the problem such as centrifugation and flocculation, a patented method involving mechanical harvesting [134] while Pirwitz et al. [135] suggested centrifugation without flocculation method which was identified as most cost-effective technique. Other commonly used extraction methods for pigments such as astaxanthin are by mechanical treatments, chemical treatments, pressurized extraction, ultrasound and microwaves among others while a few researches have taken a greener option by using non or less toxic solvents such as acetone and ethanol for the extraction process [68]. Molino et al. [67] suggested a mechanical pre-treatment before accelerated extraction using green solvents.

A continuous search for potential new strains for large-scale production of these pigments are still advancing as the current major strains are still limited to a few species, namely, Spirulina platensis, Haematococcus pluvialis and Chlorella sp. Singh et al. [136] discovered Asterarcys quadricellulare PUMCC 5.1.1 strain, a green microalga with a promising characteristic for carotenoid production while Kaushal et al. [137] reported a new 
cyanobacterium Nodularia sphaerocarpa PUPCCC 420.1 which produces phycobiliprotein and reckoned as a good candidate for production at commercial scale.

\section{Microalgae in Cosmeceuticals}

Skin entity is the largest organ which acts as a physical barrier to protect the human body from harmful external agents, and is composed of three main layers (epidermis, dermis, hypodermis) [138-140]. A healthy and radiant skin is maintained via a balance between synthesis and degradation of the matrix proteins such as collagen, elastin and glycosaminoglycans (hyaluronic acid). The corresponding proteinases coupled with continual synthesis are the maintenance mechanism involved in this process. However, this balance is affected via both chronological as well as photo-ageing by coupling the proteinases upregulation, where this enhances protein degradation along with synthesis down-regulation. Protein synthesis simulation or alteration of their breakdown via proteinases is the suggested mechanism of action for improving this inequality [141].

The synthesis of matrix proteins or proteinases inhibition are attempted with the application of a wide range of specific skin formulation products containing compounds such as ethanolamines, sodium lauryl sulphates, polypeptides or oligopeptides. However, the possibility of developing allergic reactions and other adverse conditions led to continuous search for natural bioactive compounds that could be applied in cosmetic formulations. As such, bioactive compounds originating from microalgae have gained much popularity of its amazing moisturizing, thickening, pigmenting, anti-ageing, skin whitening, sunscreen protection, and many other properties [140,141].

In a review by Mourelle and colleagues, cosmetics are defined as products aimed for improving skin appearance, structure and morphology in assistance of excipients and active ingredients specifically suited for various skin types [142]. Several microalgae species extracts are widely applied in cosmetic-based industries, especially for skincare products. These include face and skincare (anti-ageing cream, emollient, anti-irritant in peelers, refreshing care, sunscreens) as well as hair care products [143]. Among the common microalgae species include Arthrospira sp., C. vulgaris, D. salina, S. platensis, Chondrus crispus, Mastocarpus stellatus, Ascophyllum nodosum, Alaria esculenta and N. oculate [144]. In cosmetic industry, $\mathrm{Cu}-\mathrm{Chl}$ (CI 75810) is applied for use in hair colour products, colour cosmetics and bleaching products and categorised as non-toxic [140]. Figure 5 highlights the main potential applications of various microalgae in cosmetic industry, accounted by its metabolites or bioactive compounds, which are described in detail below.

\subsection{Anti-Ageing}

Ageing is a process that involves a decrease in skin structural proteins (elastin, collagen, hyaluronic acid) synthesis leading to loss in skin elasticity, laxity, integrity and finally gives rise to visible signs of ageing. Apart from decreased protein synthesis, age-dependent down-regulation of skin elasticity is also contributed by an up-regulation of the corresponding proteinases. Hence, the most appropriate anti-ageing strategy in order to attain smooth and healthy skin is by controlling the skin structural constituents' degradation via proteinase activity regulation. In addition, frequent and repetitive exposure to ultraviolet (UV) results in over-production of reactive oxygen species (ROS) that induces oxidative cellular stress and promotes genetic alterations thereby affecting matrix protein structure as well as functions, which eventually results in skin damage. In order to overcome this issue, there is a strong need to scavenge these free radicals [141]. 


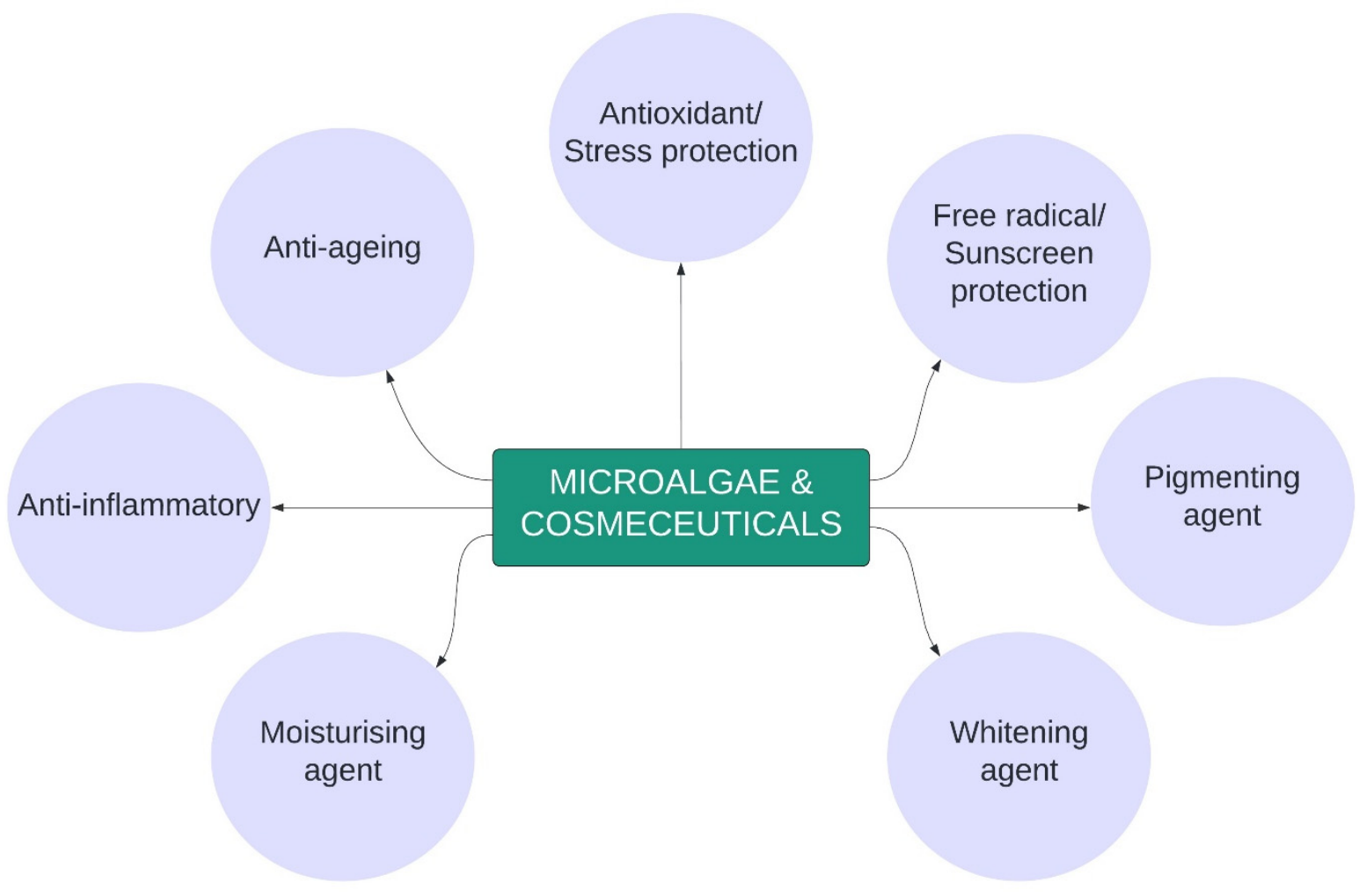

Figure 5. Potential applications of microalgae in cosmeceuticals.

$\beta$-carotene, is one of the microalgae pigments commonly synthesized by $D$. salina that assists in the prevention of free radicals that initiate premature ageing $[140,145,146]$. Another carotenoid compound, lutein is also reported for its protective reactions towards UV radiation and can be obtained from several microalgae (Scenedesmus salina, Chlorella, C. vulgaris, Scenedesmus obliquss, D. salina and Mougeotia sp.) $[140,147]$. Lycopene is also a microalgae carotenoid pigment that is employed in skincare products for its anti-ageing properties where this compound neutralizes oxygen-derived free radicals $[140,142,148]$.

\subsection{Antioxidant/Stress Protection}

Oxidative stress process impacts the skin mainly in terms of premature ageing, uneven skin tone/texture and also might disintegrate the essential proteins. Once the collagen and elastin in the dermal skin layer are diminished via oxidative stress, this also involves significant DNA damage, inflammatory response, reduced antioxidant protection and the generation of matrix metalloprotein. In the long run, this results in expedited ageing process along with significant appearance of wrinkles with loss of elasticity [149]. Fucoxanthin, that is predominantly present in Phaeodactylum tricornotum, Odontella aurita and Isochrysis aff. Galbana is one important metabolite that was identified to portray antioxidant activity as well as preventing oxidative stress. Astaxanthin is reported to possess higher antioxidant activity compared to vitamin A or E, and a recent study by Davinelli and co-workers in the year 2018 highlighted its potential as a potent anti-wrinkle and antioxidant agent [150].

\subsection{Free Radical/Sunscreen Protection}

UV radiation is reported to be beneficial in limited duration; however, prolonged exposure is not advisable as this will result in severe skin damage. In order to prevent these harmful effects, various skincare products are usually applied especially by women that could range from sunscreens, sunblock lotions or anti-ageing serum. Microalgaederived carotenoid pigments such as astaxanthin, lutein, zeaxanthin and canthaxanthin found abundantly within Dunaliella and Haemotococcus sp. are noted for their protective 
properties against extensive sun damages [151]. In addition, orange-pigmented violaxanthin compound isolated from Nannochloropsis oceania is proven to significantly block UVB-detrimental effects along with decreased cell viability and increased ROS production [152]. Fucoxanthin, is another microalgae-derived pigment that has been shown to impart protective effect against sunburn [153].

\subsection{Pigmenting Agent}

Almost all cosmetic products are incorporated with synthetic colourants which attracts much attention of the cosmetic industry towards identifying colourants from natural sources for long-term sustainability. Microalgae pigments fit well into these criteria where it is classified as a naturally sustainable source with added health benefits that include UV protection, anti-ageing, antioxidant and anti-bacterial properties. Carotenoids, chlorophylls and phycobiliproteins encompass the major classes of pigments in microalgae; where they impart various colours ranging from green, yellow, brown and red making it suitable as an alternative to synthetic colourants [154]. Chlorophylls are extensively applied for use as cosmetic colourants, along with its other use in deodorants as an odour-masking agent. Chl a, predominantly found in Chlorella and Spirulina sp. is a blue-green compound and widely used for its stable nature [142]. In contrast to chlorophylls, astaxanthin gives rise to strong red pigmentation, that are highly useful in most cosmetic products [155]. Phycoerythrin exerts intense pink fluorescence and is formulated for use in lipsticks, eye shadow, and other make-up essentials. Phycocyanin, in contrast, imparts blue fluorescence and is sourced from cyanobacteria (Spirulina sp. or Arthrospira sp.). In the Japanese cosmetic market, phycocyanin isolated from Arthrospira sp. has been commercialized as cosmetic colourants and eye shadow products [140].

Apart from being used as colourants, these microalgae-pigments are also utilised in tanning pills. Tanning is a process defined as the skin adaptation to UV exposure whereby the increased melanin level plays role in protecting the skin from sunlight rays that induce free radical formation $[140,156]$. Cantaxanthin, a pigment that is found predominantly in green microalgae (Chlorella sp., Haemotococcus sp. Nannochloropsis sp.) is one of the most common ingredients utilised in tanning pills. Canthaxanthin imparts its tanning effect by darkening the skin via deposition of its red-orange colour in the epidermis and subcutaneous fat. However, it is important to address that canthaxanthin tanning pills are yet to be approved by FDA where adverse effects of urticarial, hepatitis and fatal aplastic anemia have been noticed with daily consumption of these pills [140].

\subsection{Whitening Agent}

In contrast to tanning effect, the favourability towards fairer skin tone especially among Asian women has attracted much interest on whitening products as part of their beauty regime. Whitening effect of skin arises with the inhibition of tyrosinase enzyme, which plays vital role in melanin biosynthesis. Tyrosinase catalyses melanin synthesis via L-tyrosine hydroxylation to 3,4-dihydroxy-L-phenylalanine (L-DOPA) as well as oxidation of L-DOPA to dopaquinone followed by further conversion to melanin [157]. Several microalgal species are noted for their superior tyrosinase inhibition activity, such as $N$. oculate or H. pluvalis. Both zeaxanthin and astaxanthin pigments from these microalgae species are addressed for their anti-tyrosinase ability, making them suitable for cosmetic products intended for skin whitening $[140,158,159]$.

\subsection{Moisturising Agent}

Moisturisation is a very critical step in preventing premature ageing of the skin, by maintaining its elasticity and radiance. The level of moisture retained within the human body is correlated with regulated water transport, corneocytes and hyaluronic acid as well as washing frequency $[160,161]$. In common practice, cosmetic range of products intended for moisturising effect is formulated with hydroxy acid however; this elevates the price range due to its limited supply. As such, microalgae-derived polysaccharides 
are preferred for its abundance as well as environmental-friendly nature. A review by Wang and colleagues highlighted the potential of an extract from Chlorella vulgaris that functions to support skin tissue along with collagen synthesis that assists in reducing wrinkle formation [161].

\subsection{Anti-Inflammatory}

Another vital and challenging issue of cosmetic products lies on the effect of neurogenic inflammation that imparts its implications of irritation and itching as the adverse effects. It is worthwhile to understand that most skin metabolic processes are affected by numerous signals in response to stress-induced brain nervous stimulus [162]. These signals include secretion of different hormones/substances from the various skin cells, such as indicated in Table 4 below.

Table 4. Anti-inflammatory secreted signals of the different skin layers.

\begin{tabular}{ccc}
\hline Skin Cells & Secreted Compounds & Reference \\
\hline Keratinocytes, melanocytes & $\begin{array}{c}\text { Corticotropin-releasing hormone (CRH), } \\
\text { adrenocorticotropic hormone (ACTH), } \\
\text { catecholamines }\end{array}$ & \\
Dermal fibroblasts & ACTH, cortisol, prolactin \\
$\begin{array}{c}\text { Skin nerve endings } \\
\text { Sebaceous glands }\end{array}$ & $\begin{array}{c}\text { Adrenaline, noradrenaline, substance P } \\
\text { CRH, prolactin }\end{array}$ & {$[162-164]$} \\
$\begin{array}{c}\text { Cutaneous nerve endings and } \\
\text { almost all skin cells }\end{array}$ & $\begin{array}{c}\text { Produces and responds to special cytokines } \\
\text { (neurotrophins) }\end{array}$ & {$[162,165,166]$} \\
\hline
\end{tabular}

In response to nervous stress, the neurotrophins signal becomes crucial for some inflammatory process (atopic dermatitis, psoriasis) where it induces proliferation of cutaneous nerve endings along with symptoms ranging from itchiness and pain [162,167,168]. Despite of the limited findings available on microalgae extracts implications on skin disorders, however, there are several bioactive compounds derived from microalgae that are shown to be effective. One such example is of the compound astaxanthin where it is vital in suppressing neuropathic pain in rats; where this involves inhibition of $\mathrm{N}$ methyl-D-aspartate receptors that is also part of pain mechanism caused by neurogenic inflammation $[162,169,170]$.

\subsection{Industrial Applications of Microalgae in Cosmeceuticals}

Microalgae-based products have gained much popularity, and are continuously ventured. Although the marketed products keep increasing over the years, yet it is still under par compared to its active ingredient potential. Most of the products are those focused mainly on antioxidant and photo-ageing protections; where there are still much more to be explored in terms of products intended for skin appendages treatment, modulation of fat adipokines as well as the skin microbiota [162]. At the same time, it is still important to highlight that it is economically disadvantageous in microalgae exploitation as an isolated active compound source due to the relevantly high cost of biomass production as well as purification $[3,162,171,172]$. Despite of these, continual recommendation and exploration to utilise microalgae-derived metabolites for the synthesis of products with multiple uses are inter-related with it being fully natural source along with its numerous benefits especially in cosmetic care $[162,173]$.

In a review by Mourelle and colleagues, it is highlighted that several cosmetic-based industries have invested in establishing their own microalgae cultivation. These include renowned companies such as Louis Vuitton Moët Hennessy (Paris, France), Danial Jouvance (Carnac, France) and AGI Dermatics (America). One of the latest highlighted products in 2020 is the Argan Beta-Retinoid Pink Algae Serum launched by Josie Maran. This product is comprised of the main compound $\beta$-carotene extracted from pink algae that play vital roles to eliminate fine lines, wrinkles, dark spots, dullness, dry and flaky skin. The serum 
is also enriched with organic argan oil, quercetin and is claimed to be free of synthetic colours, fragrance, parabens, petrochemical or phthalates [174]. In addition, various other microalgae-rich extract products are also commercialized on a continual basis. Among these, several products available in the market are as shown in Table 5 below.

Apart from the commercialized products, a recent study in 2017 reported on the potential of a novel, non-fastidious freshwater microalgae (Chlorella emersonii KJ725233) for possible application in cosmeceuticals accounted by its anti-ageing, antioxidant and anti-inflammatory properties. Its ability to inhibit elastase, hyaluronidase, collagenase and to scavenge free radicals supports skin tissue that gives rise to skin rejuvenation. In addition, phytol compounds, shown to reduce the proteinases activity and thus, reduces the dermis inflammation [141]. 
Table 5. Selected representation of the commercialized microalgae-derived cosmetic care products.

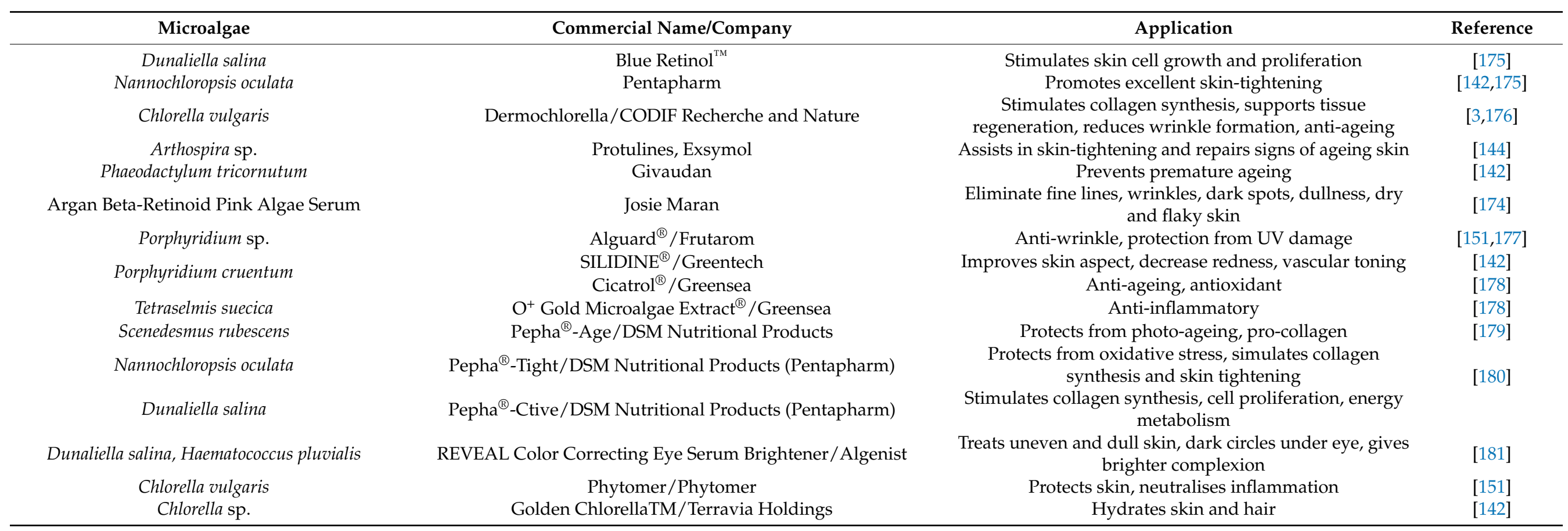




\section{Microalgae in Biofuels and Energy}

Energy production has become the priority of the world's population due to the fuel demand for transportation, electric power generation and operation of manufacturing plants. There are two groups of global energy sources; non-renewable (fossil) and renewable. The renewable energy sources which have been investigated to displace the depleting fossil energy sources include solar, wind, nuclear, geothermal, hydrogen, waves, tidal and algal biomass energy [182,183].

The first generation of biofuels comes from terrestrial crops (e.g., maize, sugarcane, sugar beet and rapeseed) which has many drawbacks/limitations causing destruction of forests and the abundant usage of water. The second generation is from forest residues, lignocellulosic agriculture and from non-food crop feedstocks which disadvantage is the land use $[184,185]$. Biofuels are the renewable energy sources produced from algal biomass which is the third generation of biofuels and is a promising alternative method to the previous methods. The advantages of using algae to generate fuels/energy are that it can be produced all-year-round, easy to cultivate in water without much effort, requires less water compared to terrestrial crops, does not require pesticides or herbicides thus reducing the cultivation cost $[186,187]$.

Alga biofuel has the potential to meet global demand since they do not compete with the production of food products. They can be exploited to biofuels inclusive of biodiesel, bioethanol/biobutanol, syngas, biochar, biogas and energy (electricity/heat) through various processing technologies such as thermochemical conversion (transesterification, thermochemical liquefaction, direct combustion, gasification and pyrolysis) and biochemical conversion (fermentation, anaerobic digestion and photobiological hydrogen production) (Figure 6) [16,188].

\subsection{Biochemical Conversion}

Biochemical conversion is the conversion of microalgae biomass to biofuels with the aid of biocatalysts, such as enzymes and microorganisms such as bacteria and yeast [189]. This method works well with high-water content biomass. The biochemical conversion includes transesterification, fermentation and anaerobic digestion.

\subsubsection{Transesterification-Biodiesel}

Fatty acid methyl ester (FAME) called as biodiesel is produced by transesterification or esterification; a chemical reaction between alcohol and triacylglycerides without or with catalysts such as alkaline catalyst (sodium hydroxide or potassium hydroxide) or acid catalyst (sulphuric, sulphonic, phosphoric, and hydrochloric acids) $[190,191]$. Many species of microalgae such as Scenedesmus obliquus, Neochloris oleabundans, Nannochloropsis $\mathrm{sp}$. and C. vulgaris contain a high content of lipids including triacylglycerides that are needed for the biodiesel production $[192,193]$. The production of biodiesel involves several stages including lipid extraction using solvents; methyl or ethyl alcohol (unrefined lipid), followed by lipid recovery with centrifugation-solvent evaporation (purified lipid and free fatty acids), transesterification or esterification (biodiesel production). The final step of this process is the removal of the solvent for the biodiesel recovery [193]. Biodiesel from renewable resources such as microalgae has several advantages compared to petroleum diesel; non-toxic, biodegradable, renewable and contains low levels of carbon monoxide, soot, hydrocarbons and particulates. It also discharges a low level of $\mathrm{CO}_{2}$ of up to $78 \%$ lower [194]. Many researchers have look into the possibility of producing biodiesel alongside with bioethanol from algae biomass. A study by Wang et al. [195] had shown encouraging results of Tribonema sp. with enriched lipid and carbohydrate content for biodiesel and bioethanol production. The conversion rate of lipid extracted with hexaneethanol to biodiesel was $98.4 \%$ and the maximum yield of ethanol using yeast Saccharomyces cerevisiae was $56.1 \%$. 


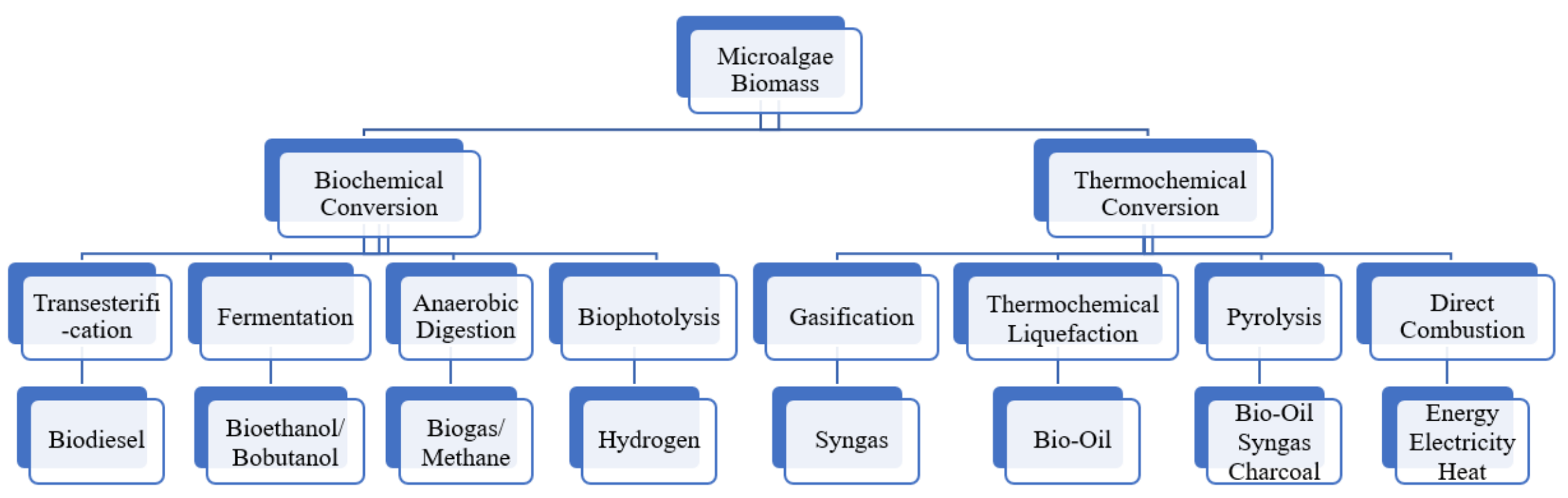

Figure 6. Various methods of producing biofuels/energy from microalgae biomass. Adapted from [16,188]. 


\subsubsection{Fermentation-Bioethanol}

The chemical and enzymatic pre-treatment method are usually used in the production of bioethanol. The common strong acids used include hydrochloric, sulfuric and nitric acid, whereas enzymes such as amylases, cellulases and invertases are used. However, using enzymes can be rather expensive if involves large scale production [196]. Sometimes the cell walls are disrupted using a mechanical method such as by $24 / 24$ freezing/defrosting cycle to release the intracellular substances [197]. The fermentation of the treated biomass is usually using yeast Saccharomyces cerevisiae or bacteria at warm temperature $\left(30-40^{\circ} \mathrm{C}\right)$ to obtain ethanol and a bioreactor is later used for up-scaling $[198,199]$. The quality and quantity of the produced bioethanol are fully determined by the method used and fermentation process parameters inclusive of $\mathrm{pH}$, temperature and the fermenter organism used [200].

Previous studies have shown that several microalgae species can act as an effective feedstock for the production of bioethanol. The species include Chlorococcum humicola, Scenedesmus abundans PKU AC 12, Chlorella vulgaris FSP-E, Scenedesmus obliquus CNW-N, Porphyridium cruentum, Desmodesmus sp., Spirulina platensis and Scenedesmus acuminatus (Refer Table 6). A comparison study of red microalgae (P. cruentum) culture conditions for bioethanol production was done by Kim and co-workers in 2017 [201]. The results indicated ethanol conversion yields from P. cruentum cultured in freshwater was much higher (70.3\%) than the P. cruentum cultured in seawater (65.4\%). Recently, Chandra et al. [202] study the effect of the cultural variables on the carbohydrate accumulation of Scenedesmus acuminatus to produce bioethanol. The bioethanol yield obtained was $0.12 \mathrm{~g} / \mathrm{g}$ with the supplementation of lysine in the medium culture and at higher initial culture $\mathrm{pH}(\mathrm{pH} 9.0)$.

Table 6. Bioethanol production from various microalgae species.

\begin{tabular}{ccc}
\hline Microalgae & $\begin{array}{c}\text { Ethanol Yield } \\
\text { (g Ethanol/g Substrate) }\end{array}$ & Reference \\
\hline Chlorococcum infusionum & 0.26 & {$[203]$} \\
Chlamydomonas reinhardtii & 0.24 & {$[204]$} \\
Chlorococcum humicola & 0.52 & {$[205]$} \\
Scenedesmus abundans PKU AC 12 & 0.103 & {$[206]$} \\
Chlorella vulgaris FSP-E & $11.66(87.59 \%)$ & {$[207]$} \\
Scenedesmus obliquus CNW-N & $8.55(99.8 \%)$ & {$[208]$} \\
Desmodesmus sp. FG & 0.24 & {$[209]$} \\
strain SP2-3 (unidentified green microalga) & 0.12 & {$[202]$} \\
\hline Scenedesmus acuminatus & &
\end{tabular}

\subsubsection{Anaerobic Digestion-Biogas/Methane}

Microalgae can be converted to biogas through anaerobic digestion which is a biochemical process that mineralizes organic material through the action of microorganisms in the absence of oxygen [210]. Biogas is mainly made up of a mixture of methane, $\mathrm{CH}_{4}(50-70 \%)$, $\mathrm{CO}_{2}(30-45 \%)$ and traces of other gases such as hydrogen, $\mathrm{H}_{2}(<2 \%)$ and hydrogen sulphide, $\mathrm{H}_{2} \mathrm{~S}(<3.5 \%)$. The process involves three stages; hydrolysis, acetogenesis/acidogenesis and methanogenesis [211]. Biogas production is often reduced due to the thick and rigid microalgae cell wall, therefore it is normally incorporated with production of other bioproducts such as biodiesel or bioethanol [212]. To overcome the cell wall problems, pre-treatment is usually done to enhance the process. Pre-treatment with heat was found to enhance the production of biomethane from Chlorella sp. by $11 \%$ as the temperature was increased to $90{ }^{\circ} \mathrm{C}$ from $70{ }^{\circ} \mathrm{C}$ for $0.5 \mathrm{~h}$ compared to the control [213].

\subsubsection{Biophotolysis-Hydrogen}

Green microalgae and cyanobacteria can produce hydrogen through biophotolysis process. They possess chlorophyll a and the photosynthetic systems; Photosystem II (PS II) and Photosystem I (PS I), that enables them to perform photosynthesis by absorbing 
solar energy and converting water into hydrogen and oxygen [214,215]. Biophotolysis can be divided into two; direct and indirect pathways. During direct biophotolysis, water splitting at PS II generated electron and proton, giving rise to $\mathrm{H}_{2}$ in both green algae and cyanobacteria. For indirect biophotolysis, the degradation of carbon compounds will generate protons and electrons for the production of hydrogen which are mostly found in cyanobacteria [216].

There are several green microalgae and cyanobacteria such as Tetraspora sp. CU2551, R. rubrum, R. spheroides, Rhodobacter capsulatus, C. vulgaris, C. reinhardtii, Anabaena sp. and Nostoc sp. which have been widely studied for the hydrogen production [217-220]. The model microalga that is usually used for research is the $C$. reinhardtii since some of its organelles such as mitochondrial, nuclear genomes and chloroplast have been successfully sequenced [221].

\subsection{Thermochemical Conversion}

Thermochemical conversion is a process whereby microalgae biomass is converted to biofuels with the involvement of heat at a different temperature depending on the final product desired. This method can be used for both dry and wet biomass. Normally, in the thermochemical conversion no chemicals are added and the period for producing biofuels from this method is shorter than the biochemical conversion [222]. The thermochemical conversion methods include gasification, thermochemical liquefaction, pyrolysis and direct combustion.

\subsubsection{Gasification-Syngas}

Syngas or synthesis gas is mainly composed of methane, hydrogen, carbon monoxide and carbon dioxide that can be used to generate heat or electricity [182,223]. Microalgae biomass is converted to Syngas through a gasification process which utilises partial oxidation with a mixture of oxygen and steam at high temperatures $\left(>700^{\circ} \mathrm{C}\right)$ [224].

\subsubsection{Thermochemical Liquefaction-Bio-Oil}

Crude bio-oil is produced by thermochemical liquefaction in the presence of a catalyst at a temperature between $300-350{ }^{\circ} \mathrm{C}$ [225]. Hydrothermal liquefaction is the preferred method for wet algae biomass which uses water and elevated pressure [224]. The thermochemical liquefaction yield of microalgae depends on various parameters including type of catalysts and reaction temperature [226].

\subsubsection{Pyrolysis-Bio-Oil, Syngas, Charcoal}

Bio-oil, syngas and charcoal can be produced through pyrolysis; the conversion of microalgae biomass in the absence of oxygen at medium to high temperatures $\left(400-600{ }^{\circ} \mathrm{C}\right)$ [227]. Different products produced at different stages of temperature and duration of the process. Bio-oil is produced with a moderate temperature $\left(500^{\circ} \mathrm{C}\right)$ and a short-time exposure to vapour known as flash pyrolysis. Syngas is produced through fast pyrolysis at moderate temperature $\left(500^{\circ} \mathrm{C}\right)$ and moderate time exposure to vapour. Charcoal is produced through slow pyrolysis at a lower temperature $\left(400^{\circ} \mathrm{C}\right)$ and long-time exposure to vapour [228].

\subsubsection{Direct Combustion-Energy (Heat/Electricity)}

Direct combustion is the burning of the microalgae biomass to generate heat, energy or electricity. It is normally done in a boiler or steam turbine at a temperature above $800{ }^{\circ} \mathrm{C}$ in the presence of oxygen. The process can produce $300 \mathrm{MW}$ for domestic or a large-scale industrial process [16]. However, the overall operation cost may increase due to the pre-treatment requires by the microalgae biomass such as drying [229].

\subsection{Industrial Applications of Microalgae in Biofuels}

The potential of microalgae to be used as a source of biofuel in the future to replace the fossil fuel has always been a concerned [230]. However, there are several challenges 
that need to be addressed to enable success which include the development of low-cost, effective cultivation systems, efficient and energy-saving harvesting techniques because there are problems to discard large volumes of water during harvesting and methods for oil extraction and conversion that are environmentally friendly and cost-effective by selecting the best strain for higher production of biofuel $[183,231]$. In terms of cost, the harvesting process may involve a lot of money and commercialization will be too expensive as reported by the U.S. Department of Energy (DOE) who has been doing research in this area for about 16 years from the year 1980s to 1990s [232]. The only oil major company known to be still investing in the microalgae biofuel project is the ExxonMobil. In 2017, after 8 years of collaboration with a biotechnology company Synthetic Genomics, they announced a major breakthrough in producing microalgae with 40 percent more lipids while maintaining growth rates using CRISPRCas9 genome editing technique [233]. However, to date no recent developments are known regarding this issue. Although the microalgae-based biofuel production could not be commercialised in near future, there is still a possibility of using microalgae for biofuels in the future because of the abundance of resources such as the significant amount of land, water and $\mathrm{CO}_{2}$ available to support the algal biofuel technology [232]. Lately, algal biofuel production has attracted interest again from many researchers to explore in this field to be commercialised later. The areas of study and development that need to be considered to achieve success are in the cultivation, harvesting and extraction methods where the growth rate of microalgae need to be enhanced with a more robust alga growing systems, new species/strains with high lipid content need to be sought or the lipid content in the microalgae needs to be enhanced in various ways which are found to be appropriate and the development of an efficient method for the biofuel extraction needs to be explored so as not to increase the production cost [232].

\section{Microalgae in Biofertilisers}

Biofertilisers are natural substances or products containing live microorganisms that enhance the chemical and biological properties of the soils, revive soil fertility and stimulate plants growth [234]. Plants need nitrogen to grow and the lack of such component can be overcome by giving fertiliser at an adequate rate. However, excessive and prolonged use of chemical or synthetic fertilisers resulted in environmental pollution that will eventually cause an imbalance in the ecosystem [235]. As an alternative, microalgae have been extensively studied to see its potential as plant biofertilisers and also biostimulants.

The majority of cyanobacteria can fix nitrogen from the atmosphere and several species are known to be efficient as cyanobacterial-based biofertilisers such as Anabaena sp., Nostoc sp. and Oscillatoria angustissima [236-238]. Some of the various green microalgae and cyanobacteria species successfully used as biofertilisers to enhance crops growth include Acutodesmus dimorphus, S. platensis, C. vulgaris, Scenedesmus dimorphus, Anabaena azolla and Nostoc sp. (Table 7), with Chlorella vulgaris as one of the most commonly used microalgae in biofertiliser studies. The germination of Hibiscus esculentus was accelerated using combined seed and soil treated with $C$. vulgaris. Significant improvement of the soil nutrient content and microorganism count before treatment with the biofertiliser was also observed [239]. 
Table 7. Microalgae species and their use as plant biofertiliser and biostimulant.

\begin{tabular}{ccc}
\hline Microalgae & Crops & Reference \\
\hline Acutodesmus dimorphus & Tomato & {$[240]$} \\
Spirulina platensis, & Maize & {$[241]$} \\
Chlorella vulgaris & Hibiscus esculentus & {$[239]$} \\
Chlorella vulgaris & Rice & {$[242]$} \\
Chlorella vulgaris (UTEX 2714), & & \\
Scenedesmus dimorphus (UTEX 1237) & Onion & {$[243]$} \\
Spirulina platensis, & Tomato and Cucumber seeds & {$[244]$} \\
Chlorella vulgaris & Rice & {$[245]$} \\
Chlorella vulgaris & Rice & {$[246]$} \\
Scenedesmus sp. & Maize & {$[247]$} \\
Anabaena azolla & & \\
Nostoc muscorum & & \\
Nostoc rivulare & &
\end{tabular}

The treatment using green microalgae/cyanobacteria have shown many beneficial effects on the plants and soils. The seed germination, plant growth, yield and the nutritional value of the crops is enhanced besides the improvement of the soil fertility. The carbon and organic content of the soil were accelerated due to the excretion of carbon (exopolysaccharides) by the green microalgae/cyanobacteria into the soil and the degradation of the biomass and grazing activity add on to the increment [248-251]. Studies had shown that those factors influence the microbial activity and biomass of other microflora and fauna in the soil which eventually will stimulate the growth of the crops [248,252].

A study by Bumandalai et al. [244] exhibited the potential of Chlorella vulgaris as biofertiliser for the germination of tomato and cucumber seeds. The length of the tomato and cucumber roots and shoots were improved using algal suspensions of 0.17 and $0.25 \mathrm{~g} / \mathrm{L}$, respectively. Treatment of plants with A. dimorphus biofertiliser before seedling transplant showed enhanced germination, increased production of branches and flowers compared to the control group and the treatment group applied during transplant [240]. Nayak et al. [245] successfully used de-oiled microalgal biomass of Scenedesmus sp. as biofertiliser to improve the growth of rice plant.

The cyanobacteria can colonize different parts of a plant tissue such as in the roots and shoots, stimulating the nitrogen fixation and phosphorus solubilising microbial population on that parts, thus enhancing and improving the growth, nutritional status and defence mechanism of the plant and soil fertility [253-258]. Apart from that, cyanobacteria also produce siderophores (organic compounds) to facilitate in chelating micronutrients (e.g., $\mathrm{Fe}$ and $\mathrm{Cu}$ ), known as biomineralization to make them easily accessible for plants growth [259, 260].

Many green microalgae/cyanobacteria are also reported to excrete intracellular hormones to their surroundings which help to stimulate plants growth [261-263]. Examples are the green microalgae, Chlorophyta and Cyanophyta [264] and some cyanobacteria strains which produce cytokinins and auxins which help to stimulate plants growth parameters such as shoot length, root length, spike length and weight of seeds [265].

The use of green microalgae/cyanobacteria as biofertiliser can increase the activity of defence mechanism of the plants and improve their immunity by increasing the plant RNA activity, producing nutrient assimilating enzymes; dehydrogenase, nitrate reductase, acid or alkaline phosphatase, generating antioxidant and plants defence enzymes such as peroxidase, polyphenol oxidase, phenylalanine ammonia lyase and $\beta-1,3$-endoglucanase in root and shoot of the plants $[256,266,267]$. Different strains of microalgae might provide different levels of defence mechanisms as shown by a study by Babu et al. [268]. Three different cyanobacteria (Anabaena laxa RPAN8, Calothrix sp. and Anabaena sp. CW2) inoculated in wheat plant showed the highest activity of peroxidase, polyphenol oxidase and phenylalanine ammonia-lyase with Calothrix sp. The results could suggest that using a 
combination of different types of microalgae with different abilities as biofertiliser, may contribute to the increase of plants immunity.

Some researchers had tried using a mixture of different microalgae species or a combination of microalgae and other organic or chemical fertilisers to further enhance its effectiveness. Maize plant treated with $C$. vulgaris and S. platensis along with cow dung manure for 75 days under greenhouse conditions, appeared to improve the growth and yield of the maize plant [241]. Jochum et al. [245] utilised a mixed culture of C. vulgaris (UTEX 2714) and Scenedesmus dimorphus (UTEX 1237) biomass as biofertiliser for rice plant. The biofertiliser showed efficacy with a significant increase in height of the rice plant. Growth parameters of onion plants were found to enhance with the application of a mixture of $S$. platensis and C. vulgaris showing higher growth rate and yield compared to the control group [243]. Consortia of green microalgae and cyanobacteria also showed promising results with the improved activity of soil microbial, increase in soil organic carbon, macroand micronutrients and enhanced plant growth and yield $[269,270]$.

\section{Industrial Applications of Microalgae Biofertiliser}

The cost of using chemical fertilisers are increasing every year due to the high demand for foods from plants since it is one of the major important components for plant growth, especially for food production. Microalgae-derived biofertiliser can be an alternative for chemical fertiliser and has gained more popularity due to the natural effects they provide to the crops and the surrounding soil. The chemical fertiliser may cause several problems, among them are the pollution (soil, water, air) to the environment, reducing input efficiency, decreasing food quality, developing resistance in weeds, diseases and insects, micronutrient deficiency in the soil, degradation of soil and causing toxicity effect to different beneficial organisms living in the soil [271]. On the other hand, the biofertilisers are eco-friendly, more economical and more efficient [235]. Several things that are considered before the commercialisation of microalgae as biofertiliser are the formulation of the inoculate, the nature application of the products, packaging issues and also products storage [272] Several countries have successfully commercialised the microalgae-derived biofertiliser products, which include the developing and developed countries. Previously in 2019, a Spanish company, Biorizon Biotech, S.L. had applied a patent for the method of obtaining concentrates of biofertilisers and biostimulants for agricultural use from green microalgae and cyanobacteria biomass [273]. Among the available microalgae-derived biofertiliser products in the market are as shown in Table 8.

Table 8. Commercialised microalgae-derived biofertiliser.

\begin{tabular}{|c|c|c|c|c|}
\hline Microalgae & Commercial Name & Company & Country & Reference \\
\hline $\begin{array}{c}\text { Cyanobacteria } \\
\text { (Blue-green algae) }\end{array}$ & $\begin{array}{c}\text { Skipper Khad }^{\circledR} \text { and } \\
\text { Power Play-90 } \\
\text { WSG }\end{array}$ & $\begin{array}{l}\text { Ecological } \\
\text { Products } \\
\text { Industries }\end{array}$ & India & [274] \\
\hline Spirulina sp. & Shwe Awzar ${ }^{\circledR}$ & $\begin{array}{l}\text { June Industry } \\
\text { Limited }\end{array}$ & Myanmar & [275] \\
\hline Spirulina sp. & Algafert $^{\circledR}$ & Biorizon Biotech & Spain & [276] \\
\hline Chlorella vulgaris & Terradoc $^{\circledR}$ & $\begin{array}{l}\text { Mikroalg Food } \\
\text { and Agriculture } \\
\text { Industries }\end{array}$ & Turkey & [277] \\
\hline Cyanobacteria & TerraSync $^{\mathrm{TM}}$ & $\begin{array}{l}\text { Accelergy } \\
\text { Corporation }\end{array}$ & USA & [278] \\
\hline Chlorella sp. & EMEK & MCT Tarim Ltd. & Turkey & [279] \\
\hline
\end{tabular}

\section{Microalgae in Wastewater Treatment}

Microalgae can utilise nitrogen, phosphorus, carbon and chemicals such as heavy metals from waste water as their source of nutrients and this is called as phycoremediation [280]. Conventional wastewater treatment plants (WWTPs) is designed basically to remove organic matter and nutrients. Nitrogen $(\mathrm{N})$ and Phosphorus $(\mathrm{P})$ are the most impor- 
tant pollutants in the aquatic environments because they are discharged into water bodies in huge quantities. Removal of $\mathrm{N}$ and $\mathrm{P}$ using microalgal remediation technology has high removal efficiencies which $\mathrm{N}$ and $\mathrm{P}$ contaminants can be completely removed from WWTPs, lower costs operation, zero sludge generation and high-value products can be generated such as fatty acids, pigment, biomass, biodiesel and unicellular protein [281-284].

New technology in removing heavy metals such as zinc, copper, lead, mercury, chromium and cadmium from the wastewater (WW) is by using microalgae biomass. Microalgae biomass is an option owing to low obtaining costs and close to $100 \%$ efficiency in the removal of heavy metals $[285,286]$. Microalgae also able to remove colorant such as aniline used by textile, cosmetics and food industries. A major portion of colorant removal is due to the interaction of the molecule with the reactive sites of the cell wall which permits the elimination of the colorant in a rapid manner $[287,288]$.

Emerging contaminants (ECs) are molecules produced in industries such as pharmaceutical (used for human beings and livestock) and chemicals, including compounds such as hormones, antibiotics, plasticizers, antipyretics, antifungal and surfactants which cannot efficiently remove by WWTPs $[289,290]$. The removal of ECs is normally done by physicochemical processes such as photo-oxidation, ozonisation, or oxidation via metallic catalysis. Algae-based bioreactors have gained special research interest as a promising way to remove pharmaceuticals-based ECs from the wastewater either partially or completely. A wide spectrum of technologies has been used for the removal processes for ECs, mainly grouped as physical adsorption, chemical advanced oxidation and biological degradation processes and combination. Laboratory scale (open pond and bubble column photobioreactor) showed high removal percentages have been reached for ciprofloxacin, metoprolol, triclosan, and salicylic acid (>90\%); moderate removal for tramadol and carbamazepine (50-90\%), and trimethoprim and ciprofloxacin show fewer promising results with very low removal $(<10 \%)$ [291].

Based on the latest research, phenol and its derivatives could be metabolized and degraded by algae. The ability of algae to remove phenolic compounds dependant with the type of algae or substrate, degradation time and initial $\mathrm{pH}$. However, algae have a certain tolerance range to phenol [292,293]. Antibiotics are other pollutants that have been released to the environments and create antibiotics resistance. Recently, microalgae-based technology has been explored as a great potential alternative for the treatment of wastewater containing antibiotics by adsorption, accumulation, biodegradation, photodegradation, and hydrolysis [294]. Two freshwater algae species Scenedesmus obliquus and C. pyrenoidosa were shown to have the capability to transform steroids such as progesterone and norgestrel [295].

A device called Microalgae-microbial fuel cell (m-MFC) integrated process has been developed to overcome the problem of fossil-fuel depletion and environmental pollution by generating electrical energy from wastewater and sunlight, wastewater treatment, $\mathrm{CO}_{2}$ sequestration and biomass production in single, self-sustainable technology [296,297]. Table 9 showed microalgae used in the remediation of the pollutants present in the wastewater.

Table 9. Microalgae used in the remediation of the pollutants present in the wastewater.

\begin{tabular}{|c|c|c|}
\hline Pollutants & Microalgae Bioremediation & References \\
\hline Nitrogen \& Phosporus & $\begin{array}{l}\text { Phormidium sp., Spirulina maxima, Chlorella vulgaris, Scenedesmus dimorphus, } \\
\text { Scenedesmus quadricauda, Chlorella sorokiniana, Chlorella vulgaris ESP-6 } \\
\text { Chlorella sp., Tetradesmus sp., Scenedesmus sp., Porphyridium sp., Chaetoceros sp., }\end{array}$ & [281-284] \\
\hline Heavy Metals & $\begin{array}{l}\text { Oscillatoria sp., Sprogyra sp., Scenedesmus sp., Anacytis sp., Chlamydomonas sp., } \\
\text { Anabaena sp., Ceratium sp., Scenedesmus sp., Calothrix sp., Arthrospira platensis }\end{array}$ & {$[285,298,299]$} \\
\hline Colorants & $\begin{array}{c}\text { Chlorella vulgaris, Cosmarium sp., Nostoc linckia, Spirogyra sp. } \\
\text { Emerging Pollutants }\end{array}$ & [300-303] \\
\hline $\begin{array}{l}\text { Antibiotics } \\
\text { Phenol }\end{array}$ & $\begin{array}{c}\text { Nannochloris sp., Mixture of algae-bacteria consortia in pilot high rate algae pond } \\
\text { (HRAP), Mixture of algae-bacteria consortia (dominated by Coelastrum sp.) in } \\
\text { HRAP, Mixture of algae-bacteria consortia in 1-L HRAP S. obliquus, C. vulgaris, } \\
\text { Chlorella sp., Scenedesmus sp., Chlamydomonas mexicana, Chlorella sorokiniana } \\
\text { Chlorella vulgaris } \\
\text { Chlorella pyrenoidosa }\end{array}$ & $\begin{array}{c}{[304-308]} \\
{[293,309]}\end{array}$ \\
\hline
\end{tabular}




\section{Microalgae in Feed}

Microalgae biomass have also been successfully employed in feed formulations for different animals like cattle, fish, goat, lamb, poultry, pigs and rabbits. In aquaculture, species of genus such as Nannochloropsis, Isochrysis, Pavlova, Phaeodactylum, Chaetoceros, Skelotenma, Thalassiosira and Tetraselmis are used as biomass [310]. A microalgae, D. salina has been applied in animal feed for its rich protein $(57 \%$ d.w.) and carbohydrates (32\% d.w.) contents [311]. Microalgal based feed affects the animal's physiology as well as it improves its immune response and fertility. The combination of $5-15 \%$ of algal biomass, mixed with animal feed, can be used safely as a partial replacement for conventional proteins. However, the use of higher concentrations of microalgae biomass results in less feed intake by some animals due to the lower palatability of the feed. The quality of proteins with microalgal sources have a comparable or superior functionality (either as foam, emulsifier, solubilizer, surfactant, or gelling agent) equal or even greater than other commercial protein sources [312]. Chlorella biomass showed that it can be digested easily up to $5 \%$ in the form of paste [44]. Microalgae can provide an important source of essential fatty acid to fish. DHA and EPA are not synthesized by fish and the only resource to enrich them in fish are by accumulating them in proper algal paste and store them as fish feed $[313,314]$. Microalgae, like C. vulgaris and A. platensis, consist of amino acid profiles that show similarities to soybean which is currently the main source of protein used in feed. In addition, the microalgal biomass is a potential source of minerals; C. vulgaris, $A$. platensis, Micractinium reisseri, Nannochloris bacillaris, and Tetracystis sp. showed very high contents of iron in contrast to soybean [315].

\section{Microalgae in Proteomics}

Genetic engineering has been used to manipulate microalgae which allow researchers deducing metabolic pathways in order to construct new algal metabolism methods. This will enable to produce new molecules useful for biotechnological applications [316]. Microalgae proteomics can give the information of how genes of interest are being expressed as proteins which will help researchers to find proteins with biotechnological applications such as anti-inflammatory proteins [317].

The potential of microalgae in the production of proteins with biotechnological application has been explored. C. reinhardtii has been extensively studied for therapeutic protein production and more than 100 such proteins have been expressed successfully in this system [318]. Microalgae-based biomanufacturing is preferred due to effectiveness in terms of cost and energy, fewer contamination chances, and simplified downstream processing. Malaria detection protein which are used in ELISA testing and cell-traversal protein as an antigen from sporozoites and ookinetes of mosquitoes have been successfully expressed and produced in C. reinhardtii chloroplast [319]. Phycobiliproteins from cyanobacteria and red algae have been described to present antioxidant, hepato-protective, anti-inflammatory, immune-modulating, and anticancer effects [48,320-322]. Chlorella pyrenoidosa and Chlorella vulgaris have shown anti-hypertensive and anti-tumour activities from its isolated peptides [322].

A protein isolated from Chlorella sorokiniana has high-value bioactive peptides with nutraceutical and pharmaceutical application, using proteomics techniques [323]. Most of the proteomics approaches in the area of microalgae research are focused in development of efficient biofuels production [324-327].

\section{Conclusions}

Microalgae are promising source of generous amount of metabolites with essential health benefits. Continual exploration for novel microalgae species along with isolation of its bioactive compounds are in great demand for diverse applications in various fields and industries as raw material, biomass or high-quality extracts. Despite of the excellent and superior benefits, there are several limitations that should be addressed as well. The significantly high incurring cost of the isolation might result in over-priced products, where 
it is believed this could be partly subsidised with utilisation of single solvent to generate high extract yield. In addition, it is essentially important to highlight that these are natural extracts with unique composition and varies subject to the season, cultivation condition, as well as the extraction method. Studies are also focusing on extraction of more than one product from a single biomass for a cost-efficient industry. On the other hand, the process of bringing a drug candidate to the market requires extensive pre-clinical testing and clinical trials to determine the safety and efficacy of the drug before it is approved by the FDA and is a very costly and time-consuming process. Hence, not all potential bioactive will eventually reach the market and consumers. Indeed, low yield of bioactive and strenuous and expensive purification steps have been regarded as the main challenge in producing economically viable drugs from microalgae. Therefore, to overcome these issues some of these active compounds are currently expressed in suitable vectors to ease purification and hence reduce the purification and production costs. Efforts on cost reduction by studying effect of different culturing conditions such as light intensity, nutrient availability and harvesting time on the metabolite yield and bioactivity as well as producing high-yield microalgae species via genetic modification approaches are currently pursued to accelerate the commercialization process of some of these bioactives. Meanwhile, advancements in biotechnology applications can help overcome some issues of poor oral bioavailability or instability in the gastrointestinal tract of some microalgae bioactives like peptides and fatty acids. This includes novel approaches using encapsulation technique and nano formulation to improve the solubility and bioavailability of some microalgae derived compounds for treatment of diseases. Furthermore, genetic engineering approaches expressing microalgae metabolites in natural organism for drug delivery have been explored. Nevertheless, more studies especially in in-vivo models and clinical trials are still needed to determine the safety and efficacy of these novel drugs prior to drug approval and commercialization.

In conclusion, it is vital that more efforts should be taken in developing multifunctional range of products, that are affordable and is inter-related with nutritional science that could cater for even more health benefits comparatively to the ones in current market. These findings would bring much more insights into the vast potentials of microalgae-derived metabolites that remain to be explored and assessed. Further roadmap towards enhancing phycoeconomy is recommended by uplifting the current biological and technology process by taking into account on sustainability and environmental benefits.

Author Contributions: Conceptualization: V.B., R.D.-N.G., S.M., J.C.L., M.F.M.N.; Literature review: V.B., R.D.-N.G., S.M., J.C.L., M.F.M.N.; Tables: V.B., R.D.-N.G., S.M., J.C.L., M.F.M.N.; Writing and review: V.B., R.D.-N.G., S.M., J.C.L., M.F.M.N.; Editing: V.B., R.D.-N.G., S.M., J.C.L., M.F.M.N.; Revisions and Final editing: V.B., R.D.-N.G., S.M., J.C.L. All authors have read and agreed to the published version of the manuscript.

Funding: This research received no external funding. The APC was funded by National Institute of Health, Malaysia.

Institutional Review Board Statement: "Not applicable" for studies not involving humans or animals.

Informed Consent Statement: “Not applicable” for studies not involving humans.

Acknowledgments: The authors thank the Director-General of Health Malaysia and the Director of Institute for Medical Research (IMR), National Institutes of Health, Ministry of Health Malaysia, for giving the permission to publish this article. We also thank the staff of Nutrition, Metabolism, and Cardiovascular Centre, Institute for Medical Research, NIH for their continuous support.

Conflicts of Interest: The authors declare no conflict of interest. 


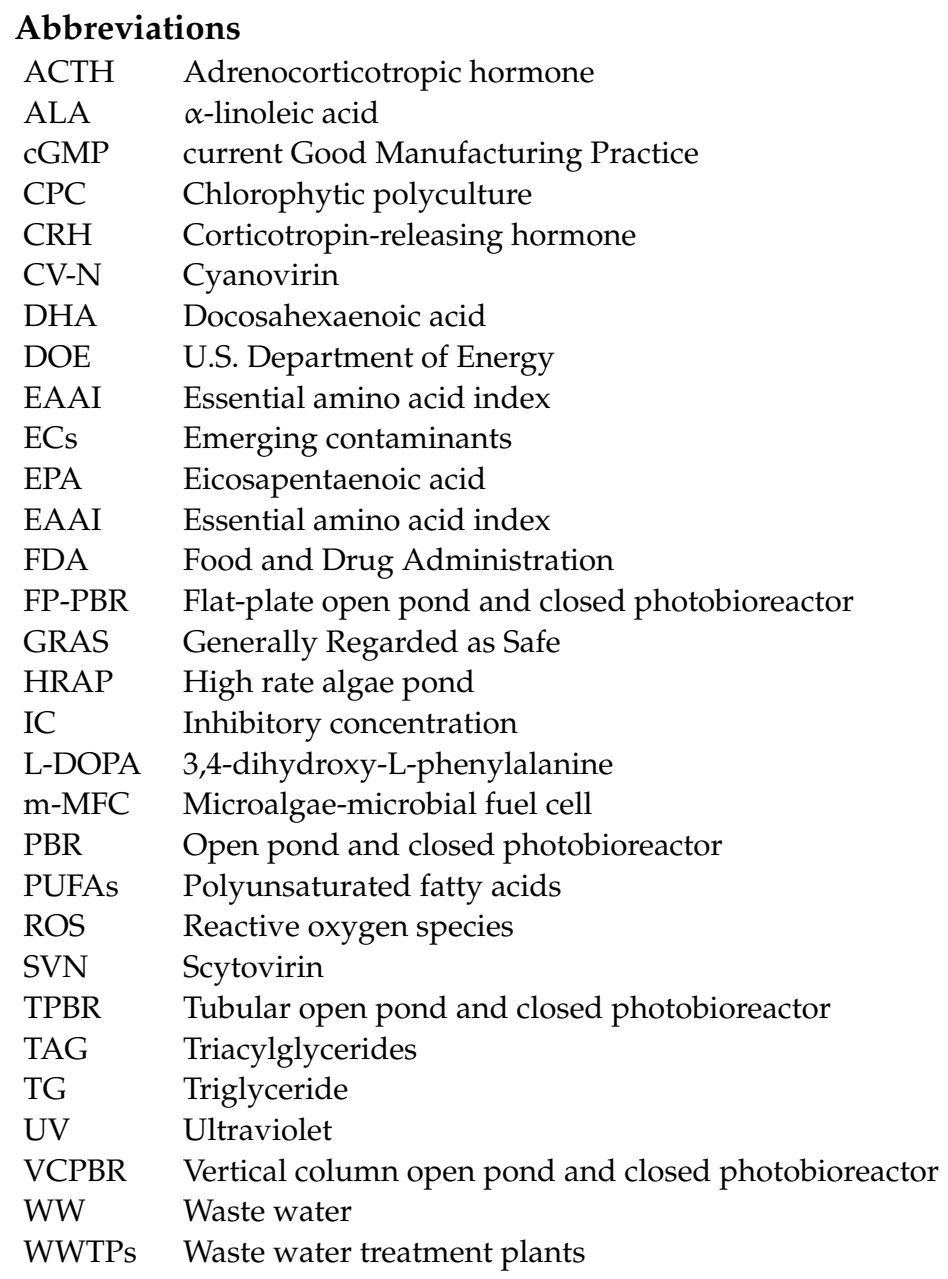

\section{References}

1. Pereira, A.G.; Jimenez-Lopez, C.; Fraga, M.; Lourenço-Lopes, C.; García-Oliveira, P.; Lorenzo, J.M.; Perez-Lamela, C.; Prieto, M.A.; Simal-Gandara, J. Extraction, properties, and applications of bioactive compounds obtained from microalgae. Curr. Pharm. Des. 2020, 26, 1929-1950. [CrossRef] [PubMed]

2. Norton, T.A.; Melkonian, M.; Andersen, R.A. Algal biodiversity. Phycologia 1996, 35, 308-326. [CrossRef]

3. Spolaore, P.; Joannis-Cassan, C.; Duran, E.; Isambert, A. Commercial applications of microalgae. J. Biosci. Bioeng. 2006, 101, 87-96. [CrossRef] [PubMed]

4. Meticulous Research. Algae Products Market by Value (Medium Value, High Value, And Low Value), Products (Hydrocolloids, Carotenoids, Omega-3 PUFA, Spirulina, Chlorella), Application (Food and Feed, Nutraceutical, Cosmetics, Chemicals)—Forecast. 2020. Available online: https://www.meticulousresearch.com/product/algae-products-market-forecast-2022 (accessed on 6 October 2020).

5. Doshi, A.; Pascoe, S.; Coglan, L.; Rainey, T.J. Economic and policy issues in the production of algae-based biofuels: A review. Renew. Sust. Energy Rev. 2016, 64, 329-337. [CrossRef]

6. Benedetti, M.; Vecchi, V.; Barera, S.; Dall'Osto, L. Biomass from microalgae: The potential of domestication towards sustainable biofactories. Microb. Cell Fact. 2018, 17, 1-18. [CrossRef] [PubMed]

7. Sun, Z.; Liu, J.; Zhou, Z.-G. Algae for biofuels: An emerging feedstock. In Handbook of Biofuels Production; Elsevier/Woodhead Publishing: Duxford, UK, 2016; pp. 673-698.

8. Enzing, C.; Ploeg, M.; Barbosa, M.; Sijtsma, L. Microalgae-based products for the food and feed sector: An outlook for Europe. In EUR-Scientific and Technical Research Reports; Vigani, M., Parisi, C., Cerezo, E.R., Eds.; Publications Office of the European Union: Luxembourg, 2014; pp. 9-18.

9. Mendes, L.B.B.; Vermelho, A.B. Allelopathy as a potential strategy to improve microalgae cultivation. Biotechnol. Biofuels 2013, $6,1-14$.

10. Dragone, G.; Fern, B.; Vicente, A.A.; Teixeira, J.A. Third generation biofuels from microalgae. In Current Research, Technology and Educaion Topics in Applied Microbiology and Microbial Biotechnology; Mendez-Vilas, A., Ed.; Formatex Research Center: Badajoz, Spain, 2010; pp. 1355-1366. 
11. Tan, J.S.; Lee, S.Y.; Chew, K.W.; Lam, M.K.; Lim, J.W.; Ho, S.-H.; Show, P.L. A review on microalgae cultivation and harvesting, and their biomass extraction processing using ionic liquids. Bioengineered 2020, 11, 116-129. [CrossRef]

12. Muradov, N.; Taha, M.; Miranda, A.F.; Wrede, D.; Kadali, K.; Gujar, A.; Stevenson, T.; Ball, A.S.; Mouradov, A. Fungal-assisted algal flocculation: Application in wastewater treatment and biofuel production. Biotechnol. Biofuels 2015, 8, 24. [CrossRef]

13. Bracharz, F.; Helmdach, D.; Aschenbrenner, I.; Funck, N.; Wibberg, D.; Winkler, A.; Bohnen, F.; Kalinowski, J.; Mehlmer, N.; Brück, T.B. Harvest of the oleaginous microalgae Scenedesmus obtusiusculus by flocculation from culture based on natural water sources. Front. Bioeng. Biotechnol. 2018, 6, 200. [CrossRef] [PubMed]

14. Pugazhendhi, A.; Shobana, S.; Bakonyi, P.; Nemestóthy, N.; Xia, A.; Kumar, G. A review on chemical mechanism of microalgae flocculation via polymers. Biotechnol. Rep. 2019, 21, e00302. [CrossRef] [PubMed]

15. Bosma, R.; van Spronsen, W.A.; Tramper, J.; Wijffels, R.H. Ultrasound, a new separation technique to harvest microalgae. J. Appl. Phycol. 2003, 15, 143-153. [CrossRef]

16. Brennan, L.; Owende, P. Biofuels from microalgae-A review of technologies for production, processing, and extractions of biofuels and co-products. Renew. Sust. Energy Rev. 2010, 14, 557-577. [CrossRef]

17. Velan, M.; Saravanane, R. Pollution abatement and utilisation of flue gas for bioenergy production-A review. Int. J. Emerg. Technol. Adv. Eng. 2013, 3, 94-99.

18. Alkarawi, M.A.; Caldwell, G.S.; Lee, J.G. Continuous harvesting of microalgae biomass using foam flotation. Algal Res. 2018, 36, 125-138. [CrossRef]

19. Najjar, Y.S.; Abu-Shamleh, A. Harvesting of microalgae by centrifugation for biodiesel production: A review. Algal Res. 2020, 51, 102046. [CrossRef]

20. Grima, E.M.; Belarbi, E.-H.; Fernández, F.A.; Medina, A.R.; Chisti, Y. Recovery of microalgal biomass and metabolites: Process options and economics. Biotechnol. Adv. 2003, 20, 491-515. [CrossRef]

21. Heasman, M.; Diemar, J.; O'Connor, W.; Sushames, T.; Foulkes, L. Development of extended shelf-life microalgae concentrate diets harvested by centrifugation for bivalve molluscs-A summary. Aquac. Res. 2000, 31, 637-659.

22. Show, K.-Y.; Lee, D.-J.; Chang, J.-S. Algal biomass dehydration. Bioresour. Technol. 2013, 135, 720-729. [CrossRef] [PubMed]

23. Gultom, S.O.; Hu, B. Review of microalgae harvesting via co-pelletization with filamentous fungus. Energies 2013, 6, 5921-5939. [CrossRef]

24. De Farias Neves, F.; Demarco, M.; Tribuzi, G. Drying and quality of microalgal powders for human alimentation. In MicroalgaeFrom Physiology to Application; Vítová, M., Ed.; IntechOpen: London, UK, 2019. [CrossRef]

25. Mujumdar, A.S. Classification and selection of industrial dryers. In Mujumdar's Practical Guide to Industrial Drying: Principles, Equipment and New Developments. Brossard, Canada: Exergex Corporation; Sakamon, D., Ed.; Exergex Corporation: Montreal, QC, Canada, 2000; pp. 23-77.

26. Nappa, M.; Teir, S.; Sorsamäki, L.; Karinen, P. Energy Requirements of Microalgae Biomass Production; Technical Report for CCSP Deliverable D606 Espoo 2016; Research Output: Helsinki, Finland, 2016.

27. Oyinloye, T.M.; Yoon, W.B. Effect of freeze-drying on quality and grinding process of food produce: A review. Processes 2020, 8, 354. [CrossRef]

28. Ventura, S.; Nobre, B.; Ertekin, F.; Hayes, M.; Garciá-Vaquero, M.; Vieira, F.; Koc, M.; Gouveia, L.; Aires-Barros, M.; Palavra, A. Extraction of value-added compounds from microalgae. In Microalgae-Based Biofuels and Bioproducts; Elsevier/Woodhead Publishing: Duxford, UK, 2017; pp. 461-483.

29. Günerken, E.; D’Hondt, E.; Eppink, M.; Garcia-Gonzalez, L.; Elst, K.; Wijffels, R.H. Cell disruption for microalgae biorefineries. Biotechnol. Adv. 2015, 33, 243-260. [CrossRef] [PubMed]

30. Velazquez-Lucio, J.; Rodríguez-Jasso, R.M.; Colla, L.M.; Sáenz-Galindo, A.; Cervantes-Cisneros, D.E.; Aguilar, C.N.; Fernandes, B.D.; Ruiz, H.A. Microalgal biomass pretreatment for bioethanol production: A review. Biofuel Res. J. 2018, 5, 780-791. [CrossRef]

31. Cha, K.H.; Koo, S.Y.; Lee, D.-U. Antiproliferative effects of carotenoids extracted from Chlorella ellipsoidea and Chlorella vulgaris on human colon cancer cells. J. Agric. Food Chem. 2008, 56, 10521-10526. [CrossRef] [PubMed]

32. Pasquet, V.; Morisset, P.; Ihammouine, S.; Chepied, A.; Aumailley, L.; Berard, J.-B.; Serive, B.; Kaas, R.; Lanneluc, I.; Thiery, V. Antiproliferative activity of violaxanthin isolated from bioguided fractionation of Dunaliella tertiolecta extracts. Mar. Drugs 2011, 9, 819-831. [CrossRef]

33. Neumann, U.; Derwenskus, F.; Flaiz Flister, V.; Schmid-Staiger, U.; Hirth, T.; Bischoff, S.C. Fucoxanthin, a carotenoid derived from Phaeodactylum tricornutum exerts antiproliferative and antioxidant activities in vitro. Antioxidants 2019, 8, 183. [CrossRef]

34. Prabakaran, G.; Sampathkumar, P.; Kavisri, M.; Moovendhan, M. Extraction and characterization of phycocyanin from Spirulina platensis and evaluation of its anticancer, antidiabetic and antiinflammatory effect. Int. J. Biol. Macromol. 2020, 153, $256-263$. [CrossRef]

35. Liu, Y.; Xu, L.; Cheng, N.; Lin, L.; Zhang, C. Inhibitory effect of phycocyanin from Spirulina platensis on the growth of human leukemia K562 cells. J. Appl. Phycol. 2000, 12, 125-130. [CrossRef]

36. Hao, S.; Yan, Y.; Li, S.; Zhao, L.; Zhang, C.; Liu, L.; Wang, C. The in vitro anti-tumor activity of phycocyanin against non-small cell lung cancer cells. Mar. Drugs 2018, 16, 178. [CrossRef]

37. Hao, S.; Li, S.; Wang, J.; Yan, Y.; Ai, X.; Zhang, J.; Ren, Y.; Wu, T.; Liu, L.; Wang, C. Phycocyanin exerts anti-proliferative effects through down-regulating TIRAP/NF-kB activity in human non-small cell lung cancer cells. Cells 2019, 8, 588. [CrossRef] 
38. Deniz, I.; Ozen, M.O.; Yesil-Celiktas, O. Supercritical fluid extraction of phycocyanin and investigation of cytotoxicity on human lung cancer cells. J. Supercrit. Fluids 2016, 108, 13-18. [CrossRef]

39. Gantar, M.; Dhandayuthapani, S.; Rathinavelu, A. Phycocyanin induces apoptosis and enhances the effect of topotecan on prostate cell line LNCaP. J. Med. Food 2012, 15, 1091-1095. [CrossRef]

40. Safaei, M.; Maleki, H.; Soleimanpour, H.; Norouzy, A.; Zahiri, H.; Vali, H.; Noghabi, K. Development of a novel method for the purification of C-phycocyanin pigment from a local cyanobacterial strain Limnothrix sp. NS01 and evaluation of its anticancer properties. Sci. Rep. 2019, 9, 9474. [CrossRef] [PubMed]

41. Harari, A.; Abecassis, R.; Relevi, N.; Levi, Z.; Ben-Amotz, A.; Kamari, Y.; Harats, D.; Shaish, A. Prevention of atherosclerosis progression by 9-cis- $\beta$-carotene rich alga Dunaliella in apoE-deficient mice. BioMed Res. Int. 2013, 2013. [CrossRef] [PubMed]

42. Rao, A.; Briskey, D.; Nalley, J.O.; Ganuza, E. Omega-3 eicosapentaenoic acid (EPA) rich extract from the microalga nannochloropsis decreases cholesterol in healthy individuals: A double-blind, randomized, placebo-controlled, three-month supplementation study. Nutrients 2020, 12, 1869. [CrossRef] [PubMed]

43. Boyd, M.R.; Gustafson, K.R.; McMahon, J.B.; Shoemaker, R.H.; O’Keefe, B.R.; Mori, T.; Gulakowski, R.J.; Wu, L.; Rivera, M.I.; Laurencot, C.M. Discovery of cyanovirin-N, a novel human immunodeficiency virus-inactivating protein that binds viral surface envelope glycoprotein gp120: Potential applications to microbicide development. Antimicrob. Agents Chemother. 1997, 41, 1521-1530. [CrossRef]

44. Bokesch, H.R.; O’Keefe, B.R.; McKee, T.C.; Pannell, L.K.; Patterson, G.M.; Gardella, R.S.; Sowder, R.C.; Turpin, J.; Watson, K.; Buckheit, R.W. A potent novel anti-HIV protein from the cultured cyanobacterium Scytonema varium. Biochemistry 2003, 42, 2578-2584. [CrossRef] [PubMed]

45. Zainuddin, E.N.; Mentel, R.; Wray, V.; Jansen, R.; Nimtz, M.; Lalk, M.; Mundt, S. Cyclic depsipeptides, ichthyopeptins A and B, from Microcystis ichthyoblabe. J. Nat. Prod. 2007, 70, 1084-1088. [CrossRef]

46. Hayashi, K.; Hayashi, T.; Kojima, I. A natural sulfated polysaccharide, calcium spirulan, isolated from Spirulina platensis: In vitro and ex vivo evaluation of anti-herpes simplex virus and anti-human immunodeficiency virus activities. AIDS Res. Hum. Retrovir. 1996, 12, 1463-1471. [CrossRef]

47. Huleihel, M.; Ishanu, V.; Tal, J.; Arad, S.M. Antiviral effect of red microalgal polysaccharides on Herpes simplex and Varicella zoster viruses. J. Appl. Phycol. 2001, 13, 127-134. [CrossRef]

48. Talero, E.; García-Mauriño, S.; Ávila-Román, J.; Rodríguez-Luna, A.; Alcaide, A.; Motilva, V. Bioactive compounds isolated from microalgae in chronic inflammation and cancer. Mar. Drugs 2015, 13, 6152-6209. [CrossRef]

49. Rumin, J.; Nicolau, E.; Junior, R.G.D.O.; Fuentes-Grünewald, C.; Picot, L. Analysis of scientific research driving microalgae market opportunities in Europe. Mar. Drugs 2020, 18, 264. [CrossRef] [PubMed]

50. Harvey, P.J.; Ben-Amotz, A. Towards a sustainable Dunaliella salina microalgal biorefinery for 9-cis $\beta$-carotene production. Algal Res. 2020, 50, 102002. [CrossRef]

51. Gilroy, D.J.; Kauffman, K.W.; Hall, R.A.; Huang, X.; Chu, F.S. Assessing potential health risks from microcystin toxins in blue-green algae dietary supplements. Environ. Health Perspect. 2000, 108, 435-439. [CrossRef] [PubMed]

52. Martínez Andrade, K.A.; Lauritano, C.; Romano, G.; Ianora, A. Marine microalgae with anti-cancer properties. Mar. Drugs 2018, 16, 165. [CrossRef]

53. Park, H.J.; Lee, Y.J.; Ryu, H.K.; Kim, M.H.; Chung, H.W.; Kim, W.Y. A randomized double-blind, placebo-controlled study to establish the effects of spirulina in elderly Koreans. Ann. Nutr. Metab. 2008, 52, 322-328. [CrossRef] [PubMed]

54. Dawczynski, C.; Dittrich, M.; Neumann, T.; Goetze, K.; Welzel, A.; Oelzner, P.; Völker, S.; Schaible, A.; Troisi, F.; Thomas, L. Docosahexaenoic acid in the treatment of rheumatoid arthritis: A double-blind, placebo-controlled, randomized cross-over study with microalgae vs. sunflower oil. Clin. Nutr. 2018, 37, 494-504. [CrossRef]

55. FEBICO. ApoX Surface Anti-Viral Spray. Available online: https://www.febico.com/en/product/Spray.html (accessed on 8 October 2020).

56. Novoveská, L.; Ross, M.E.; Stanley, M.S.; Pradelles, R.; Wasiolek, V.; Sassi, J.-F. Microalgal carotenoids: A Review of production, current markets, regulations, and future direction. Mar. Drugs 2019, 17, 640. [CrossRef]

57. Raposo, M.F.D.J.; de Morais, A.M.M.B.; de Morais, R.M.S.C. Carotenoids from marine microalgae: A valuable natural source for the prevention of chronic diseases. Mar. Drugs 2015, 13, 5128-5155. [CrossRef]

58. Raposo, M.F.D.J.; de Morais, A.M.M.B. Microalgae for the prevention of cardiovascular disease and stroke. Life Sci. 2015, 125, 32-41. [CrossRef]

59. Winwood, R.J. Recent developments in the commercial production of DHA and EPA rich oils from micro-algae. OCL 2013, 20, D604. [CrossRef]

60. Gustafson, K.R.; Sowder, R.C.; Henderson, L.E.; Cardellina, J.H.; McMahon, J.B.; Rajamani, U.; Pannell, L.K.; Boyd, M.R. Isolation, primary sequence determination, and disulfide bond structure of cyanovirin-N, an anti-HIV (human immunodeficiency virus) protein from the CyanobacteriumNostoc ellipsosporum. Biochem. Biophys. Res. Commun. 1997, 238, 223-228. [CrossRef] [PubMed]

61. Huskens, D.; Schols, D. Algal lectins as potential HIV microbicide candidates. Mar. Drugs 2012, 10, 1476-1497. [CrossRef]

62. Watanabe, F. Vitamin $B_{12}$ sources and bioavailability. Exp. Biol. Med. 2007, 232, 1266-1274. [CrossRef] [PubMed]

63. Bishop, W.; Zubeck, H. Evaluation of microalgae for use as nutraceuticals and nutritional supplements. J. Nutr. Food Sci. 2012, 2, 1-6. [CrossRef] 
64. Bioeconomy BW. Microalgae Can Produce More than Just Fuel. Available online: https://www.biooekonomie-bw.de/en/ articles/news/microalgae-can-produce-more-than-just-fuel (accessed on 10 September 2020).

65. Pulz, O.; Gross, W. Valuable products from biotechnology of microalgae. Appl. Microbiol. Biotechnol. 2004, 65, 635-648. [CrossRef] [PubMed]

66. Kumudha, A.; Selvakumar, S.; Dilshad, P.; Vaidyanathan, G.; Thakur, M.S.; Sarada, R. Methylcobalamin-A form of vitamin B12 identified and characterised in Chlorella vulgaris. Food Chem. 2015, 170, 316-320. [CrossRef]

67. Molino, A.; Rimauro, J.; Casella, P.; Cerbone, A.; Larocca, V.; Chianese, S.; Karatza, D.; Mehariya, S.; Ferraro, A.; Hristoforou, E. Extraction of astaxanthin from microalga Haematococcus pluvialis in red phase by using generally recognised as safe solvents and accelerated extraction. J. Biotechnol. 2018, 283, 51-61. [CrossRef]

68. Denery, J.R.; Dragull, K.; Tang, C.; Li, Q.X. Pressurized fluid extraction of carotenoids from Haematococcus pluvialis and Dunaliella salina and kavalactones from Piper methysticum. Anal. Chim. Acta 2004, 501, 175-181. [CrossRef]

69. Haque, F.; Dutta, A.; Thimmanagari, M.; Chiang, Y.W. Intensified green production of astaxanthin from Haematococcus pluvialis. Food Bioprod. Process. 2016, 99, 1-11. [CrossRef]

70. Olaizola, M. Commercial production of astaxanthin from Haematococcus pluvialis using 25,000-liter outdoor photobioreactors. J. Appl. Phycol. 2000, 12, 499-506. [CrossRef]

71. Dufossé, L.; Galaup, P.; Yaron, A.; Arad, S.M.; Blanc, P.; Murthy, K.N.C.; Ravishankar, G.A. Microorganisms and microalgae as sources of pigments for food use: A scientific oddity or an industrial reality? Trends Food Sci. Tech. 2005, 16, 389-406. [CrossRef]

72. Mendes, A.; Reis, A.; Vasconcelos, R.; Guerra, P.; da Silva, T.L. Crypthecodinium cohnii with emphasis on DHA production: A review. J. Appl. Phycol. 2009, 21, 199-214. [CrossRef]

73. Kagan, M.L.; Levy, A.; Leikin-Frenkel, A. Comparative study of tissue deposition of omega-3 fatty acids from polar-lipid rich oil of the microalgae Nannochloropsis oculata with krill oil in rats. Food Funct. 2015, 6, 185-191. [CrossRef] [PubMed]

74. Kagan, M.L.; West, A.L.; Zante, C.; Calder, P.C. Acute appearance of fatty acids in human plasma-a comparative study between polar-lipid rich oil from the microalgae Nannochloropsis oculata and krill oil in healthy young males. Lipids Health Dis. 2013, 12, 102. [CrossRef] [PubMed]

75. Li, S.; Ji, L.; Shi, Q.; Wu, H.; Fan, J. Advances in the production of bioactive substances from marine unicellular microalgae Porphyridium spp. Bioresour. Technol. 2019, 292, 122048. [CrossRef] [PubMed]

76. Marcati, A.; Ursu, A.V.; Laroche, C.; Soanen, N.; Marchal, L.; Jubeau, S.; Djelveh, G.; Michaud, P. Extraction and fractionation of polysaccharides and B-phycoerythrin from the microalga Porphyridium cruentum by membrane technology. Algal Res. 2014, 5, 258-263. [CrossRef]

77. Sathasivam, R.; Radhakrishnan, R.; Hashem, A.; Abd_Allah, E.F. Microalgae metabolites: A rich source for food and medicine. Saudi J. Biol. Sci. 2019, 26, 709-722. [CrossRef]

78. Ahuja, K.; Singh, S. Algae Protein Market. Size by Source; Global Market Insights, Inc.: Selbyville, DE, USA, 2020.

79. Capelli, B.; Cysewski, G.R. Potential health benefits of spirulina microalgae. Nutrafoods 2010, 9, 19-26. [CrossRef]

80. CHITOSE Group. Tavelmout; A Japanese Algae-Based Protein Start-Up; Raised Total 1.7 Billion Japanese Yen. Preparing for World Wide Increasing Protein Demand. Available online: https:/ / chitose-bio.com/news/792/ (accessed on 10 September 2020).

81. Siva Kiran, R.; Madhu, G.; Satyanarayana, S. Spirulina in combating protein energy malnutrition (PEM) and protein energy wasting (PEW)-A review. J. Nutr. Res. 2015, 3, 62-79.

82. Ak, B.; Avsaroglu, E.; Isik, O.; Özyurt, G.; Kafkas, E.; Etyemez, M. Nutritional and physicochemical characteristics of bread enriched with microalgae Spirulina platensis. Int. J. Eng. Res. Appl. 2016, 6, 30-38.

83. Niccolai, A.; Venturi, M.; Galli, V.; Pini, N.; Rodolfi, L.; Biondi, N.; D’Ottavio, M.; Batista, A.P.; Raymundo, A.; Granchi, L. Development of new microalgae-based sourdough "crostini": Functional effects of Arthrospira platensis (spirulina) addition. Sci. Rep. 2019, 9, 1-12. [CrossRef] [PubMed]

84. Grahl, S.; Strack, M.; Weinrich, R.; Mörlein, D. Consumer-oriented product development: The conceptualization of novel food products based on spirulina (arthrospira platensis) and resulting consumer expectations. J. Food Qual. 2018, 2018. [CrossRef]

85. Stanic-Vucinic, D.; Minic, S.; Nikolic, M.R.; Velickovic, T.C. Spirulina phycobiliproteins as food components and complements. In Microalgal Biotechnology; IntechOpen: London, UK, 2018.

86. Chiong, T.; Acquah, C.; Lau, S.; Khor, E.; Danquah, M. Microalgal-based protein by-products: Extraction, purification, and applications. In Protein Byproducts; Elsevier/Academic Press: London, UK, 2016; pp. 213-234.

87. Ursu, A.-V.; Marcati, A.; Sayd, T.; Sante-Lhoutellier, V.; Djelveh, G.; Michaud, P. Extraction, fractionation and functional properties of proteins from the microalgae Chlorella vulgaris. Bioresour. Technol. 2014, 157, 134-139. [CrossRef] [PubMed]

88. Chia, S.R.; Chew, K.W.; Mohd Zaid, H.F.; Chu, D.-T.; Tao, Y.; Show, P.L. Microalgal protein extraction from Chlorella vulgaris FSP-E using triphasic partitioning technique with sonication. Front. Bioeng. Biotechnol. 2019, 7, 396. [CrossRef] [PubMed]

89. FAO/WHO. Energy and Protein Requirement; Report of a Joint FAO/WHO ad hoc Expert Committee; World Health Organization (WHO): Geneva, Switzerland, 1973.

90. Becker, E.W. Micro-algae as a source of protein. Biotechnol. Adv. 2007, 25, 207-210. [CrossRef]

91. Kent, M.; Welladsen, H.M.; Mangott, A.; Li, Y. Nutritional evaluation of Australian microalgae as potential human health supplements. PLoS ONE 2015, 10, e0118985. [CrossRef]

92. Seghiri, R.; Kharbach, M.; Essamri, A. Functional composition, nutritional properties, and biological activities of Moroccan Spirulina microalga. J. Food Qual. 2019, 2019. [CrossRef] 
93. Tibbetts, S.M.; Milley, J.E.; Lall, S.P. Chemical composition and nutritional properties of freshwater and marine microalgal biomass cultured in photobioreactors. J. Appl. Phycol. 2015, 27, 1109-1119. [CrossRef]

94. Annapurna, V.; Deosthale, Y.; Bamji, M.S. Spirulina as a source of vitamin A. Plant Foods Hum. Nutr. 1991, 41, 125-134. [CrossRef]

95. Annapurna, V.; Shah, N.; Bhaskaram, P.; Bamji, M.S.; Reddy, V. Bioavailability of spirulina carotenes in preschool children. J. Clin. Biochem. Nutr. 1991, 10, 145-151. [CrossRef]

96. Watanabe, F.; Katsura, H.; Takenaka, S.; Fujita, T.; Abe, K.; Tamura, Y.; Nakatsuka, T.; Nakano, Y. Pseudovitamin B12 is the predominant cobamide of an algal health food, spirulina tablets. J. Agric. Food Chem. 1999, 47, 4736-4741. [CrossRef] [PubMed]

97. Madhubalaji, C.K.; Rashmi, V.; Chauhan, V.S.; Shylaja, M.D.; Sarada, R. Improvement of vitamin B12 status with Spirulina supplementation in Wistar rats validated through functional and circulatory markers. J. Food Biochem. 2019, 43, e13038. [CrossRef]

98. Puyfoulhoux, G.; Rouanet, J.-M.; Besançon, P.; Baroux, B.; Baccou, J.-C.; Caporiccio, B. Iron availability from iron-fortified spirulina by an in vitro digestion/Caco-2 cell culture model. J. Agric. Food Chem. 2001, 49, 1625-1629. [CrossRef] [PubMed]

99. Silva, J.; Alves, C.; Pinteus, S.; Reboleira, J.; Pedrosa, R.; Bernardino, S. Chapter 3.10—Chlorella. In Nonvitamin and Nonmineral Nutritional Supplements; Nabavi, S.M., Silva, A.S., Eds.; Elsevier/Academic Press: London, UK, 2019; pp. 187-193. [CrossRef]

100. Merchant, R.E.; Phillips, T.W.; Udani, J. Nutritional supplementation with Chlorella pyrenoidosa lowers serum methylmalonic acid in vegans and vegetarians with a suspected vitamin B12 deficiency. J. Med. Food 2015, 18, 1357-1362. [CrossRef] [PubMed]

101. Nakano, S.; Takekoshi, H.; Nakano, M. Chlorella pyrenoidosa supplementation reduces the risk of anemia, proteinuria and edema in pregnant women. Plant Foods Hum. Nutr. 2010, 65, 25-30. [CrossRef] [PubMed]

102. Chronopoulou, L.; Dal Bosco, C.; di Caprio, F.; Prosini, L.; Gentili, A.; Pagnanelli, F.; Palocci, C. Extraction of carotenoids and fat-soluble vitamins from Tetradesmus Obliquus microalgae: An optimized approach by using supercritical $\mathrm{CO}_{2} . \mathrm{Molecules}^{2019}$, 24, 2581. [CrossRef]

103. Kumudha, A.; Sarada, R. Effect of different extraction methods on vitamin $\mathrm{B}_{12}$ from blue green algae, Spirulina platensis. Pharm. Anal. Acta 2015, 6. [CrossRef]

104. Tomdio, A.; Ritchie, M.; Miller, A.C. Omega-3 fatty acids and cardiovascular disease prevention. Am. Fam. Physician 2019, 100, 209-210.

105. Shahidi, F. Omega-3 oils: Sources, applications, and health effects. In Marine Nutraceuticals and Functional Foods; Shahidi, F., Barrow, C., Eds.; CRC Press/Taylor and Francis Group: Boca Raton, FL, USA, 2008; pp. $23-61$.

106. Sivaramakrishnan, R.; Incharoensakdi, A. Enhancement of total lipid yield by nitrogen, carbon, and iron supplementation in isolated microalgae. J. Phycol. 2017, 53, 855-868. [CrossRef]

107. Goncalves, E.C.; Wilkie, A.C.; Kirst, M.; Rathinasabapathi, B. Metabolic regulation of triacylglycerol accumulation in the green algae: Identification of potential targets for engineering to improve oil yield. Plant Biotechnol. J. 2016, 14, 1649-1660. [CrossRef]

108. Wang, X.; Fosse, H.K.; Li, K.; Chauton, M.S.; Vadstein, O.; Reitan, K.I. Influence of nitrogen limitation on lipid accumulation and EPA and DHA content in four marine microalgae for possible use in aquafeed. Front. Mar. Sci. 2019, 6, 95. [CrossRef]

109. Hoffmann, M.; Marxen, K.; Schulz, R.; Vanselow, K.H. TFA and EPA productivities of Nannochloropsis salina influenced by temperature and nitrate stimuli in turbidostatic controlled experiments. Mar. Drugs 2010, 8, 2526-2545. [CrossRef] [PubMed]

110. Van Wagenen, J.; Miller, T.W.; Hobbs, S.; Hook, P.; Crowe, B.; Huesemann, M. Effects of light and temperature on fatty acid production in Nannochloropsis salina. Energies 2012, 5, 731-740. [CrossRef]

111. Sato, N.; Tsuzuki, M.; Kawaguchi, A. Glycerolipid synthesis in Chlorella kessleri 11 h: II. Effect of the $\mathrm{CO}_{2}$ concentration during growth. Biochim. Biophys. Acta Mol. Cell Biol. Lipids 2003, 1633, 35-42. [CrossRef]

112. Tatsuzawa, H.; Takizawa, E.; Wada, M.; Yamamoto, Y. Fatty acid and lipid composition of the acidophilic green alga Chlamydomonas sp. 1. J. Phycol. 1996, 32, 598-601. [CrossRef]

113. Kapoore, R.V.; Butler, T.O.; Pandhal, J.; Vaidyanathan, S. Microwave-assisted extraction for microalgae: From biofuels to biorefinery. Biology 2018, 7, 18. [CrossRef]

114. Lorente, E.; Hapońska, M.; Clavero, E.; Torras, C.; Salvadó, J. Steam explosion and vibrating membrane filtration to improve the processing cost of microalgae cell disruption and fractionation. Processes 2018, 6, 28. [CrossRef]

115. Cuellar-Bermudez, S.P.; Aguilar-Hernandez, I.; Cardenas-Chavez, D.L.; Ornelas-Soto, N.; Romero-Ogawa, M.A.; Parra-Saldivar, R. Extraction and purification of high-value metabolites from microalgae: Essential lipids, astaxanthin and phycobiliproteins. Microb. Biotechnol. 2015, 8, 190-209. [CrossRef]

116. Martins, D.A.; Custódio, L.; Barreira, L.; Pereira, H.; Ben-Hamadou, R.; Varela, J.; Abu-Salah, K.M. Alternative sources of n-3 long-chain polyunsaturated fatty acids in marine microalgae. Mar. Drugs 2013, 11, 2259-2281. [CrossRef]

117. Coward, T.; Fuentes-Grünewald, C.; Silkina, A.; Oatley-Radcliffe, D.L.; Llewellyn, G.; Lovitt, R.W. Utilising light-emitting diodes of specific narrow wavelengths for the optimization and co-production of multiple high-value compounds in Porphyridium purpureum. Bioresour. Technol. 2016, 221, 607-615. [CrossRef]

118. Gao, B.; Chen, A.; Zhang, W.; Li, A.; Zhang, C. Co-production of lipids, eicosapentaenoic acid, fucoxanthin, and chrysolaminarin by Phaeodactylum tricornutum cultured in a flat-plate photobioreactor under varying nitrogen conditions. J. Ocean Univ. China 2017, 16, 916-924. [CrossRef]

119. Okafor, S.N.; Obonga, W.; Ezeokonkwo, M.A.; Nurudeen, J.; Orovwigho, U.; Ahiabuike, J. Assessment of the health implications of synthetic and natural food colourants-A critical review. UK J. Pharm. Biosci. 2016, 4, 1-11. [CrossRef] 
120. Schultz, H. NutraIngredients USA: Chinese Suppliers Angling to Snare Bigger Share of Natural Astaxanthin Market. Available online: https:/ / www.nutraingredients-usa.com/Article/2015/04/13/Chinese-suppliers-angling-to-snare-bigger-shareof-natural-astaxanthin-market (accessed on 5 September 2020).

121. Chacón-Lee, T.; González-Mariño, G. Microalgae for "Healthy" Foods-Possibilities and Challenges. Compr. Rev. Food Sci. Food Saf. 2010, 9, 655-675. [CrossRef]

122. Ambati, R.R.; Phang, S.-M.; Ravi, S.; Aswathanarayana, R.G. Astaxanthin: Sources, extraction, stability, biological activities and its commercial applications-A review. Mar. Drugs 2014, 12, 128-152. [CrossRef] [PubMed]

123. Evans, D.A.; Rabie, M. Algal and Algal Extract Dietary Supplement Composition. U.S. Patent Application WO 2007/062274 A1, 31 May 2007.

124. Silva, S.C.; Ferreira, I.C.; Dias, M.M.; Barreiro, M.F. Microalgae-derived pigments: A 10-year bibliometric review and industry and market trend analysis. Molecules 2020, 25, 3406. [CrossRef] [PubMed]

125. Dasgupta, C.N. Algae as a source of phycocyanin and other industrially important pigments. In Algal Biorefinery: An Integrated Approach; Springer International Publishing and Capital Publishing Company: New Delhi, India, 2015; pp. $253-276$.

126. Chen, C.-Y.; Kao, P.-C.; Tan, C.H.; Show, P.L.; Cheah, W.Y.; Lee, W.-L.; Ling, T.C.; Chang, J.-S. Using an innovative pH-stat CO 2 feeding strategy to enhance cell growth and C-phycocyanin production from Spirulina platensis. Biochem. Eng. J. 2016, 112, 78-85. [CrossRef]

127. Bryant, D.A.; Guglielmi, G.; de Marsac, N.T.; Castets, A.-M.; Cohen-Bazire, G. The structure of cyanobacterial phycobilisomes: A model. Arch. Microbiol. 1979, 123, 113-127. [CrossRef]

128. Galetović, A.; Seura, F.; Gallardo, V.; Graves, R.; Cortés, J.; Valdivia, C.; Núñez, J.; Tapia, C.; Neira, I.; Sanzana, S. Use of phycobiliproteins from atacama cyanobacteria as food colorants in a dairy beverage prototype. Foods 2020, 9, 244. [CrossRef]

129. USFDA. Summary of Color Additives for Use in the United States in Foods, Drugs, Cosmetics, and Medical Devices. Available online: https: / / www.fda.gov/industry/color-additive-inventories/summary-color-additives-use-united-states-foods-drugscosmetics-and-medical-devices (accessed on 17 September 2020).

130. Hejazi, M.A.; Wijffels, R.H. Milking of microalgae. Trends Biotechnol. 2004, 22, 189-194. [CrossRef]

131. Zhu, Y.-H.; Jiang, J.-G. Continuous cultivation of Dunaliella salina in photobioreactor for the production of $\beta$-carotene. Eur. Food Res. Technol. 2008, 227, 953-959. [CrossRef]

132. Pourkarimi, S.; Hallajisani, A.; Alizadehdakhel, A.; Golzary, A. Factors affecting production of beta-carotene from Dunaliella salina microalgae. Biocatal. Agric. Biotechnol. 2020, 101771. [CrossRef]

133. Xu, Y.; Harvey, P.J. Carotenoid production by Dunaliella salina under red light. Antioxidants 2019, 8, 123. [CrossRef] [PubMed]

134. Ruane, M. Extraction of Caroteniferous Materials from Algae. Australian Patent No. 7,239,574, 1977.

135. Pirwitz, K.; Flassig, R.J.; Rihko-Struckmann, L.K.; Sundmacher, K. Energy and operating cost assessment of competing harvesting methods for D. salina in a $\beta$-carotene production process. Algal Res. 2015, 12, 161-169. [CrossRef]

136. Singh, D.P.; Khattar, J.S.; Rajput, A.; Chaudhary, R.; Singh, R. High production of carotenoids by the green microalga Asterarcys quadricellulare PUMCC 5.1. 1 under optimized culture conditions. PLoS ONE 2019, 14, e0221930. [CrossRef] [PubMed]

137. Kaushal, S.; Singh, Y.; Khattar, J.; Singh, D. Phycobiliprotein production by a novel cold desert cyanobacterium Nodularia sphaerocarpa PUPCCC 420.1. J. Appl. Phycol. 2017, 29, 1819-1827. [CrossRef]

138. Katiyar, S.; Elmets, C.A.; Katiyar, S.K. Green tea and skin cancer: Photoimmunology, angiogenesis and DNA repair. J. Nutr. Biochem. 2007, 18, 287-296. [CrossRef]

139. Pérez-Sánchez, A.; Barrajón-Catalán, E.; Herranz-López, M.; Micol, V. Nutraceuticals for skin care: A comprehensive review of human clinical studies. Nutrients 2018, 10, 403. [CrossRef]

140. Pangestuti, R.; Suryaningtyas, I.T.; Siahaan, E.A.; Kim, S.-K. Cosmetics and cosmeceutical applications of microalgae pigments. In Pigments from Microalgae Handbook; Springer Nature: Cham, Switzerland, 2020; pp. 611-633.

141. Sawant, S.S.; Mane, V.K. Correlating the anti-aging activity with the bioactive profile of Chlorella emersonii KJ725233; its Toxicological Studies for a Potential use in Cosmeceuticals. Pharmacogn. Commun. 2017, 7, 152-157. [CrossRef]

142. Mourelle, M.L.; Gómez, C.P.; Legido, J.L. The potential use of marine microalgae and cyanobacteria in cosmetics and thalassotherapy. Cosmetics 2017, 4, 46. [CrossRef]

143. Stramarkou, M.; Papadaki, S.; Kyriakopoulou, K.; Krokida, M. Recovery of functional pigments from four different species of microalgae. IOSR J. Environ. Sci. Toxicol. Food Technol. 2016, 10, 26-30. [CrossRef]

144. Bilal, M.; Rasheed, T.; Ahmed, I.; Iqbal, H.M. High-value compounds from microalgae with industrial exploitability-A review. Front. Biosci. 2017, 9, 319-342.

145. De Jesus Raposo, M.F.; de Morais, R.M.S.C.; de Morais, A.M.M.B. Health applications of bioactive compounds from marine microalgae. Life Sci. 2013, 93, 479-486. [CrossRef] [PubMed]

146. Sathasivam, R.; Ki, J.-S. A review of the biological activities of microalgal carotenoids and their potential use in healthcare and cosmetic industries. Mar. Drugs 2018, 16, 26. [CrossRef] [PubMed]

147. Mäki-Arvela, P.; Hachemi, I.; Murzin, D.Y. Comparative study of the extraction methods for recovery of carotenoids from algae: Extraction kinetics and effect of different extraction parameters. J. Chem. Technol. Biotechnol. 2014, 89, 1607-1626. [CrossRef]

148. Bhalamurugan, G.L.; Valerie, O.; Mark, L.; Bhalamurugan, G.L.; Valerie, O.; Mark, L. Valuable bioproducts obtained from microalgal biomass and their commercial applications: A review. Environ. Eng. Res. 2018, 23, 229-241. [CrossRef] 
149. Lephart, E.D. Skin aging and oxidative stress: Equol's anti-aging effects via biochemical and molecular mechanisms. Ageing Res. Rev. 2016, 31, 36-54. [CrossRef]

150. Davinelli, S.; Nielsen, M.E.; Scapagnini, G. Astaxanthin in skin health, repair, and disease: A comprehensive review. Nutrients 2018, 10, 522. [CrossRef]

151. Ryu, B.; Himaya, S.; Kim, S.-K. Applications of microalgae-derived active ingredients as cosmeceuticals. In Handbook of Marine Microalgae; Elsevier/Academic Press: London, UK, 2015; pp. 309-316.

152. Kim, H.M.; Jung, J.H.; Kim, J.Y.; Heo, J.; Cho, D.H.; Kim, H.S.; An, S.; An, I.S.; Bae, S. The protective effect of violaxanthin from Nannochloropsis oceanica against ultraviolet B-induced damage in normal human dermal fibroblasts. Photochem. Photobiol. 2019, 95, 595-604. [CrossRef]

153. Matsui, M.; Tanaka, K.; Higashiguchi, N.; Okawa, H.; Yamada, Y.; Tanaka, K.; Taira, S.; Aoyama, T.; Takanishi, M.; Natsume, C. Protective and therapeutic effects of fucoxanthin against sunburn caused by UV irradiation. J. Pharmacol. Sci. 2016, $132,55-64$. [CrossRef]

154. Begum, H.; Yusoff, F.M.; Banerjee, S.; Khatoon, H.; Shariff, M. Availability and utilisation of pigments from microalgae. Crit. Rev. Food Sci. Nutr. 2016, 56, 2209-2222. [CrossRef]

155. Chakdar, H.; Pabbi, S. Algal pigments for human health and cosmeceuticals. In Algal Green Chemistry; Elsevier: Amsterdam, The Netherlands, 2017; pp. 171-188.

156. Biba, E. Protection: The sunscreen pill. Nature 2014, 515, S124-S125. [CrossRef] [PubMed]

157. Godin, B.; Touitou, E. Transdermal skin delivery: Predictions for humans from in vivo, ex vivo and animal models. Adv. Drug Deliv. Rev. 2007, 59, 1152-1161. [CrossRef] [PubMed]

158. Shen, C.-T.; Chen, P.-Y.; Wu, J.-J.; Lee, T.-M.; Hsu, S.-L.; Chang, C.-M.J.; Young, C.-C.; Shieh, C.-J. Purification of algal antityrosinase zeaxanthin from Nannochloropsis oculata using supercritical anti-solvent precipitation. J. Supercrit. Fluids 2011, 55, 955-962. [CrossRef]

159. Rao, A.R.; Sindhuja, H.; Dharmesh, S.M.; Sankar, K.U.; Sarada, R.; Ravishankar, G.A. Effective inhibition of skin cancer, tyrosinase, and antioxidative properties by astaxanthin and astaxanthin esters from the green alga Haematococcus pluvialis. J. Agric. Food Chem. 2013, 61, 3842-3851. [CrossRef]

160. Bonté, F. Skin moisturization mechanisms: New data. Ann. Pharm. Fr. 2011, 69, 135-141. [CrossRef]

161. Wang, H.-M.D.; Chen, C.-C.; Huynh, P.; Chang, J.-S. Exploring the potential of using algae in cosmetics. Bioresour. Technol. 2015, 184, 355-362. [CrossRef]

162. Zanella, L.; Alam, M.A. Extracts and bioactives from microalgae (sensu stricto): Opportunities and challenges for a new generation of cosmetics. In Microalgae Biotechnology for Food, Health and High Value Products; Springer Nature: Singapore, 2020; pp. 295-349.

163. Zmijewski, M.A.; Slominski, A.T. Neuroendocrinology of the skin: An overview and selective analysis. Dermatoendocrinology 2011, 3, 3-10. [CrossRef]

164. Alexopoulos, A.; Chrousos, G.P. Stress-related skin disorders. Rev. Endocr. Metab. Disord. 2016, 17, 295-304. [CrossRef]

165. Truzzi, F.; Marconi, A.; Pincelli, C. Neurotrophins in healthy and diseased skin. Dermatoendocrinology 2011, 3, 32-36. [CrossRef]

166. Borroni, R.; Truzzi, F.; Pincelli, C. The skin neurotrophic network in health and disease. Actas Dermo-Sifiliogr. 2009, 100, 70-74. [CrossRef]

167. Grewe, M.; Vogelsang, K.; Ruzicka, T.; Stege, H.; Krutmann, J. Neurotrophin-4 production by human epidermal keratinocytes: Increased expression in atopic dermatitis. J. Investig. Dermatol. 2000, 114, 1108-1112. [CrossRef] [PubMed]

168. Pavlovic, S.; Daniltchenko, M.; Tobin, D.J.; Hagen, E.; Hunt, S.P.; Klapp, B.F.; Arck, P.C.; Peters, E.M. Further exploring the brain-skin connection: Stress worsens dermatitis via substance P-dependent neurogenic inflammation in mice. J. Investig. Dermatol. 2008, 128, 434-446. [CrossRef] [PubMed]

169. Kinkelin, I.; Bröcker, E.-B.; Koltzenburg, M.; Carlton, S.M. Localization of ionotropic glutamate receptors in peripheral axons of human skin. Neurosci. Lett. 2000, 283, 149-152. [CrossRef]

170. Sharma, K.; Sharma, D.; Sharma, M.; Sharma, N.; Bidve, P.; Prajapati, N.; Kalia, K.; Tiwari, V. Astaxanthin ameliorates behavioral and biochemical alterations in in-vitro and in-vivo model of neuropathic pain. Neurosci. Lett. 2018, 674, 162-170. [CrossRef] [PubMed]

171. Koller, M.; Muhr, A.; Braunegg, G. Microalgae as versatile cellular factories for valued products. Algal Res. 2014, 6, 52-63. [CrossRef]

172. Tredici, M.R.; Rodolfi, L.; Biondi, N.; Bassi, N.; Sampietro, G. Techno-economic analysis of microalgal biomass production in a 1-ha Green Wall Panel (GWP $\left.{ }^{\circledR}\right)$ plant. Algal Res. 2016, 19, 253-263. [CrossRef]

173. Fernandez, F.G.A.; Sevilla, J.M.F.; Grima, E.M. Microalgae: The basis of mankind sustainability. In Case Study of Innovative Projects-Successful Real Cases; Llamas, B., Ed.; Intech Open: London, UK, 2017; pp. 123-140.

174. Algae World News. Josie Maran Argan Beta Retinoid Pink Algae Serum is Unlike Anything Else. Available online: https://news. algaeworld.org/2020/01/josie-maran-argan-beta-retinoid-pink-algae-serum-is-unlike-anything-else/\#more-41347 (accessed on 18 September 2020).

175. Borowitzka, M.A. Microalgae as sources of pharmaceuticals and other biologically active compounds. J. Appl. Phycol. 1995, 7, 3-15. [CrossRef]

176. Morvan, P.; Vallee, R. Effects of Chlorella Extract on Skin-Personal Care Magazine. Available online: https://www.kako-shujsati. com/hujsanje-trebuh/images/chlorella-extract-on-skin.pdf (accessed on 19 September 2020). 
177. Guillerme, J.-B.; Couteau, C.; Coiffard, L. Applications for marine resources in cosmetics. Cosmetics 2017, 4, 35. [CrossRef]

178. Maiz, D. The underwater world: A source of inexhaustible inspiration. Parf. Cosmet. Actual 2007, 194, 136-160.

179. Campiche, R.; Sandau, P.; Kurth, E.; Massironi, M.; Imfeld, D.; Schuetz, R. Protective effects of an extract of the freshwater microalga Scenedesmus rubescens on UV-irradiated skin cells. Int. J. Cosmet. Sci. 2018, 40, 187-192. [CrossRef]

180. Stolz, P.; Obermayer, B. Manufacturing microalgae for skin care. Cosmet. Toilet. 2005, 120, 99-106.

181. Joshi, S.; Kumari, R.; Upasani, V.N. Applications of algae in cosmetics: An overview. Int. J. Innov. Res. Sci. Eng. Technol. 2018, 7,1269 .

182. Hussian, A. The role of microalgae in renewable energy production: Challenges and opportunities. In Marine Ecology-Biotic and Abiotic Interactions; Türkoğlu, M., Önal, U., Ismen, A., Eds.; Intech Open: London, UK, 2018; pp. 257-283. [CrossRef]

183. Musa, M.; Ayoko, G.A.; Ward, A.; Rösch, C.; Brown, R.J.; Rainey, T.J. Factors affecting microalgae production for biofuels and the potentials of chemometric methods in assessing and optimizing productivity. Cells 2019, 8, 851. [CrossRef] [PubMed]

184. Bayro-Kaiser, V.; Nelson, N. Microalgal hydrogen production: Prospects of an essential technology for a clean and sustainable energy economy. Photosynth. Res. 2017, 133, 49-62. [CrossRef] [PubMed]

185. Ganesan, R.; Manigandan, S.; Samuel, M.S.; Shanmuganathan, R.; Brindhadevi, K.; Chi, N.T.L.; Duc, P.A.; Pugazhendhi, A. A review on prospective production of biofuel from microalgae. Biotechnol. Rep. 2020, 27, e00509. [CrossRef]

186. Hamed, I. The evolution and versatility of microalgal biotechnology: A review. Compr. Rev. Food Sci. Food Saf. 2016, 15, 1104-1123. [CrossRef]

187. Cruz, Y.R.; Aranda, D.A.; Seidl, P.R.; Diaz, G.C.; Carliz, R.G.; Fortes, M.M.; da Ponte, D.; de Paula, R.C. Cultivation systems of microalgae for the production of biofuels. In Biofuels-State of Development; Biernat, K., Ed.; Intech Open: London, UK, 2018; pp. $199-218$.

188. Abo, B.O.; Odey, E.A.; Bakayoko, M.; Kalakodio, L. Microalgae to biofuels production: A review on cultivation, application and renewable energy. Rev. Environ. Health 2019, 34, 91-99. [CrossRef]

189. USDOE. Biomass Conversion: From Feedstocks to Final Products. Available online: https://www.energy.gov/sites/prod/files/ 2016/07/f33/conversion_factsheet.pdf (accessed on 1 October 2020).

190. Nasreen, S.; Nafees, M.; Qureshi, L.A.; Asad, M.S.; Sadiq, A.; Ali, S.D. Review of catalytic transesterification methods for biodiesel production. In Biofuels: State of Development; Biernat, K., Ed.; Intech Open: London, UK, 2018; pp. 93-119.

191. Taher, H.; Al-Zuhair, S.; Al-Marzouqi, A.H.; Haik, Y.; Farid, M.M. A review of enzymatic transesterification of microalgal oil-based biodiesel using supercritical technology. Enzyme Res. 2011, 2011. [CrossRef]

192. Gouveia, L.; Oliveira, A.C. Microalgae as a raw material for biofuels production. J. Ind. Microbiol. Biotechnol. 2009, 36, 269-274. [CrossRef]

193. Dasan, Y.K.; Lam, M.K.; Yusup, S.; Lim, J.W.; Lee, K.T. Life cycle evaluation of microalgae biofuels production: Effect of cultivation system on energy, carbon emission and cost balance analysis. Sci. Total Environ. 2019, 688, 112-128. [CrossRef]

194. Sheehan, J.; Camobreco, V.; Duffield, J.; Graboski, M.; Shapouri, H. An Overview of Biodiesel and Petroleum Diesel Life Cycles; National Renewable Energy Lab. (NREL): Golden, CO, USA; US Department of Energy (DOE): Oak Ridge, TN, USA, 1998.

195. Wang, H.; Ji, C.; Bi, S.; Zhou, P.; Chen, L.; Liu, T. Joint production of biodiesel and bioethanol from filamentous oleaginous microalgae Tribonema sp. Bioresour. Technol. 2014, 172, 169-173. [CrossRef] [PubMed]

196. Khan, M.I.; Shin, J.H.; Kim, J.D. The promising future of microalgae: Current status, challenges, and optimization of a sustainable and renewable industry for biofuels, feed, and other products. Microb. Cell Fact. 2018, 17, 36. [CrossRef] [PubMed]

197. Rempel, A.; Machado, T.; Treichel, H.; Colla, E.; Margarites, A.C.; Colla, L.M. Saccharification of Spirulina platensis biomass using free and immobilized amylolytic enzymes. Bioresour. Technol. 2018, 263, 163-171. [CrossRef] [PubMed]

198. De Farias Silva, C.E.; Bertucco, A. Bioethanol from microalgae and cyanobacteria: A review and technological outlook. Process Biochem. 2016, 51, 1833-1842. [CrossRef]

199. Astolfi, A.L.; Rempel, A.; Cavanhi, V.A.F.; Alves, M.; Deamici, K.M.; Colla, L.M.; Costa, J.A.V. Simultaneous saccharification and fermentation of Spirulina sp. and corn starch for the production of bioethanol and obtaining biopeptides with high antioxidant activity. Bioresour. Technol. 2020, 301, 122698. [CrossRef]

200. Patidar, J.; Sharma, R.; Yadav, M.; Tiwari, A. Microalgae as sustainable renewable energy feedstock for bioethanol production. Sch. Acad. J. Biosci. 2017, 5, 536-542. [CrossRef]

201. Kim, H.M.; Oh, C.H.; Bae, H.-J. Comparison of red microalgae (Porphyridium cruentum) culture conditions for bioethanol production. Bioresour. Technol. 2017, 233, 44-50. [CrossRef]

202. Chandra, N.; Shukla, P.; Mallick, N. Role of cultural variables in augmenting carbohydrate accumulation in the green microalga Scenedesmus acuminatus for bioethanol production. Biocatal. Agric. Biotechnol. 2020, 26, 101632. [CrossRef]

203. Harun, R.; Jason, W.; Cherrington, T.; Danquah, M.K. Exploring alkaline pre-treatment of microalgal biomass for bioethanol production. Appl. Energy 2011, 88, 3464-3467. [CrossRef]

204. Choi, S.P.; Nguyen, M.T.; Sim, S.J. Enzymatic pretreatment of Chlamydomonas reinhardtii biomass for ethanol production. Bioresour. Technol. 2010, 101, 5330-5336. [CrossRef]

205. Harun, R.; Danquah, M.K. Influence of acid pre-treatment on microalgal biomass for bioethanol production. Process Biochem. 2011, 46, 304-309. [CrossRef]

206. Guo, H.; Daroch, M.; Liu, L.; Qiu, G.; Geng, S.; Wang, G. Biochemical features and bioethanol production of microalgae from coastal waters of Pearl River Delta. Bioresour. Technol. 2013, 127, 422-428. [CrossRef] [PubMed] 
207. Ho, S.-H.; Huang, S.-W.; Chen, C.-Y.; Hasunuma, T.; Kondo, A.; Chang, J.-S. Bioethanol production using carbohydrate-rich microalgae biomass as feedstock. Bioresour. Technol. 2013, 135, 191-198. [CrossRef] [PubMed]

208. Ho, S.-H.; Li, P.-J.; Liu, C.-C.; Chang, J.-S. Bioprocess development on microalgae-based $\mathrm{CO}_{2}$ fixation and bioethanol production using Scenedesmus obliquus CNW-N. Bioresour. Technol. 2013, 145, 142-149. [CrossRef] [PubMed]

209. Rizza, L.S.; Smachetti, M.E.S.; Do Nascimento, M.; Salerno, G.L.; Curatti, L. Bioprospecting for native microalgae as an alternative source of sugars for the production of bioethanol. Algal Res. 2017, 22, 140-147. [CrossRef]

210. Wu, N.; Moreira, C.M.; Zhang, Y.; Doan, N.; Yang, S.; Phlips, E.J.; Svoronos, S.A.; Pullammanappallil, P.C. Techno-economic analysis of biogas production from microalgae through anaerobic digestion. In Anaerobic Digestion; IntechOpen: London, UK, 2019.

211. Milledge, J.J.; Nielsen, B.V.; Maneein, S.; Harvey, P.J. A brief review of anaerobic digestion of algae for bioenergy. Energies 2019, 12, 1166. [CrossRef]

212. Jankowska, E.; Sahu, A.K.; Oleskowicz-Popiel, P. Biogas from microalgae: Review on microalgae's cultivation, harvesting and pretreatment for anaerobic digestion. Renew. Sustain. Energy Rev. 2017, 75, 692-709. [CrossRef]

213. Wang, M.; Lee, E.; Dilbeck, M.P.; Liebelt, M.; Zhang, Q.; Ergas, S.J. Thermal pretreatment of microalgae for biomethane production: Experimental studies, kinetics and energy analysis. J. Chem. Technol. Biotechnol. 2017, 92, 399-407. [CrossRef]

214. Yu, J.; Takahashi, P. Biophotolysis-based hydrogen production by cyanobacteria and green microalgae. In Communicating Current Research and Educational Topics and Trends in Applied Microbiology; Méndez-Vilas, A., Ed.; FORMATEX: Badajoz, Spain, 2007; Volume 1, pp. 79-89.

215. Nagarajan, D.; Lee, D.-J.; Kondo, A.; Chang, J.-S. Recent insights into biohydrogen production by microalgae-From biophotolysis to dark fermentation. Bioresour. Technol. 2017, 227, 373-387. [CrossRef]

216. Khetkorn, W.; Rastogi, R.P.; Incharoensakdi, A.; Lindblad, P.; Madamwar, D.; Pandey, A.; Larroche, C. Microalgal hydrogen production-A review. Bioresour. Technol. 2017, 243, 1194-1206. [CrossRef] [PubMed]

217. Maneeruttanarungroj, C.; Lindblad, P.; Incharoensakdi, A. A newly isolated green alga, Tetraspora sp. CU2551, from Thailand with efficient hydrogen production. Int. J. Hydrogen Energy 2010, 35, 13193-13199. [CrossRef]

218. Eroglu, E.; Melis, A. Photobiological hydrogen production: Recent advances and state of the art. Bioresour. Technol. 2011, 102, 8403-8413. [CrossRef] [PubMed]

219. Hwang, J.-H.; Kim, H.-C.; Choi, J.-A.; Abou-Shanab, R.; Dempsey, B.A.; Regan, J.M.; Kim, J.R.; Song, H.; Nam, I.-H.; Kim, S.-N. Photoautotrophic hydrogen production by eukaryotic microalgae under aerobic conditions. Nat. Commun. 2014, 5, 1-6. [CrossRef] [PubMed]

220. Torzillo, G.; Scoma, A.; Faraloni, C.; Giannelli, L. Advances in the biotechnology of hydrogen production with the microalga Chlamydomonas reinhardtii. Crit. Rev. Biotechnol. 2015, 35, 485-496. [CrossRef]

221. Radakovits, R.; Jinkerson, R.E.; Darzins, A.; Posewitz, M.C. Genetic engineering of algae for enhanced biofuel production. Eukaryot Cell 2010, 9, 486-501. [CrossRef]

222. Chen, W.-H.; Lin, B.-J.; Huang, M.-Y.; Chang, J.-S. Thermochemical conversion of microalgal biomass into biofuels: A review. Bioresour. Technol. 2015, 184, 314-327. [CrossRef]

223. Adnan, M.A.; Hossain, M.M. CO2 gasification of microalgae (N. Oculata)-A thermodynamic study. MATEC Web Conf. 2018, 154, 01002. [CrossRef]

224. USDOE. Biofuel Basics. Available online: https:/ /www.energy.gov/eere/bioenergy/biofuels-basics (accessed on 1 October 2020).

225. Xu, Y.-P.; Duan, P.-G.; Wang, F.; Guan, Q.-Q. Liquid fuel generation from algal biomass via a two-step process: Effect of feedstocks. Biotechnol. Biofuels 2018, 11, 83. [CrossRef]

226. Wang, W.; Xu, Y.; Wang, X.; Zhang, B.; Tian, W.; Zhang, J. Hydrothermal liquefaction of microalgae over transition metal supported $\mathrm{TiO}_{2}$ catalyst. Bioresour. Technol. 2018, 250, 474-480. [CrossRef]

227. Adamczyk, M.; Sajdak, M. Pyrolysis behaviours of microalgae Nannochloropsis gaditana. Waste Biomass Valorization 2018, 9, $2221-2235$. [CrossRef]

228. International Energy Agency (IEA) Bioenergy. Task 34: Biomass Pyrolysis; Bioenergy Research Group, Aston University: Birmingham, UK, 2007; pp. 1-20.

229. Chye, J.T.T.; Jun, L.Y.; Yon, L.S.; Pan, S.; Danquah, M.K. Biofuel production from algal biomass. In Bioenergy and Biofuels, 1st ed.; Konur, O., Ed.; CRC Press/Taylor and Francis Group: Boca Raton, FL, USA, 2018; p. 621.

230. Quinn, J.C.; Davis, R. The potentials and challenges of algae based biofuels: A review of the techno-economic, life cycle, and resource assessment modeling. Bioresour. Technol. 2015, 184, 444-452. [CrossRef] [PubMed]

231. Leite, G.B.; Abdelaziz, A.E.; Hallenbeck, P.C. Algal biofuels: Challenges and opportunities. Bioresour. Technol. 2013, 145, $134-141$. [CrossRef] [PubMed]

232. Wen, Z. Algae for Biofuel Production. Available online: https://farm-energy.extension.org/algae-for-biofuel-production (accessed on 15 September 2020).

233. Biofuelwatch. Microalgae Biofuels Myths and Risks. Available online: https://haseloff.plantsci.cam.ac.uk/resources/SynBio_ reports/Microalgae-Biofuels-Myths-and-Risks-2017.pdf (accessed on 1 October 2020).

234. Ronga, D.; Biazzi, E.; Parati, K.; Carminati, D.; Carminati, E.; Tava, A. Microalgal biostimulants and biofertilisers in crop productions. Agronomy 2019, 9, 192. [CrossRef] 
235. Dineshkumar, R.; Rasheeq, A.A.; Arumugam, A.; Nambi, K.N.; Sampathkumar, P. Marine microalgal extracts on cultivable crops as a considerable bio-fertilizer: A Review. Indian J. Tradit. Knowl. 2019, 18, 849-854.

236. Pereira, I.; Ortega, R.; Barrientos, L.; Moya, M.; Reyes, G.; Kramm, V. Development of a biofertiliser based on filamentous nitrogen-fixing cyanobacteria for rice crops in Chile. J. Appl. Phycol. 2009, 21, 135-144. [CrossRef]

237. Osman, M.E.H.; El-Sheekh, M.M.; El-Naggar, A.H.; Gheda, S.F. Effect of two species of cyanobacteria as biofertilisers on some metabolic activities, growth, and yield of pea plant. Biol. Fertil. Soils 2010, 46, 861-875. [CrossRef]

238. Chittapun, S.; Limbipichai, S.; Amnuaysin, N.; Boonkerd, R.; Charoensook, M. Effects of using cyanobacteria and fertilizer on growth and yield of rice, Pathum Thani I: A pot experiment. J. Appl. Phycol. 2018, 30, 79-85. [CrossRef]

239. Agwa, O.; Ogugbue, C.; Williams, E. Field evidence of Chlorella vulgaris potentials as a biofertiliser for Hibiscus esculentus. Int. J. Agric. Res. 2017, 12, 181-189. [CrossRef]

240. Garcia-Gonzalez, J.; Sommerfeld, M. Biofertiliser and biostimulant properties of the microalga Acutodesmus dimorphus. J. Appl. Phycol. 2016, 28, 1051-1061. [CrossRef]

241. Dineshkumar, R.; Subramanian, J.; Gopalsamy, J.; Jayasingam, P.; Arumugam, A.; Kannadasan, S.; Sampathkumar, P. The impact of using microalgae as biofertiliser in maize (Zea mays L.). Waste Biomass Valorization 2019, 10, 1101-1110. [CrossRef]

242. Jochum, M.; Moncayo, L.P.; Jo, Y.-K. Microalgal cultivation for biofertilization in rice plants using a vertical semi-closed airlift photobioreactor. PLoS ONE 2018, 13, e0203456. [CrossRef] [PubMed]

243. Dineshkumar, R.; Subramanian, J.; Arumugam, A.; Rasheeq, A.A.; Sampathkumar, P. Exploring the microalgae biofertiliser effect on onion cultivation by field experiment. Waste Biomass Valorization 2020, 11, 77-87. [CrossRef]

244. Bumandalai, O.; Tserennadmid, R. Effect of Chlorella vulgaris as a biofertiliser on germination of tomato and cucumber seeds. Int. J. Aquat. Biol. 2019, 7, 95-99.

245. Nayak, M.; Swain, D.K.; Sen, R. Strategic valorization of de-oiled microalgal biomass waste as biofertiliser for sustainable and improved agriculture of rice (Oryza sativa L.) crop. Sci. Total Environ. 2019, 682, 475-484. [CrossRef] [PubMed]

246. Bocchi, S.; Malgioglio, A. Azolla-Anabaena as a biofertiliser for rice paddy fields in the Po Valley, a temperate rice area in Northern Italy. Int. J. Agron. 2010, 2010. [CrossRef]

247. Sholkamy, E.N.; El-Komy, H.; Al-Arfaj, A.A.; Abdel-Megeed, A.; Mostafa, A.A. Potential role of Nostoc muscorum and Nostoc rivulare as biofertilisers for the enhancement of maize growth under different doses of $\mathrm{n}$-fertilizer. Afr. J. Microbiol. Res. 2012, $6,7435-7448$.

248. Karthikeyan, N.; Prasanna, R.; Nain, L.; Kaushik, B.D. Evaluating the potential of plant growth promoting cyanobacteria as inoculants for wheat. Eur. J. Soil Biol. 2007, 43, 23-30. [CrossRef]

249. Uysal, O.; Uysal, F.O.; Ekinci, K. Evaluation of microalgae as microbial fertilizer. Eur. J. Sustain. Dev. 2015, 4, 77-82. [CrossRef]

250. Prasanna, R.; Kanchan, A.; Kaur, S.; Ramakrishnan, B.; Ranjan, K.; Singh, M.C.; Hasan, M.; Saxena, A.K.; Shivay, Y.S. Chrysanthemum growth gains from beneficial microbial interactions and fertility improvements in soil under protected cultivation. Hortic. Plant J. 2016, 2, 229-239. [CrossRef]

251. Prasanna, R.; Kanchan, A.; Ramakrishnan, B.; Ranjan, K.; Venkatachalam, S.; Hossain, F.; Shivay, Y.S.; Krishnan, P.; Nain, L. Cyanobacteria-based bioinoculants influence growth and yields by modulating the microbial communities favourably in the rhizospheres of maize hybrids. Eur. J. Soil Biol. 2016, 75, 15-23. [CrossRef]

252. Suleiman, A.K.A.; Lourenço, K.S.; Clark, C.; Luz, R.L.; da Silva, G.H.R.; Vet, L.E.M.; Cantarella, H.; Fernandes, T.V.; Kuramae, E.E. From toilet to agriculture: Fertilization with microalgal biomass from wastewater impacts the soil and rhizosphere active microbiomes, greenhouse gas emissions and plant growth. Resour. Conserv. Recycl. 2020, 161, 104924. [CrossRef]

253. Babu, S.; Prasanna, R.; Bidyarani, N.; Singh, R. Analysing the colonisation of inoculated cyanobacteria in wheat plants using biochemical and molecular tools. J. Appl. Phycol. 2015, 27, 327-338. [CrossRef]

254. Bidyarani, N.; Prasanna, R.; Chawla, G.; Babu, S.; Singh, R. Deciphering the factors associated with the colonization of rice plants by cyanobacteria. J. Basic Microbiol. 2015, 55, 407-419. [CrossRef] [PubMed]

255. Bidyarani, N.; Prasanna, R.; Babu, S.; Hossain, F.; Saxena, A.K. Enhancement of plant growth and yields in Chickpea (Cicer arietinum L.) through novel cyanobacterial and biofilmed inoculants. Microbiol. Res. 2016, 188, 97-105. [CrossRef]

256. Priya, H.; Prasanna, R.; Ramakrishnan, B.; Bidyarani, N.; Babu, S.; Thapa, S.; Renuka, N. Influence of cyanobacterial inoculation on the culturable microbiome and growth of rice. Microbiol. Res. 2015, 171, 78-89. [CrossRef]

257. Prasanna, R.; Ramakrishnan, B.; Simranjit, K.; Ranjan, K.; Kanchan, A.; Hossain, F.; Nain, L. Cyanobacterial and rhizobial inoculation modulates the plant physiological attributes and nodule microbial communities of chickpea. Arch. Microbiol. 2017, 199, 1311-1323. [CrossRef]

258. Ramakrishnan, B.; Kaur, S.; Prasanna, R.; Ranjan, K.; Kanchan, A.; Hossain, F.; Shivay, Y.S.; Nain, L. Microbial inoculation of seeds characteristically shapes the rhizosphere microbiome in desi and kabuli chickpea types. J. Soils Sediments 2017, 17, 2040-2053. [CrossRef]

259. Ahmed, E.; Holmström, S.J.M. Siderophores in environmental research: Roles and applications. Microb. Biotechnol. 2014, 7, 196-208. [CrossRef]

260. Årstøl, E.; Hohmann-Marriott, M.F. Cyanobacterial siderophores—Physiology, structure, biosynthesis, and applications. Mar. Drugs 2019, 17, 281. [CrossRef]

261. Mazur, H.; Konop, A.; Synak, R. Indole-3-acetic acid in the culture medium of two axenic green microalgae. J. Appl. Phycol. 2001, 13, 35-42. [CrossRef] 
262. Sergeeva, E.; Liaimer, A.; Bergman, B. Evidence for production of the phytohormone indole-3-acetic acid by cyanobacteria. Planta 2002, 215, 229-238. [CrossRef] [PubMed]

263. Romanenko, E.; Kosakovskaya, I.; Romanenko, P. Phytohormones of microalgae: Biological role and involvement in the regulation of physiological processes. Pt I. auxins, abscisic acid, ethylene. Int. J. Algae 2015, 17, 275-289. [CrossRef]

264. Stirk, W.; Ördög, V.; van Staden, J.; Jäger, K. Cytokinin-and auxin-like activity in Cyanophyta and microalgae. J. Appl. Phycol. 2002, 14, 215-221. [CrossRef]

265. Hussain, A.; Hasnain, S. Phytostimulation and biofertilization in wheat by cyanobacteria. J. Ind. Microbiol. Biotechnol. 2011, 38, 85-92. [CrossRef]

266. Kumar, M.; Prasanna, R.; Bidyarani, N.; Babu, S.; Mishra, B.K.; Kumar, A.; Adak, A.; Jauhari, S.; Yadav, K.; Singh, R. Evaluating the plant growth promoting ability of thermotolerant bacteria and cyanobacteria and their interactions with seed spice crops. Sci. Hortic. 2013, 164, 94-101. [CrossRef]

267. Grzesik, M.; Romanowska-Duda, Z.; Kalaji, H. Effectiveness of cyanobacteria and green algae in enhancing the photosynthetic performance and growth of willow (Salix viminalis L.) plants under limited synthetic fertilizers application. Photosynthetica 2017, 55, 510-521. [CrossRef]

268. Babu, S.; Bidyarani, N.; Chopra, P.; Monga, D.; Kumar, R.; Prasanna, R.; Kranthi, S.; Saxena, A.K. Evaluating microbe-plant interactions and varietal differences for enhancing biocontrol efficacy in root rot disease challenged cotton crop. Eur. J. Plant Pathol. 2015, 142, 345-362. [CrossRef]

269. Renuka, N.; Prasanna, R.; Sood, A.; Ahluwalia, A.S.; Bansal, R.; Babu, S.; Singh, R.; Shivay, Y.S.; Nain, L. Exploring the efficacy of wastewater-grown microalgal biomass as a biofertiliser for wheat. Environ. Sci. Pollut. Res. 2016, 23, 6608-6620. [CrossRef]

270. Renuka, N.; Prasanna, R.; Sood, A.; Bansal, R.; Bidyarani, N.; Singh, R.; Shivay, Y.S.; Nain, L.; Ahluwalia, A.S. Wastewater grown microalgal biomass as inoculants for improving micronutrient availability in wheat. Rhizosphere 2017, 3, 150-159. [CrossRef]

271. Chandini; Kumar, R.; Kumar, R.; Prakash, O. The impact of chemical fertilizers on our environment and ecosystem. In Research Trends in Environmental Sciences; Akinik Publications: New Delhi, India, 2019; pp. 69-86.

272. Mahapatra, D.M.; Chanakya, H.; Joshi, N.; Ramachandra, T.; Murthy, G. Algae-based biofertilisers: A biorefinery approach. In Microorganisms for Green Revolution; Springer Nature: Singapore, 2018; pp. 177-196.

273. Rojas Crespo, E.; Iglesias Hernandez, D.; Acien Fernandez, F.G.; Pozo Dengra, J. Method for Obtaining Concentrates of Biofertilisers and Biostimulants for Agricultural Use from Biomass of Microalgae, Including Cyanobacteria. U.S. Patent Application 6/575,483, 1 April 2020.

274. Ecological Pruducts Industries. Blue Green Algae Biofertiliser. Available online: https:/ / ecologicalproduct.tradeindia.com/bluegreen-algae-bio-fertilizer.html (accessed on 9 October 2020).

275. June Pharmaceutical Comp. Ltd. Spirulina Superfertilizers: Shwe Awzar ${ }^{\circledR}$. Available online: http://www.junespirulina.com/ products/Superfertilizes (accessed on 9 October 2020).

276. Biorizon Biotech. Spirulina: Algafert ${ }^{\circledR}$. Available online: http://www.biorizon.es/bio-booster/hydrolyzed/algafert/?lang=en (accessed on 9 October 2020).

277. MikroAlg Food Agric Ind Inc. Terradoc ${ }^{\circledR}$ Biofertiliser. Available online: http://mikroalg.com/urun-etiketi/terradoc-10 (accessed on 9 October 2020).

278. Accelergy Corp. TerraSyncTM Biofertiliser. Available online: http://algaebiomass.org/wp-content/gallery/2012-algae-biomasssummit/2010/06/Allen-Mark-Accelergy-Corporation-Carbon-Capture-and-Utilisation-Challenges-and-Opportunities.pdf (accessed on 9 October 2020).

279. MCT Tarim Ltd. Sti. Available online: https://mcttarim.en.ecplaza.net/products/emek-microbial-fertilizer_2956105 (accessed on 9 October 2020).

280. Emparan, Q.; Harun, R.; Danquah, M. Role of phycoremediation for nutrient removal from wastewaters: A review. Appl. Ecol. Environ. Res. 2019, 17, 889-915. [CrossRef]

281. Canizares, R.; Domínguez, A. Growth of Spirulina maxima on swine waste. Bioresour. Technol. 1993, 45, 73-75. [CrossRef]

282. Cañizares, R.; Rivas, L.; Montes, C.; Dominguez, A.; Travieso, L.; Benitez, F. Aerated swine-wastewater treatment with Kcarrageenan-immobilized Spirulina maxima. Bioresour. Technol. 1994, 47, 89-91. [CrossRef]

283. Lim, S.-L.; Chu, W.-L.; Phang, S.-M. Use of Chlorella vulgaris for bioremediation of textile wastewater. Bioresour. Technol. 2010, 101, 7314-7322. [CrossRef] [PubMed]

284. Chen, X.; Li, Z.; He, N.; Zheng, Y.; Li, H.; Wang, H.; Wang, Y.; Lu, Y.; Li, Q.; Peng, Y. Nitrogen and phosphorus removal from anaerobically digested wastewater by microalgae cultured in a novel membrane photobioreactor. Biotechnol. Biofuels 2018, 11, 190. [CrossRef] [PubMed]

285. Cañizares-Villanueva, R.; Martínez-Roldán, A.; Perales-Vela, H.; Vázquez-Hernández, M.; Melchy-Antonio, O. Bioremediation of Copper and Other Heavy Metals Using Microbial Biomass. In Handbook of Metal-Microbe Interactions and Bioremediation; Das, S., Dash, H.R., Eds.; CRC Press: Boca Raton, FL, USA, 2017; pp. 585-602. [CrossRef]

286. Dwivedi, S. Bioremediation of heavy metal by algae: Current and future perspective. J. Adv. Lab. Res. Biol. $2012,3,195-199$.

287. Hernández-Zamora, M.; Perales-Vela, H.V.; Flores-Ortíz, C.M.; Cañizares-Villanueva, R.O. Physiological and biochemical responses of Chlorella vulgaris to Congo Red. Ecotoxicol. Environ. Saf. 2014, 108, 72-77. [CrossRef]

288. Saratale, R.G.; Saratale, G.D.; Chang, J.-S.; Govindwar, S.P. Bacterial decolorization and degradation of azo dyes: A review. J. Taiwan Inst. Chem. Eng. 2011, 42, 138-157. [CrossRef] 
289. Bolong, N.; Ismail, A.; Salim, M.R.; Matsuura, T. A review of the effects of emerging contaminants in wastewater and options for their removal. Desalination 2009, 239, 229-246. [CrossRef]

290. Gavrilescu, M.; Demnerová, K.; Aamand, J.; Agathos, S.; Fava, F. Emerging pollutants in the environment: Present and future challenges in biomonitoring, ecological risks and bioremediation. New Biotechnol. 2015, 32, 147-156. [CrossRef]

291. Tolboom, S.N.; Carrillo-Nieves, D.; de Jesús Rostro-Alanis, M.; de la Cruz Quiroz, R.; Barceló, D.; Iqbal, H.M.; Parra-Saldivar, R. Algal-based removal strategies for hazardous contaminants from the environment-A review. Sci. Total Environ. 2019, 665, 358-366. [CrossRef]

292. Zhang, C.; Lu, J.; Wu, J.; Luo, Y. Phycoremediation of coastal waters contaminated with bisphenol A by green tidal algae Ulva prolifera. Sci. Total Environ. 2019, 661, 55-62. [CrossRef] [PubMed]

293. Dayana Priyadharshini, S.; Bakthavatsalam, A.K. A comparative study on growth and degradation behavior of $C$. pyrenoidosa on synthetic phenol and phenolic wastewater of a coal gasification plant. J. Environ. Chem. Eng. 2019, 7, 103079. [CrossRef]

294. Leng, L.; Wei, L.; Xiong, Q.; Xu, S.; Li, W.; Lv, S.; Lu, Q.; Wan, L.; Wen, Z.; Zhou, W. Use of microalgae based technology for the removal of antibiotics from wastewater: A review. Chemosphere 2020, 238, 124680. [CrossRef] [PubMed]

295. Peng, F.-Q.; Ying, G.-G.; Yang, B.; Liu, S.; Lai, H.-J.; Liu, Y.-S.; Chen, Z.-F.; Zhou, G.-J. Biotransformation of progesterone and norgestrel by two freshwater microalgae (Scenedesmus obliquus and Chlorella pyrenoidosa): Transformation kinetics and products identification. Chemosphere 2014, 95, 581-588. [CrossRef] [PubMed]

296. Jaiswal, K.K.; Kumar, V.; Vlaskin, M.; Sharma, N.; Rautela, I.; Nanda, M.; Arora, N.; Singh, A.; Chauhan, P. Microalgae fuel cell for wastewater treatment: Recent advances and challenges. J. Water Process Eng. 2020, 38, 101549. [CrossRef]

297. Kusmayadi, A.; Leong, Y.K.; Yen, H.W.; Huang, C.Y.; Dong, C.D.; Chang, J.S. Microalgae-microbial fuel cell (mMFC): An integrated process for electricity generation, wastewater treatment, $\mathrm{CO}_{2}$ sequestration and biomass production. Int. J. Energy Res. 2020. [CrossRef]

298. De-Bashan, L.E.; Bashan, Y. Immobilized microalgae for removing pollutants: Review of practical aspects. Bioresour. Technol. 2010, 101, 1611-1627. [CrossRef]

299. Kumar, K.S.; Dahms, H.-U.; Won, E.-J.; Lee, J.-S.; Shin, K.-H. Microalgae-A promising tool for heavy metal remediation. Ecotoxicol. Environ. Saf. 2015, 113, 329-352. [CrossRef]

300. Aksu, Z.; Tezer, S. Biosorption of reactive dyes on the green alga Chlorella vulgaris. Process Biochem. 2005, 40, 1347-1361. [CrossRef]

301. Daneshvar, N.; Ayazloo, M.; Khataee, A.; Pourhassan, M. Biological decolorization of dye solution containing Malachite Green by microalgae Cosmarium sp. Bioresour. Technol. 2007, 98, 1176-1182. [CrossRef]

302. Mona, S.; Kaushik, A.; Kaushik, C. Biosorption of reactive dye by waste biomass of Nostoc linckia. Ecol. Eng. 2011, 37, 1589-1594. [CrossRef]

303. Mohan, S.V.; Ramanaiah, S.; Sarma, P. Biosorption of direct azo dye from aqueous phase onto Spirogyra sp. I02: Evaluation of kinetics and mechanistic aspects. Biochem. Eng. J. 2008, 38, 61-69. [CrossRef]

304. Bai, X.; Acharya, K. Removal of trimethoprim, sulfamethoxazole, and triclosan by the green alga Nannochloris sp. J. Hazard. Mater. 2016, 315, 70-75. [CrossRef] [PubMed]

305. Hom-Diaz, A.; Norvill, Z.N.; Blánquez, P.; Vicent, T.; Guieysse, B. Ciprofloxacin removal during secondary domestic wastewater treatment in high rate algal ponds. Chemosphere 2017, 180, 33-41. [CrossRef]

306. Villar-Navarro, E.; Baena-Nogueras, R.M.; Paniw, M.; Perales, J.A.; Lara-Martín, P.A. Removal of pharmaceuticals in urban wastewater: High rate algae pond (HRAP) based technologies as an alternative to activated sludge based processes. Water Res. 2018, 139, 19-29. [CrossRef] [PubMed]

307. Xiong, J.-Q.; Kurade, M.B.; Jeon, B.-H. Biodegradation of levofloxacin by an acclimated freshwater microalga, Chlorella vulgaris. Chem. Eng. J. 2017, 313, 1251-1257. [CrossRef]

308. Xiong, J.-Q.; Kurade, M.B.; Jeon, B.-H. Can microalgae remove pharmaceutical contaminants from water? Trends Biotechnol. 2018, 36, 30-44. [CrossRef]

309. Kong, W.; Yang, S.; Guo, B.; Wang, H.; Huo, H.; Zhang, A.; Niu, S. Growth behavior, glucose consumption and phenol removal efficiency of Chlorella vulgaris under the synergistic effects of glucose and phenol. Ecotoxicol. Environ. Saf. 2019, 186, 109762. [CrossRef]

310. Tocher, D.R. Omega-3 long-chain polyunsaturated fatty acids and aquaculture in perspective. Aquaculture 2015, 449, 94-107. [CrossRef]

311. Raja, R.; Coelho, A.; Hemaiswarya, S.; Kumar, P.; Carvalho, I.S.; Alagarsamy, A. Applications of microalgal paste and powder as food and feed: An update using text mining tool. Beni-Suef Univ. J. Basic Appl. Sci. 2018, 7, 740-747. [CrossRef]

312. Gill, I.; Valivety, R. Polyunsaturated fatty acids, part 1: Occurrence, biological activities and applications. Trends Biotechnol. 1997, 15, 401-409. [CrossRef]

313. Pratiwy, F.M.; Pratiwi, D.Y. The potentiality of microalgae as a source of DHA and EPA for aquaculture feed: A review. Int. J. Fish. Aquat. Stud. 2020, 8, 39-41.

314. Martinez-Porchas, M.; Martinez-Cordova, L.R.; Lopez-Elias, J.A.; Porchas-Cornejo, M.A. Bioremediation of aquaculture effluents. In Microbial Biodegradation and Bioremediation; Elsevier: London, UK, 2014; pp. 539-553.

315. Amorim, M.L.; Soares, J.; Coimbra, J.S.d.R.; Leite, M.d.O.; Albino, L.F.T.; Martins, M.A. Microalgae proteins: Production, separation, isolation, quantification, and application in food and feed. Crit. Rev. Food Sci. Nutr. 2020, 1-27. [CrossRef] [PubMed] 
316. Vaudel, M.; Verheggen, K.; Csordas, A.; Ræder, H.; Berven, F.S.; Martens, L.; Vizcaíno, J.A.; Barsnes, H. Exploring the potential of public proteomics data. Proteomics 2016, 16, 214-225. [CrossRef] [PubMed]

317. Fernández-Acero, F.J.; Amil-Ruiz, F.; Durán-Peña, M.J.; Carrasco, R.; Fajardo, C.; Guarnizo, P.; Fuentes-Almagro, C.; Vallejo, R.A. Valorisation of the microalgae Nannochloropsis gaditana biomass by proteomic approach in the context of circular economy. $J$. Proteom. 2019, 193, 239-242. [CrossRef]

318. Gong, Y.; Hu, H.; Gao, Y.; Xu, X.; Gao, H. Microalgae as platforms for production of recombinant proteins and valuable compounds: Progress and prospects. J. Ind. Microbiol. Biotechnol. 2011, 38, 1879-1890. [CrossRef] [PubMed]

319. Shamriz, S.; Ofoghi, H. Expression of recombinant PfCelTOS antigen in the chloroplast of Chlamydomonas reinhardtii and its potential use in detection of malaria. Mol. Biotechnol. 2019, 61, 102-110. [CrossRef]

320. Romay, C.; Gonzalez, R.; Ledon, N.; Remirez, D.; Rimbau, V. C-phycocyanin: A biliprotein with antioxidant, anti-inflammatory and neuroprotective effects. Curr. Protein Peptide Sci. 2003, 4, 207-216. [CrossRef]

321. Zheng, L.-H.; Wang, Y.-J.; Sheng, J.; Wang, F.; Zheng, Y.; Lin, X.-K.; Sun, M. Antitumor peptides from marine organisms. Mar. Drugs 2011, 9, 1840-1859. [CrossRef]

322. Wang, X.; Zhang, X. Separation, antitumor activities, and encapsulation of polypeptide from Chlorella pyrenoidosa. Biotechnol. Prog. 2013, 29, 681-687. [CrossRef]

323. Tejano, L.A.; Peralta, J.P.; Yap, E.E.S.; Panjaitan, F.C.A.; Chang, Y.-W. Prediction of Bioactive Peptides from Chlorella sorokiniana Proteins Using Proteomic Techniques in Combination with Bioinformatics Analyses. Int. J. Mol. Sci. 2019, 20, 1786. [CrossRef] [PubMed]

324. Dong, H.-P.; Williams, E.; Wang, D.-Z.; Xie, Z.-X.; Hsia, R.-C.; Jenck, A.; Halden, R.; Li, J.; Chen, F.; Place, A.R. Responses of Nannochloropsis oceanica IMET1 to long-term nitrogen starvation and recovery. Plant Physiol. 2013, 162, 1110-1126. [CrossRef] [PubMed]

325. Tran, N.-A.T.; Padula, M.P.; Evenhuis, C.R.; Commault, A.S.; Ralph, P.J.; Tamburic, B. Proteomic and biophysical analyses reveal a metabolic shift in nitrogen deprived Nannochloropsis oculata. Algal Res. 2016, 19, 1-11. [CrossRef]

326. Anand, V.; Singh, P.K.; Banerjee, C.; Shukla, P. Proteomic approaches in microalgae: Perspectives and applications. 3 Biotech. 2017, 7, 197. [CrossRef] [PubMed]

327. Lauritano, C.; Ferrante, M.I.; Rogato, A. Marine natural products from microalgae: An-omics overview. Mar. Drugs 2019, 17, 269. [CrossRef] [PubMed] 